\title{
Androgen-induced norepinephrine release in male accessory sex organ smooth muscle growth and differentiation
}

Julie M. Kim

West Virginia University

Follow this and additional works at: https://researchrepository.wvu.edu/etd

\section{Recommended Citation}

Kim, Julie M., "Androgen-induced norepinephrine release in male accessory sex organ smooth muscle growth and differentiation" (1999). Graduate Theses, Dissertations, and Problem Reports. 3132.

https://researchrepository.wvu.edu/etd/3132

This Dissertation is protected by copyright and/or related rights. It has been brought to you by the The Research Repository @ WVU with permission from the rights-holder(s). You are free to use this Dissertation in any way that is permitted by the copyright and related rights legislation that applies to your use. For other uses you must obtain permission from the rights-holder(s) directly, unless additional rights are indicated by a Creative Commons license in the record and/ or on the work itself. This Dissertation has been accepted for inclusion in WVU Graduate Theses, Dissertations, and Problem Reports collection by an authorized administrator of The Research Repository @ WVU.

For more information, please contact researchrepository@mail.wvu.edu. 


\begin{abstract}
Androgen-Induced Norepinephrine Release in Male Accessory Sex Organ Smooth Muscle Growth and Differentiation
\end{abstract}

\author{
Julie M. Kim
}

\author{
Dissertation submitted to the School of Medicine at \\ West Virginia University \\ in partial fulfillment of the requirements \\ for the degree of \\ Doctor of Philosophy \\ in Pharmacology and Toxicology
}

Michael Mawhinney, Ph.D., Chair Charles Craig, Ph.D. Richard Dey, Ph.D. John Durham, Ph.D. William Fleming, Ph.D. Elizabeth Anne Johnson, Ph.D.

Department of Pharmacology and Toxicology 


\section{Acknowledgements}

The members on my committee, particularly Dr. Mawhinney, have been superb advisors and have also become true mentors and friends. I look forward to the continuation and evolution of our relationships.

Much thanks to Dennis Cole, the research assistant in the lab, who was an enormous resource of information and encouragement. I will miss our lunch time conversations.

Thanks also to Drs. David Taylor, Jeff Fedan and Laura Gibson for their assistance and guidance for parts of this research.

Lastly, thanks to my family for knowing when to ignore my stress-related outbursts and when to provide much needed support.

I have had a wonderful time. 
List of Figures

List of Tables

I. Abstract

II. Literature Review

A. Benign prostatic hypertrophy: general background 4

B. Androgen's effect on male accessory sex organs 8

C. Autonomic innervation of the male accessory sex organs 13

D. Androgen's effects on neurotransmission in male accessory sex organs 15

E. Norepinephrine (NE) as a component of cell growth 17

F. NE and transmembrane signaling $\quad 21$

G. Rationale for the use of guinea pig seminal vesicle smooth muscle 25

III. Specific Aims 28

IV. Materials and Methods 30

A. Orchiectomy and hypogastric nerve decentralization 30

B. Dihydrotestosterone and reserpine administration 31

C. Harvesting of seminal vesicle smooth muscle tissue 32

D. NE quantification $\quad 32$

E. DNA quantification $\quad 36$

F. Gel electrophoresis to detect apoptosis 38

G. Seminal vesicle smooth muscle cell cultures $\quad 40$

H. Organ bath electrical field stimulation $\quad 42$

I. $\alpha_{2}$-adrenoceptor characterization and quantification 44

J. Protein kinase C (PKC) analyses 47

K. Statistical analyses $\quad 51$

V. Results 51

A. Androgen in vivo induced norepinephrine release 51

B. NE mediated androgen-induced smooth muscle proliferation in vivo 62

1. Reserpine selectively antagonized smooth muscle proliferation and PKC in androgen-treated animals 62

2. NE stimulated increased smooth muscle cell number via $\begin{array}{ll}\text { the } \alpha_{1} \text {-adrenoceptor } & 74\end{array}$

3. NE did not function anti-apoptotically 80

C. Androgen decreases the $B_{\max }$ of the $\alpha_{2}$-adrenoceptor 84

$\begin{array}{lr}\text { VI. Discussion } & 98\end{array}$

$\begin{array}{lr}\text { VII. References } & 107\end{array}$

Signature page $\quad 123$

Curriculum Vitae 124 

$\mathrm{DHPG} / \mathrm{NE}$, DHPG or NE

5. Time course of measured $\mathrm{NE}$ release in seminal measured directly in prepubertal castrate minced seminal vesicle smooth muscle

7. The effect of 5 -day, $0.25 \mathrm{mg} / \mathrm{kg}$ reserpine treatment on seminal vesicle smooth muscle DNA in prepubertal castrates

8. Effect of norepinephrine-depletion on androgeninduced seminal vesicle proliferation

9. Decentralization had no significant effect on castrate, prepubertal guinea pig seminal vesicle smooth muscle

10. The time course of androgen's effect on PKC and the interaction of reserpine in prepubertal castrate seminal vesicle smooth muscle

11. Relative amounts of $\mathrm{PKC} \alpha$ as measured by chemiluminescence

12. The concentration of fetal bovine serum effected 
13. The effect of plating density ( 1 vs. 6 x $10^{4}$ cell/ 76 well) on $10 \mu \mathrm{M}$ phenylephrine stimulation of seminal vesicle cell culture

14. Cell number increases in low density $\left(1 \times 10^{4}\right.$ cells/well) plated wells

15. The effect of various adrenergic agents on 14-day 79 seminal vesicle smooth muscle cell culture

16. Norepinephrine depletion did not effect DNA in 81 adult seminal vesicle smooth muscle

17. No apoptosis was detected in norepinephrine depleted prepubertal castrates treated with androgen

18. BHT-933 was unable to elicit post-junctional

$\alpha_{2}$-adrenoceptor-mediated contractions in adult normal guinea pig seminal vesicle smooth muscle

19. An example of electrically field stimulated 87 contractile tracings from isolated seminal vesicle smooth muscle tissues

20. ${ }^{3} \mathrm{H}-\mathrm{RX} 821002$ binding rate and protein dependence of ${ }^{3} \mathrm{H}-\mathrm{RX} 821002-\mathrm{binding}$ in adult normal guinea pig seminal vesicle smooth muscle

21. Saturation binding curves and Scatchard-Rosenthal plots for the $\alpha_{2}$-adrenoceptor using ${ }^{3} \mathrm{H}-\mathrm{RX} 821002$ in normal adult guinea pig seminal vesicle smooth muscle

22. Number of $\alpha_{2 D}$-binding sites ( $B_{\max }$ ) in seminal 96 vesicle smooth muscle among various treatment groups. $\mathrm{B}_{\max } / \mathrm{NE}$ release is in parentheses 
1. 24 hours reserpine dose response in prepubertal oil-treated castrate controls

2. Comparison of IC50's and affinity $\left(K_{i}\right)$ of drugs for the $\alpha_{2}$-adrenoceptor, using $5 \mathrm{nM}{ }^{3} \mathrm{H}-\mathrm{RX} 821002$ in adult normal guinea pig seminal vesicle smooth muscle

3. Ratio of $K_{i}$ of competitor to respective $K_{d}$ of RX821002 in experiments done in guinea pig seminal vesicle smooth muscle compared to other tissues with $\alpha_{2 D}-$ adrenoceptors 


\section{Abstract}

Androgen-induced norepinephrine release in male accessory sex organ smooth muscle growth and differentiation. Julie M. Kim

The goal of this research was to determine the role of norepinephrine (NE) in androgen-dependent pubertal proliferation and adult terminal differentiation in normal male accessory sex organ smooth muscle. The guinea pig seminal vesicle served as a model as its unique anatomy allowed clean harvest of smooth muscle without epithelium. Androgen significantly increased in vivo DNA synthesis, total DNA, and NE release and down-regulated protein kinase $\mathrm{C}(\mathrm{PKC})$ in prepubertal seminal vesicle smooth muscle (SVSM) relative to prepubertal orchiectomized controls. High performance liquid chromotography quantified $\mathrm{NE}$ release as an increased concentration of 1) endogenous NE-metabolite, 3,4-dihydroxyphenolglycol per NE, and 2) NE in vitro SVSM minces. Binding studies using [ $\left.{ }^{3} \mathrm{H}\right] \mathrm{RX} 821002$, an $\alpha_{2}$-adrenoceptor antagonist, showed a concurrent four-fold decrease in $\alpha_{2}$-adrenoceptor concentration, indicating reduced feedback as a potential mechanism for the increase in norepinephrine release. In vivo $\mathrm{NE}$-depletion of $\geq 99 \%$ by reserpine selectively antagonized the androgen-induced increases in SVSM-DNA 
(measured spectrofluorophotometrically) and protein kinase C (PKC) down-regulation (measured by $\gamma\left[{ }^{32} \mathrm{P}\right]$ ATP transfer). Gel electrophoresis detected no apoptosis, supporting other evidence that cell number is proliferation-dependent. Cell culture experiments demonstrated that SVSM $\alpha_{1}$-adrenoceptors mediated the proliferative response to NE. Functional $\alpha_{1}-$ adrenoceptor expression, exhibited by electrical field stimulation of SVSM neurons, correlated with the onset of androgen-induced proliferative response.

In terminally differentiated adult SVSM, elevated NE release and decreased $\alpha_{2}$-adrenoceptor concentration were maintained from puberty and developed androgen-resistance. PKC, however, returned to prepubertal castrate control levels (Mariotti et al., 1992). Androgen withdrawal combined with $\mathrm{NE}$ depletion caused no reduction in adult SVSM-DNA relative to adult castrates. These findings suggest that while increased $\mathrm{NE}$ release plays an obligatory role in pubertal SVSM proliferation, NE release becomes uncoupled from the mitogenic response at or before PKC stable activation in adulthood.

Human benign prostatic hypertrophy (BPH) is a fibromuscular neoplasia. The data presented here suggest BPH may be due to defective uncoupling between sustained, 
androgen-induced $\mathrm{NE}$ release and PKC activation. New pharmacological therapies for $\mathrm{BPH}$ can be envisioned based on either antagonizing the reduction in presynaptic $\alpha_{2}-$ adrenoceptors to prevent increased $\mathrm{NE}$ release or inducing PKC resistance to generate the normal amitotic state. 


\section{Literature Review}

\section{A. Benign Prostatic Hypertrophy: General Background}

Benign prostatic hypertrophy (BPH) is primarily a stromal neoplasia of the innermost aspect of the prostate. The origin of the neoplasia is confined primarily to periurethral tissue around the verumontanum, in proximity to the cylindrical urinary sphincter that arises from the bladder neck (Reischauer, 1925; Deming and Wolf, 1939; Pradhan and Chandra, 1975; McNeal, 1978). Glandular epithelial tissue comprises approximately 20-30\% of BPH mass, whereas 70-80\% is fibromuscular (Rohr and Bartsch, 1980). Although the cause of BPH is not understood, the adenoma is androgen and age dependent (Huggins and Stevens, 1940; Wu and Gu, 1987).

By examining random specimens at autopsy, benign prostatic hypertrophy $(\mathrm{BPH})$ has been found to begin as a microscopic, non-symptomatic nodule as early as age 25-30 years of age when it has a prevalence of $10 \%$. With advancing age, histological prevalence of BPH rises such that by age $60,70 \%$ of men are effected and by age $80,90 \%$ of men have histologically identifiable BPH (Arrighi et al., 1991). There is a lag period of approximately 5 years in which $50 \%$ of microscopic BPH develops into macroscopic 
$\mathrm{BPH}$ that can be palpated through digital rectal examination (Isaacs and Coffey, 1989). Of these macroscopic nodules, half will become clinically significant, meaning that only 25\% of men with histologically identifiable BPH eventually develop clinically relevant pathology (Lytton et al., 1969). However, on the basis that 25\% of all men with histologically identifiable BPH will need therapeutic intervention, it appears that the probability that a 50year-old man will undergo medical treatment for $\mathrm{BPH}$ in his lifetime is estimated to be 35\% (Glynn et al., 1985). The high incidence of this neoplasia makes the development of future pharmacological prophylactics for BPH prevention a practical concept.

At clinical presentation of sympomatic disease, the enlarged adenoma displaces the normal organ and weighs between 60 and 100 grams, although weights of up to 200 grams have been seen. These nodular enlargements encroach upon the walls of the urethra, contributing to a set of symptoms collectively termed clinical BPH. Clinical BPH symptoms include: 1) urethral compression causing difficulty in urination and 2) urinary retention causing subsequent bladder distension and hypertrophy. These secondary effects can then lead to tertiary complications such as urinary tract infections, cystitis, renal 
infections, and decreased bladder continence due to thinning of the bladder musculature. The severity of clinical, symptomatic BPH does not correlate with the size of the adenomatous mass. Additional pathologies may be required for the presentation of clincally significant disease. For example, environment and genetic predisposition (Ekman, 1989), lymphocytic infiltration (Kohnen and Drach, 1979), infarcts (Franks, 1975), nonandrogenic testicular factors (Sutkowski et al., 1993), the stromal-epithelial interaction (Cunha, 1973), and a variety of hormones and neurotransmitters have been suggested to contribute to the development of BPH. None of the above, however, have been shown to be directly responsible for the development of adenomatous, smooth muscle cell BPH as will be the focus of the research presented here.

By 1989, the large number of men with clinical BPH made procedures such as the transurethral resection of the prostate (TURP) the second most common surgical procedure, following cataract removal, for men 65 years of age and older, costing the health care system more than five billion dollars (Graversen et al., 1989). This dollar amount includes only surgical treatment of $\mathrm{BPH}$ and overlooks widely prescribed medical treatments such as $5 \alpha-$ 
reductase inhibitors (finasteride), $\alpha_{1}$-adrenoceptor antagonists (terazosin and doxazosin) and the newer, less well-evaluated therapies such as thermoablation and stents.

Unfortunately, no treatment regimen has been highly satisfactory to the patient. The surgical treatments, TURP and open prostatectomy, represent the most effective form of treatment with $75-96 \%$ of patients reporting symptom improvement and only a $2.2 \%$ reoperation rate (Oesterling, 1995). Surgery also has the highest rate of severe complications such as impotence in 5-10\% and urinary incontinence in up to 4\% (Geller et al., 1995).

None of the various pharmacological therapies cure the disease, but rather help to alleviate obstruction by different mechanisms. While the 5 - $\alpha$-reductase inhibitor, finasteride, inhibits epithelial growth, the peak onset of effect is 6-12 months after treatment. Thirty percent of men received some benefit as measured by symptom scoring (Geller et al., 1995). However, the change in symptom score is only marginally different from placebo (2.6 vs 1 for placebo) (Lepor et al., 1996). Side effects include impotence and decreased libido. $\alpha_{1}$-adrenoceptor antagonists reduce sympathetic tone around the bladder neck to improve urinary outflow in 60-80\% of patients within $4-6$ weeks of 
treatment initiation. However, $10 \%$ of patients suffer adverse effects such as hypotension and headache (Jonler et al., 1994). All of the current pharmacological therapies must be maintained chronically, since they only relieve secondary symptoms in reversible fashion.

By the year 2000, forty million men will begin to reach middle age (Bouvier and DeVita, 1991). They represent the largest population in history that will face the problems of BPH. (They also represent an enormous market for pharmaceutical companies.) There is a definite need to develop more effective treatments for clinical BPH, and even to ultimately develop a therapy for prevention of the adenomatous growth.

\section{B. Overview of Androgen Effects on Male Accessory Sex Organs}

Androgens effect a wide variety of target tissues such as external and internal reproductive structures, sebaceous glands, muscle and even the peripheral and central nervous systems. Androgenic effects range from the morphogenesis of the male phenotype (Jost, 1953) to excitatory or 
maintenance actions on cellular growth and secretion via androgen receptor-mediated induction of gene transciption (Price and Williams-Ashman, 1961; Liao and Fang, 1970; Roy and Chatterjee, 1995).

While much of the recent research of androgen action has focused on genomic effects, nongenomic effects of androgens at physiological concentrations have also been identified within reproductive tissues. These nongenomic effects occur too rapidly to be compatible with changes in mRNA and protein synthesis. In general these non-genomic effects have been implicated in signal transduction events such as changing intracellular calcium concentrations and effecting chloride flux in rat Sertoli cells (Revelli et al., 1998). Androgens may also function to modulate biochemical reactions within some cells by serving as coenzymes for the transfer of hydrogen between NADPH and NAD (Talalay and Williams-Ashman, 1958).

Testosterone can diffuse passively into cells and can either bind directly to the androgen receptor or can be reduced to $5 \alpha$-dihydrotestosterone (DHT) by reduction with $5 \alpha$-reductase (Farnsworth and Brown, 1963; Bruchovsky and Wilson, 1968). DHT can also bind the androgen receptor and will do so with greater affinity and stability than testosterone itself (Krieg et al., 1976). The gene coding 
for the androgen receptor is located on the $\mathrm{X}$ chromosome and has been cloned (Lubahn et al., 1988). $5 \alpha-$ dihydrotestosterone (DHT) binds the steroid binding domain of the receptor. Chaperone proteins such as heat shock proteins then dissociate from the receptor, enabling the activated receptor to dimerically bind DNA within the nucleus at a specific DNA enhancer sequence called the androgen-responsive element (Lindzey et al., 1994). Testosterone also binds the receptor but has a diminished effect on the tissue compared to DHT (Wenderoth et al., 1983; Geller, 1990). Upon binding to the androgenresponsive element, the androgen receptor then can modulate transcriptional activity ultimately effecting morphogenic and other growth-promoting and stimulatory processes in target tissues.

Most research on male accessory sex organs have focused on androgen regulation of the epithelium. However, the clinical importance of the fibromuscular stroma in BPH and the role of the mesenchyme in embryonic development of male accessory sex organ (Cunha, 1973) has begun to focus attention on the hormonal regulation of smooth muscle. After castration, the rat ventral prostate epithelial cells showed a $92 \%$ reduction in number and an $85 \%$ decrease in cell size. The fibromuscular stroma was also effected but 
to a lesser degree, showing a 39\% decrease in cell number and a 23\% decrease in cell size. Exogenous testosterone replacement reversed these changes (DeKlerk and Coffey, 1978). In this same organ, intra-acinar stromal cells which may be smooth muscle cells, were unlike other prostatic cells in that castration and androgen replacement did not affect cell number (English et al., 1985).

Relevant to the focus of the research presented here, were prior studies of androgen action on male accessory sex organ fibromuscular stroma. Mariotti et al. (1992) examined the effects of castration and androgen replacement on DNA in prepubertal and adult guinea pig seminal vesicle smooth muscle. Castration of prepubertal guinea pigs prevented the postnatal development of the seminal vesicle smooth muscle number as measured by DNA. This development was shown to be androgen dependent as the treatment of these prepubertal castrates with dihydrotestosterone would restore smooth muscle development. Adult smooth muscle, however, appeared to be terminally differentiated. Neither androgen depletion (castration) nor repletion had any effect on adult smooth muscle cell number which were similar to observations recorded earlier by English et al. (1985). Dihydrotestosterone's actions on the seminal 
vesicle smooth muscle have been shown to be androgen receptor mediated (Neubauer and Mawhinney, 1981).

Male accessory sex organs also contain estrogen receptors which are concentrated in the fibromuscular stroma (Belis et al, 1976; Neubauer and Mawhinney, 1981). Estrogen treatment of castrate male guinea pigs induced growth in smooth muscle tissue via an estrogen receptor dependent mechanism (Mariotti and Mawhinney, 1981; Neubauer et al.,1989). However, several lines of evidence have indicated that estrogen is not of physiological significance in this growth (Neubauer et al., 1981). However, intraneuronal aromatization of testosterone to estradiol in the medial preoptic area of male rats is required for normal androgen effects on male sexual behavior, and both dihydrotestosterone and estradiol are required to generate normal virilization of this neural site (Christensen and Clemens, 1975). The extent to which aromatization is involved in androgen action in peripheral neurons is questionable. However, neurosteroids, formed de novo in neurons, have been identified in both central and peripheral neurons (Jung-Testas et al., 1989; Melcangi et al., 1990) and may modulate neurotransmission either directly or through gene transcription. The degree of 
estrogen receptor involvement in male accessory sex organ neurotransmission remains to be defined.

\section{Autonomic Innervation of the Male Accessory Sex Organs}

In the human, the preganglionic sympathetic innervation of the prostate is from the last 3 thoracic (T10, T11 and T12) and first 2 lumbar (L1 and L2) segments of the spinal cord. These form 2 pathways, the superior hypogastric plexus and the continuation of the pelvic sympathetic trunks. The preganglionic parasympathetic innervation comes from the second through fourth sacral spinal nerves to form the pelvic splanchnic nerves which join other sympathetic hypogastric nerves to form the inferior hypogastric plexus. The sympathetic and parasympathetic nerves form what is called the pelvic plexus which innervates the pelvic organs as well as the external genitalia.

The smooth muscle of the guinea pig seminal vesicle is largely comprised of circularly oriented smooth muscle cells with an additional longitudinal layer toward the proximal, urethral end. Based on light microscopy, both smooth muscle layers are abundantly innervated with 
catecholamine-containing nerves, which are particularly concentrated at the base of the organs. The sympathetic adrenergic innervation originates from long preganglionic hypogastric neurons which synapse with short postganglionic neurons whose cell bodies are in the adventitia of the seminal vesicle (Al-Zuhair et al., 1977). Cholinesterasecontaining nerves are rarely encountered in the outer layer, but can be identified in modest amounts in the circular inner layer. The submucosa and epithelia are rich in cholinesterase-containing nerves, and catecholaminecontaining nerves are rare (Al-Zuhair et al., 1975). Because the epithelium is cholinergically innervated and has minimal to no adrenergic fibers, this tissue can therefore serve as an indicator of androgenic responses that have no direct link to cellular adrenergic innervation.

By using agonists and antagonists in vas deferens, a biphasic contractile response to electrical field stimulation has been defined. This initial contraction has been described as being ATP-mediated in the guinea pig vas deferens (Burnstock et al., 1972; Westfall and Stitzel, 1978). The latter component of the contractile response is mediated by the post-junctional $\alpha_{1}$-adrenoceptor which was abolished by prazosin in the rat vas deferens. Rauwolscine 
enhanced the contractile response, indicating the existance of the pre-junctional $\alpha_{2}$-adrenoceptor which mediates norepinephrine feedback (Brown et al., 1983).

Prostatic $\alpha_{1}$-adrenoceptors are found in the smooth muscle. At this time, evidence supports the existence of three $\alpha_{1}$-adrenoceptor subtypes, A, B and D as well as subtypes with high affinity $\left(\alpha_{1 \mathrm{H}}\right)$ and low affinity $\left(\alpha_{1 \mathrm{~L}}\right)$ to prazosin, which appear to be variants of the $\alpha_{1 \mathrm{~A}}-$ adrenoceptors (Andersson et al., 1997). Norepinephrinefeedback-mediating $\alpha_{2}$-adrenoceptors also exist in several subtypes, A, B, C and D. The A and D subtypes are considered to be species homologues (Bylund, 1995).

\section{Androgen Effects on Neurotransmission in Male Accessory Sex Organs}

Several studies have examined the effect of puberty on the development of neurotransmission in the rat vas deferens. The post-natal development of $\alpha_{1}$-adrenoceptor mediated contraction in the rat vas deferens coincided with the large increase in endogenous androgen production at 
puberty (Swedin, 1972). Rauwolscine-induced enhancement of electrically field stimulated rat vas deferens also did not occur until the rat was pubertal (MacDonald and McGrath, 1984). However, because of the lack of a prepubertal $\alpha_{1}-$ mediated response, it was not possible to determine whether the function of the $\alpha_{2}$-adrenoceptor was also androgen dependent.

More studies have linked androgens to the modulation of adult adrenergic neurotransmission in target tissue smooth muscle. Twelve weeks after the castration of adult Wistar rats, the adrenergic component of the contractile response to electrical field stimulation was lost. Spontaneous contractions that were not suppressed by adrenergic antagonists, also developed post-castration. Exogenous testosterone replacement daily for ten days partially reversed this castration-induced loss of the adrenergic contractile response and abolished the spontaneous contractions (MacDonald and McGrath, 1980). Total activities of tyrosine hydroxylase, the rate-limiting enzyme of norepinephrine biosynthesis, as well as dopaminebeta-hydroxylase, which catalyzes the last step of norepinephrine synthesis were also shown to decrease per pair of rat vasa deferentia after castration. Neither castration nor androgen repletion effected changes in 
enzyme concentrations. Norepinephrine content per pair of rat vasa deferentia also fell but as was observed with the contractile response, testosterone replacement reversed these decreases such that norepinephrine returned to control levels (Bustamante et al., 1989).

\section{E. Norepinephrine as a Component of Cell Growth in Male Accessory Sex Organ Smooth Muscle}

It is clinically established that $\alpha_{1}$-adrenergic antagonists reduce smooth muscle tone and thus relieve some of the obstructive symptoms of $\mathrm{BPH}$, but any impact on smooth muscle cell growth in human prostatic smooth muscle has not been formally evaluated. However, laboratory research has demonstrated that catecholamines may play a significant role in the proliferation of a variety of cells including smooth muscle.

In 1989, Marino et al. established that norepinephrine enhanced cellular proliferation in dividing fetal rat cardiocytes. The next year, it was reported that low passages of subconfluent primary rat aorta cultures exhibited an increase in DNA synthesis in the presence of low concentrations of norepinephrine ( $1 \mathrm{nM}$ ) which was 
mediated through $\alpha_{1}$-adrenoceptors (Nakaki et al., 1990). On the other hand, a high concentration of norepinephrine (10 $\mu \mathrm{M})$ inhibited DNA synthesis via $\beta_{2}$-adrenoceptors, as confirmed with $\beta_{2}$-adrenoceptor agonist, isoproterenol (Nakaki et al., 1990). Later studies on primary cultures of rat aortic smooth muscle showed that epinephrine-induced increases in proliferation rate could be inhibited by $\alpha_{1}-$ adrenoceptor antagonist, prazosin, but not by $\alpha_{2}-$ nor $\beta-$ adrenoceptor antagonists, yohimbine or propranolol (Mimura et al, 1995). Thus it was confirmed that catecholamineinduced proliferation was an $\alpha_{1}$-adrenoceptor effect.

This enhanced proliferation is not limited to cardiocytes and the vasculature. Hepatocyte cultures also showed proliferative effects due to catecholamines. Epinephrine and norepinephrine were found to accelerate the entry into $S$ phase but inhibit cells if added in late $\mathrm{G}_{1}$. Phenylephrine accelerated proliferation, but at a lower rate (Refsnes et al., 1992). It has also been shown that $\alpha_{1}$-receptor blockade by prazosin abolished the twenty-four hour peak of DNA synthesis in regenerating rat liver post partial hepatectomy (Cruise et al., 1987).

The relationship between catecholamines and cell proliferation has also been studied in atherosclerosis. 
Plasma adrenaline and noradrenaline levels in patients with or without arteriosclerosis significantly and positively correlated with the severity of vascular smooth muscle thickening (Hauss et al., 1990). It has also been shown that prazosin and urapidil, $\alpha_{1}$-adrenoreceptor antagonists, orally administered to rats whose carotid arteries were experimentally injured with a balloon catheter reduced the formation of neointima. The formation of neointima, as measured by DNA analysis, was significantly reduced in both groups of rats, while the urapidil rats also showed significant reductions in growth as morphometrically measured in terms of area on histological cross-section. These reductions in DNA and in cross-sectional area were dose-dependent (Fingerle et al., 1991).

The role of catecholamines has been studied not only in cellular proliferation, but also in apoptosis. This has resulted in some potentially conflicting hypotheses about the role of norepinephrine. Twenty-four hour norepinephrine $(10 \mu \mathrm{M})$ exposure in rat ventricular myocytes in vitro was shown to decrease the number of viable myocytes by 35\% and to increase the percentage of apoptotic cells two-fold (Communal et al., 1998). Mouse spleen cells and macrophages were also shown to undergo norepinephrineinduced apoptosis in a dose-dependent manner (Josefsson et 
al., 1996). Another laboratory found that it was 3,4dihydroxyphenylglycolaldehyde (DOPGAL), a monoamine oxidase A metabolite of norepinephrine, that induced apoptosis in PC-12 (rat pheochromocytoma) cells, a model for adrenergic neurons (Burke et al., 1997 and 1998). The metabolite DOPGAL, but not norepinephrine itself, was able to induce apoptosis. Communal et al. (1998) and Josefsson et al. (1996), cited above, did not examine norepinephrine metabolites in their studies. On the opposing side is research showing that norepinephrine reverses the apoptotic effect of activin $A$ in rat hepatocyte cultures (Zhang et al., 1996), showing that more work needs to be done to determine what is truly occurring.

While evidence has been accrued on catecholamineenhanced proliferation in organ systems such as the vascular smooth muscle and hepatocytes, almost no work has been done in the field of accessory sex organs such as the prostate. Determining what role catecholamines play in accessory sex organ smooth muscle growth could provide important clues in the understanding and treatment of associated diseases such as BPH. 


\section{F. Norepinephrine and Transmembrane Signaling via $\alpha_{1}-$ Adrenoceptors of Protein Kinase C}

Activation of $\alpha_{1}$-adrenoreceptors by norepinephrine is known to activate a G-protein which then stimulates phospholipase C (PLC) (Das, 1993). PLC cleaves phosphoinositol-bisphosphate $\left(\mathrm{PIP}_{2}\right)$ which is a phosphorylated derivative of phosphatidylinositol, a phospholipid in cell membranes. PIP $_{2}$ cleavage results in inositol 1,4,5-triphosphate which releases calcium from the endoplasmic reticulum and activates calcium channels (Larsson et al., 1984). The other product of $\mathrm{PIP}_{2}$ cleavage is diacylglycerol (DAG) which in turn temporarily activates protein kinase $\mathrm{C}(\mathrm{PKC})$. The temporary activation of $\mathrm{PKC}$ results in translocation of the enzyme from the cytoplasm to the plasma membrane (Kishimoto, et al., 1980; Kraft and Anderson, 1983).

Phorbol esters are often called tumor promoters because of their ability to enhance cellular proliferation leading to tumor formation. Phorbol esters such as PMA structurally mimic diacylglycerol (DAG). DAG produces only temporary association of PKC with the membrane due to activation of sphingomyelinase (Kolesnick, 1987). Sphingomyelinase activation can result in increased 
concentrations of sphingosine which compete for the regulatory unit of $\mathrm{PKC}$ and thus inhibit $\mathrm{PKC}$ activity (Hannun et al., 1986). However, relative to DAG, PMA can stablely activate PKC which may be due in part to its inability to activate sphingomyelinase (Kolesnick, 1987). Stable activation of PKC was demonstrated in 1988 by the addition of PMA to cultured neonatal rat cardiomyocytes. A five minute exposure to PMA doubled total PKC activity as compared to the control. By forty-eight hours, PMA treatment of these neonatal cardiomyocytes resulted in a down-regulation of total PKC activity to just 3\% of control (Henrich and Simpson, 1988). It is thought that this downregulation is not a decrease in synthesis, but a result of increased degradation by calpain, a calcium-dependent protease (Young et al., 1987). To summarize, unlike temporary activation by diacylglycerol, phorbol esters lead to stable activation of $\mathrm{PKC}$, followed by cellular PKC depletion and subsequently to cellular proliferation (Hansen et al., 1990; Brooks et al., 1991). Similarly to PMA down-regulation of $\mathrm{PKC}$, activation of $\alpha_{1}$-adrenoreceptors with $10 \mu \mathrm{M}$ norepinephrine for 4 hours in vascular smooth muscle cell culture down-regulated PKC (Hu et al., 1992). Although the decrease in PKC with prolonged $\alpha_{1}$-adrenoceptor activation has not been directly related to 
smooth muscle growth, there are many studies linking $\alpha_{1}-$ adrenergic effects to proliferation. With this in mind, it becomes a possibility that prolonged $\alpha_{1}$-adrenoreceptor activation and down-regulated PKC are dependent upon one another in association with proliferation. This would fit well with the hypothesis of this research linking prepubertal, androgen-induced increased norepinephrine release with, PKC down-regulation and male accessory sex organ smooth muscle proliferation.

It is necessary to recognize the complexity within the PKC superfamily. Molecular cloning has identified and characterized eleven PKC isoforms and has established that PKC is a multigene family. However, which PKC isozyme is responsible for smooth muscle cell proliferation is still being examined. PKC isozymes $\alpha, \beta, \delta, \varepsilon, \gamma$, and $\zeta$ were studied in cultured porcine aortic vascular smooth muscle cells. PKC $\alpha$ and PKCE were implicated as possible mediators of $\mathrm{G}_{1} / \mathrm{S}$ cell cycle inhibition with $\mathrm{PKC} \alpha$ predominating. PKC $\alpha$ down-regulated completely with PMA. PKCE also downregulated in response to $\mathrm{PMA}$, although not completely (Sasaguri et al., 1993). A later study using cultured rat aortic vascular smooth muscle cells, quantified PKC isoforms $\alpha, \beta$ and $\gamma$, and found $\operatorname{PKC} \alpha$ was the only significant 
isoform associated with proliferation, also by downregulation (Haller et al., 1995).

Reduced amounts of total PKC activity (Mariotti et al., 1992) and enhanced calpain activation (Gerbrosky et al., 1997) also occur in response to androgen-induced accessory sex organ smooth muscle proliferation (Mariotti et al., 1992). Prepubertal guinea pigs showed a doubling of DNA and a drop in PKC in their seminal vesicle smooth muscles in contrast to their adult counterparts. Adult guinea pigs showed no changes in $\mathrm{PKC}$, calpain, or in DNA in response to androgen. However, normal adult seminal vesicle smooth muscle which failed to proliferate with androgen treatment, still continued to hypertrophy in response to androgen, reflecting a selective loss in proliferative ability in which PKC is resistant to changes produced by androgen. What remains to be explored is the mechanism and potential link of PKC activation and subsequent depletion to androgen regulation of neurotransmission in male accessory sex organ smooth muscle. 


\section{G. Rationale for the Use of Guinea Pig Seminal}

\section{Vesicle Smooth Muscle}

Benign prostatic hypertrophy is a smooth muscle neoplasia. The goal of the research presented here is to understand the normal mitogenic and terminal differentiation mechanisms of androgen-dependent male accessory sex organ smooth muscle cells. Understanding this could ultimately be used to develop improved treatment and preventative therapies to pharmacologically interfere with the growth of the adenoma and the clinical presentation of $\mathrm{BPH}$.

Unfortunately, a good animal model for the study of $\mathrm{BPH}$ does not exist and it has not been possible to establish androgen-sensitive culture systems for normal or neoplastic smooth muscle cells. It should be recognized that the true human prostate gland (the anterior, posterior and lateral lobes) do not develop BPH. It is the periurethral, fibromuscular stroma that is the origin the adenoma (Reischauer, 1925; Pradhan and Chandra, 1975). Rodent male accessory sex organs do not exhibit spontaneous prostatic hyperplasia. The hormonal induction of hypertrophy has never been achieved in the rat prostate, and most mice strains show only marginal diethylstilbestrol 
induction of prostatic hyperplasia (Fingerhut and Veenema, 1966). While aging dogs develop $\mathrm{BPH}$, the neoplasia is primarily a diffuse parenchymal hyperplasia. Dog prostate also does not show nodular growth that compresses surrounding normal tissue, as seen in man (Moore, 1944). Implants and xenografts of various prostate tissues into hosts have also been tried in attempts to induce abnormal growth. Implantation of intact fetal urogenital sinus into the ventral prostate gland of athymic mice caused a 10-20 fold overgrowth within 4-9 weeks (Chung et al., 1984), but it has been difficult to quantify changes due to growth of the embryonic specimen versus the host response. Human BPH tissue xenografts in nude mice have been explored. But these xenografts are difficult to maintain, show gradual atrophy and increasing squamous metaplasia and have not been successfully maintained for longer than 16 weeks (Debiec-Rychter et al., 1994). Given the absence of a definitive animal model for human $\mathrm{BPH}$, androgen-dependent proliferation and differentiation of normal accessory sex organ smooth muscle was studied. The long term goal was to develop a hypothesis for the potential etiology and treatment of the human neoplasia of the periurethral fibromuscular stroma. 
The guinea pig seminal vesicle was employed in this investigation because of its unique anatomy • Architecturally, the seminal vesicle is a cylindrical tube, with a distinct inner epithelial layer and an outer smooth muscular compartment. The smooth muscle can be quickly separated from the epithelium, leaving pure smooth muscle specimens which can be employed in a variety of experimental analyses. This preparation was initially employed by Levey and Szego (1955) .

The normal guinea pig seminal vesicle smooth muscle shows a prepubertal, androgen-sensitive state in which DNA in smooth muscle cells increase, and an adult terminally differentiated state that is selectively resistant in this response to androgen (Mariotti et al., 1992). Comparing the prepubertal state in guinea pig seminal vesicle in which DNA increases in response to androgen against the adult which is resistant to androgen-induced proliferation could uncover the mechanisms for normal accessory sex organ smooth muscle growth and terminal differentiation. Defects in the normal terminal differentiation process for smooth muscle tissue may prove to be an essential component in the proliferation of accessory sex organ fibromuscular stroma leading to human $\mathrm{BPH}$. 


\section{Specific Aims}

The long term goal of this research is to understand norepinephrine's role in the androgen-mediated proliferation of male accessory sex organ smooth muscle and to ultimately use this knowledge to develop possible treatments and preventative therapies of benign prostatic hypertrophy (BPH). The working hypothesis of this research is that androgen-dependent prepubertal proliferation of male accessory sex organ smooth muscle is due to an androgen-dependent increase in norepinephrine release and down-regulation of $\mathrm{PKC}$. With this in mind, studies were done to determine physiological relevance of norepinephrine in the development of seminal vesicle smooth muscle, then the mechanism by which norepinephrine release occurred, using both ex vivo and in vitro experimental designs.

A. Specific Aim 1: Determine if androgen in vivo induces the release of norepinephrine in seminal vesicle smooth muscle in association with proliferation and is resistant in terminal differentiation. 
B. Specific Aim 2: Determine the role of norepinephrine as a mediator of growth in androgen-induced proliferation of seminal vesicle smooth muscle.

1. Determine whether reserpine at maximal norepinephrine-depleting doses in vivo selectively antagonizes seminal vesicle smooth muscle proliferation and PKC down-regulation in androgentreated animals.

2. Determine if norepinephrine in vitro stimulates increases in cell number of seminal vesicle-derived smooth muscle cells via $\alpha_{1}$-adrenoceptors.

3. Determine if norepinephrine may function antiapoptotically in seminal vesicle smooth muscle cells to effect changes in cell number.

C. Specific Aim 3: Determine whether the androgeninduced increase in norepinephrine release is due to a significant reduction in the pre-synaptic feedback inhibition of norepinphrine release. 


\section{Materials and Methods}

A. In Vivo Orchiectomy and Hypogastric Nerve Decentralization

Adult male Hartley guinea pigs (Hilltop) were inhalationally anesthetized with metafane and underwent scrotal route castration. The skin incisions were closed using stainless steel surgical staples. Prepubertal, 5-7 day old, male Hartley guinea pigs (Hilltop) were inhalationally anesthetized with ether and underwent castration by midline abdominal incision. In some animals, hypogastric nerve decentralization was done simultaneously with the castration by severing the hypogastric nerve within the intestinal mesentery. The hypogastric nerve was positively identified prior to surgery with preliminary in situ electrical stimulation of the hypogastric nerve resulting in seminal vesicle contraction. To close, abdominal walls were sutured with silk thread, then the skin was stapled together. 
B. Dihydrotestosterone, Estradiol, Testosterone, and Reserpine Administration

After a ten day recovery period, $10 \mathrm{mg} / \mathrm{kg}$ of $5 \alpha-$ androstan-17ß-ol-3-one, aka. dihydrotestosterone (DHT) (Sigma), $0.01 \mathrm{mg} / \mathrm{kg}$ of estradiol benzoate ( $\left.\mathrm{E}_{2} \mathrm{~B}\right)$ (Sigma), or $10 \mathrm{mg} / \mathrm{kg}$ testosterone (Sigma) dissolved in peanut oil (Planters), was administered subcutaneously.

These doses were chosen since it was previously established that this dose was the maximally effective dose to observe seminal vesicle smooth muscle growth in the guinea pig (Neubauer and Mawhinney, 1981). Steroids were administered for a minimum of one week since one week was the time period established previously to show a significant increase in DNA levels and DNA synthesis (Mariotti et al., 1992).

Control groups received subcutaneous peanut oil only. Reserpine (Sigma) was freshly prepared on each day of use. The varying concentratrations of reserpine were first dissolved in $100 \mu \mathrm{l}$ benzyl alcohol (Fisher) and $13.67 \mathrm{mg}$ citric acid monohydrate (Sigma) with slight heat. $500 \mu l$ propylene glycol (Sigma) was then added and mixed. Water 
was used to q.s. to $5 \mathrm{ml}$. Reserpine was then administered intraperitoneally.

Control groups received intraperitoneally administered vehicle only.

C. Harvesting of Seminal Vesicle Smooth Muscle Tissue

All guinea pigs were anesthetized by ether inhalation then euthenized via cervical dislocation. Seminal vesicles were immediately removed at the bifurcation and longitudinally opened. Epithelia were carefully separated by manual removal with a blunt scalpel, leaving clean smooth muscle intact. Both epithelia and smooth muscle tissues were weighed.

D. Quantification of Norepinephrine Release

Norepinephrine release was measured both directly in smooth muscle minces and indirectly ex vivo by DHPG/NE ratios in samples from guinea pigs treated in vivo. NE and DHPG were quantified by HPLC. 


$$
\text { 3,4-dihydroxyphenylglycol (DHPG) is the primary }
$$

norepinephrine metabolite found within the rat vas deferens (Tarlov and Langer, 1971). A previous study to determine the metabolite spectrum in guinea pig seminal vesicle smooth muscle indicated that DHPG was the predominant metabolite and could be clearly detected using the method described here (Johnson, 1996). Previous studies established that DHPG/NE ratio indicated norepinephrine release (Graefe et al., 1972; Cubeddu et al., 1974).

Spontaneous release of $\left[{ }^{3} \mathrm{H}\right]$ norepinephrine was found to yield primarily 3,4-dihydroxyphenylglycol in the rat vas deferens (Graefe et al., 1972). Electrical field stimulation of the rat vas deferens also yielded 3,4-dihydroxyphenylglycol (Cubeddu et al., 1974). By using cocaine, it was determined that the 3,4-dihydroxyphenylglycol formation was the result of presynaptic metabolism by monoamine oxidase of the released norepinephrine which was recaptured by adrenergic nerve endings (Langer and Enero, 1974). Storage-inhibiting agents like reserpine will also increase the amount of 3,4-dihydroxyphenylglycol in tissue as a result of the recapture and rapid presynaptic metabolism of norepinephrine release from the disrupted granule (Cubeddu and Weiner, 1975) . 
Ultimately, it was determined that using the ratio of the metabolite, 3,4-dihydroxyphenylglycol to norepinephrine (DHPG/NE) did indirectly quantify norepinephrine release (Graefe et al., 1972; Cubeddu et al., 1974; Langer and Enero, 1974).

To quantify endogenous DHPG/NE, samples of seminal vesicle smooth muscle were prepared by making $1.5 \%$ homogenates using a McIlwain tissue chopper (0.25 micron ${ }^{2}$ ), Brinkman Polytron (120 seconds at setting 4.5) and a homogenate buffer containing $0.6 \% \mathrm{HClO}_{4}$ (Fisher), $0.1 \%$ sodium metabisulfite (Fisher), and $1.4 \mu \mathrm{M} 3,4-$ dihydroxylbenzylamine (Sigma) as an internal standard. After centrifugation at $30,000 \times \mathrm{g}$ for 10 minutes, the supernatant was syringe filtered through $0.45 \mu \mathrm{m}$ Teflon filters (Titan). The filtrate was stored in microcentrifuge tubes and frozen at $-80^{\circ} \mathrm{C}$ until HPLC analysis. Samples, homogenates and filtrates were kept on ice and protected from light.

To quantify $\mathrm{NE}$ release in vitro, $\mathrm{NE}$ was measured in samples of media from seminal vesicle smooth muscle tissue minces. Smooth muscle was minced with a McIlwain Tissue Chopper $\left(0.25\right.$ micron $\left.^{2}\right)$. Minces were placed in 6 well tissue culture plates in 2 mls Krebs-Henseleit buffer containing $1.13 \mathrm{M} \mathrm{NaCl}$ (Fisher), $47 \mathrm{mM} \mathrm{KCl}$ (Fisher), $25 \mathrm{mM} \mathrm{CaCl}_{2}$ 
(Sigma), $12 \mathrm{mM} \mathrm{MgSO}_{4}$ (Fisher), $56 \mathrm{mM}$ dextrose (Sigma), 11.8

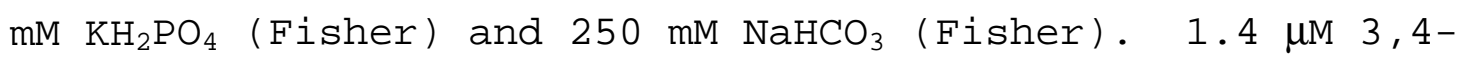
dihydroxybenzylamine was also added to the buffer to serve as an internal standard. $100 \mu \mathrm{M}$ ascorbic acid (Fisher), 1 $\mu \mathrm{M}$ desipramine (RBI) and $1 \mu \mathrm{M}$ yohimbine (RBI) were added to the Krebs-Henseleit buffer to prevent oxidation, reuptake and feedback inhibition of released norepinephrine. Minces were kept in an atmosphere of 95\% oxygen and 5\% carbon dioxide.

Three 15-minute washes were initially done to remove any norepinephrine released from the trauma of harvesting and mincing. Following this, 2-12 minute baseline media samples were collected. All samples were kept on ice, protected from light then frozen at $-80^{\circ} \mathrm{C}$ until HPLC analysis. On the day of analysis, samples were thawed, kept on ice and protected from light. Samples were probe sonicated, syringe-filtered through $0.45 \mu \mathrm{m}$ Teflon filters (Titan), then analyzed by HPLC.

A mobile phase of $0.1 \mathrm{M} \mathrm{NaH}_{2} \mathrm{PO}_{4}$ (Sigma), $0.325 \mathrm{mM}$ octane sulfonic acid (Acros), $0.1 \mathrm{mM}$ EDTA (Eastman Kodak), and $0.25 \mathrm{mM}$ triethylamine (Fisher), brought to pH 3.35 with $\mathrm{H}_{3} \mathrm{PO}_{4}$ (Fisher) was pumped by a Waters 6000 pump at a flow rate of $1.0 \mathrm{ml} / \mathrm{min}$. Samples or standards in 50-100 ul 
volumes were injected with a Waters U6K injector through a Bioanalytical Systems (BAS) Phase II, $100 \mathrm{~mm} \times 3.2 \mathrm{~mm}, 3 \mu \mathrm{m}$ particle size, $\mathrm{C}_{18}$ column. Electrochemical detection using a BAS LC-4C detector was done under the following parameters: $+0.700 \mathrm{~V}, 10-50 \mathrm{nAmp}$ range, and $0.10 \mathrm{~Hz}$ filter. Results were charted on a Hewlett Packard 3395 Integrator under the following parameters: threshold 5, attenuation 8, chart speed 1 , area reject 800,000 .

Standard curves were established using 10, 80 and 160 pmols/50 ul of norepinephrine (RBI) and 3,4dihydroxyphenylglycol (Sigma) and 70 pmol/50 ul of 3,4dihydroxybenzylamine as an internal standard.

E. DNA Quantification for Seminal Vesicle Smooth Muscle Treated In Vivo

DNA quantification followed the methods established by Brunk et al. (1979). Samples of smooth muscle were chopped on a McIlwain tissue chopper (0.25 micron $\left.{ }^{2}\right)$, then homogenized to a 5\% homogenate using a Brinkman Polytron (30 seconds, setting 3). The homogenate buffer consisted of $5 \mathrm{mM}$ MOPS ( $\mathrm{pH}$ 7.4), $1 \mathrm{mM}$ dithiothreital (DTT), $2 \mathrm{mM}$ EDTA, and $1 \mathrm{mM}$ EGTA. After homogenization samples were 
sonicated for 1 minute using a Horn sonicator under the following conditions: power 70, duty cycle 50, continuous. All tubes are kept on ice.

The assay was done using a Shimadzu spectrofluorophotometer at excitation $350 \mathrm{~nm}$, emission 450 nm, band widths $5 \mathrm{~nm}$, and low sensitivity. Fisher Ultra-UV microcuvettes were filled with $1.4 \mathrm{ml}$ of buffer $(100 \mathrm{mM}$ $\mathrm{NaCl}, 10 \mathrm{mM}$ EDTA, $10 \mathrm{mM}$ Tris 7.0) and $0.1 \mathrm{ml}$ of 4',6diamidino-2-phenylindole (DAPI) working dye (made from 0.06 $\mathrm{ml}$ of $1 \mathrm{mg} / \mathrm{ml}$ DAPI stock solution in $5 \mathrm{ml}$ buffer). Blank readings were taken. Readings following sequential $10 \mu l$ additions of sample homogenates were then taken to establish the linear stoichometric range for each sample. Samples ranged in concentration from $0.1-0.3 \mu \mathrm{g}$ of $\mathrm{DNA} / \mu \mathrm{l}$. Standard curves were established using known amounts of DNA $(2,4,6,8$, and $10 \mu g)$. DNA (Calf thymus-Sigma) was prepared as a stock solution of $1 \mathrm{mg} / \mathrm{ml}$ in $0.01 \mathrm{~N} \mathrm{NaOH}$, and were diluted to $0.2 \mathrm{mg} / \mathrm{ml}$ using buffer $(100 \mathrm{mM} \mathrm{NaCl}, 10 \mathrm{mM}$ EDTA, $10 \mathrm{mM}$ Tris 7.0) for the assay. 
F. Detection of Apoptosis by Gel Electrophoresis

In apoptosis, DNA fragments consisting of 180-200 base pairs can be seen in a "laddering" pattern via agarose gel electrophoresis (Wyllie, 1980). This internucleosomal DNA degradation by endonuclease is characteristically associated with apoptosis and not with necrosis (Wyllie, 1980). Therefore, to detect the presence of apoptosis, agarose gel electrophoresis was used.

Seminal vesicles were harvested and the epithelia removed. Tissues were flash frozen in liquid nitrogen then transferred to $-80 \mathrm{C}$ until homogenization at a later date. For homogenization, tissues were thawed by placing in ice cold buffer containing $100 \mathrm{mM} \mathrm{NaCl,} 10 \mathrm{mM}$ EDTA, and $10 \mathrm{mM}$ Tris 7.0. A 2\% homogenate was made by first chopping tissues with a McIlwain tissue chopper then homogenizing with a polytron.

DNA was extracted and prepared for agarose gel electrophoresis in conjunction with Dr. Laura Gibson, in the Department of Microbiology and Immunology at West Virginia University. Cells were lysed and protein digested with proteinase $\mathrm{K}$ for 1 hour at $37^{\circ} \mathrm{C}$. Equal volumes of chloroform and phenol were added. The homogenate mixture was shaken for 30 seconds then spun at 14,000 x 9 for 5 
minutes. The aqueous phase was removed to a new tube and $1 / 10$ volume of $3 \mathrm{M} \mathrm{NaOAC}$ and 1.5 volume of $100 \%$ ice cold ethanol was added. Precipitation occurred overnight at $20^{\circ} \mathrm{C}$. The next day, DNA was pelletted by spinning at 14,000 $\mathrm{x} g$ for 15 minutes. The pellet was dried, resuspended in Tris-EDTA, treated with $5 \mathrm{mg} / \mathrm{ml}$ RNAse for 1 hour at $37^{\circ} \mathrm{C}$, extracted with an equal volume of chloroform, then respun. The aqueous phase was removed and again precipitated using ice cold $100 \%$ ethanol.

$100 \mathrm{ng}$ of sample DNA and $5 \mu \mathrm{l}$ dye were loaded into the wells of a $2 \%$ agarose gel containing $2 \%$ ethidium bromide and covered with $0.04 \mathrm{M}$ tris-acetate, 0.001 M EDTA buffer. The first lane contained a positive control $\mathrm{Kb}$ ladder (Gibco BRL) while the last lane contained a negative sample. The power supply was applied for 2 hours at $90 \mathrm{mV}$. The gel was then exposed to UV light and photographed with a Strategene Eagle Eye II camera. 
G. Seminal Vesicle Smooth Muscle Cell Cultures

Male Hartley guinea pigs were sacrificed and submerged in $70 \%$ ethanol before the seminal vesicle was harvested and the epithelia removed. The clean smooth muscle tissue was then minced in a petri dish containing $1 \mathrm{mg} / \mathrm{ml}$ filter sterilized collagenase (Sigma) in Dulbecco's Modification of Eagle's Medium (DMEM) (Cellgro) or Hanks Balanced Salt Solution (Sigma) with no bovine serum, and incubated for one hour at $37^{\circ} \mathrm{C}$. The sample was then triturated with decreasing pipet size to $5 \mathrm{ml}$ then transferred to a $50 \mathrm{ml}$. tube to settle at unit gravity. The pellet was reconstituted in DMEM containing $292 \mu \mathrm{g} / \mathrm{ml} \mathrm{L}-\mathrm{glutamine}$ (Sigma), $50 \mu g$ penicillin/ml (Sigma), $50 \mu g$ streptomycin/ml (Sigma), $150 \mu g$ neomycin/ml (Sigma) and 10\% heat inactivated fetal calf serum (Biowhittaker). The supernatant was harvested and spun on a Sorvall RT 6000B centrifuge (speed 3). The resultant pellet was also reconstituted in culture medium. Two separate cultures were made with the two reconstituted pellets. Cells were then grown in flasks (Costar) in an incubator at $37^{\circ} \mathrm{C}$, and $5 \% \mathrm{CO}_{2} \cdot$ Previous studies established that cultures appeared to be pure smooth muscle cells based on double staining for nuclei 
(DAPI) and immunocytochemical staining for smooth muscle isoactin (Gerbrosky et al., 1997).

Cells were passed every 2 weeks and grown in media containing 5\% fetal bovine serum (Gibco). Cells were harvested by first removing media and any detached cells, rinsing with HBSS, and trypsinizing (Sigma) for 2 minutes followed by mechanical removal with a rubber policeman to remove attached cells. Media containing $10 \%$ fetal bovine serum was used to stop trypsinization.

For in vitro proliferation studies, six-well culture plates (Costar) were used. Each well was plated with $6-7 \mathrm{x}$ $10^{4}$ cells/well as determined by hemocytometer, and incubated for 24 hours to allow attachment. Treatment groups were then exposed to various agents such as: $1 \mu \mathrm{M}$ phenylephrine (Sigma) in $0.1 \%$ ethanol, $10 \mu \mathrm{M}$ phenylephrine in $0.1 \%$ ethanol, $1 \mu \mathrm{M}$ prazosin (Sigma) in $0.1 \%$ ethanol, $1 \mu \mathrm{M}$ isoproterenol (RBI) in water, and $100 \mu \mathrm{M}$ ascorbic acid (Fisher).

Note: Although phenylephrine is freely soluble in water as well as ethanol, experiments using water vehicle did not show any effect of phenylephrine on cells. 
Control cells were exposed to $0.1 \%$ ethanol or water and $100 \mu \mathrm{M}$ ascorbic acid. Media and agents were replaced daily. Cells were counted using a hemocytometer.

H. Organ Bath Electrical Field Stimulation

Seminal vesicles from male Hartley guinea pigs treated in vivo were harvested. Adventitia was removed, the lumen opened lengthwise and the epithelia removed. Proximal segments of longitudinal smooth muscle were mounted between two platinum electrodes for electrical field stimulation (Grass S44) and attached to a force displacement transducer (Grass 79D) for isometric contraction recording. The proximal $1.5 \mathrm{~cm}$ for adult and $1.0 \mathrm{~cm}$ for prepubertal guinea pigs were used in the organ bath due to the inability of the bath to contain an entire longitudinal adult seminal vesicle smooth muscle. Proximal ends were used since longitudinal smooth muscle was more prevalent proximally than elsewhere (Al-Zuhair et al., 1975). Preparations were placed in an organ bath containing Krebs-Henseleit buffer, kept at room temperature and continuously bubbled with 5\% $\mathrm{CO}_{2}$ and 95\% $\mathrm{O}_{2}$. Tissues were given 1 hour to equilibrate at an initial tension of 2 grams. 
After equilibration, tissues were electrically field stimulated for 30 seconds at $40 \mathrm{~V}$ with train pulses of 0.5 msec. duration, 0.01 msec. delay at varying $\mathrm{Hz}(2,5,10$, 20, 30 and $40 \mathrm{~Hz}$ ). Contractile response was shown to be graded between 2 and $20 \mathrm{~Hz}$, and $30 \mathrm{~Hz}$ was previously shown to stimulate supramaximal contraction without causing significant exhaustion (LaPierre et al., 1993). Organ bath contents were drained and replaced 5 minutes after stimulation was initiated. Tissues were not stimulated again until 15 minutes had passed. After all the seminal vesicle segments were stimulated at $2,5,10,20,30$, and $40 \mathrm{~Hz}$, segments $1 \mu \mathrm{M}$ rauwolscine (RBI) was added to the Krebs-Henseleit buffer and segments were allowed to equilibrate for 1 hour. Tissues were then restimulated at the various $\mathrm{Hz} . \quad 1 \mu \mathrm{M}$ prazosin was then added to the buffer and tissues equilibrated again for 30 minutes before receiving a final $40 \mathrm{~Hz}$ stimulation. $1 \mu \mathrm{M}$ prazosin was found in preliminary dose response studies to maximally inhibit the adrenergically-mediated, electrically-fieldstimulated contraction.

For the study of post-junctional $\alpha_{2}$-adrenoceptors, tissues were prepared as above. However, rather than electrical stimulation, $10 \mu \mathrm{M}$ BHT-933 [6-Ethyl-5, 6, 7,8- 
tetrahydro-4H-oxazolo $[4,5-\mathrm{d}]$ azepine-2-amine

dihydrochloride], a selective $\alpha_{2}$-adrenoceptor agonist (RBI), or $10 \mu \mathrm{M}$ methoxamine $\pm 0.1 \mu \mathrm{M}$ prazosin were used to elicit contraction.

I. $\alpha_{2}$-Adrenoceptor Characterization and Quantification

Ligand binding studies using $\left[{ }^{3} \mathrm{H}\right] \mathrm{RX} 821002$ [2-methoxy$1,4-\left[6,7-{ }^{3} \mathrm{H}\right]$ benzodioxan-2-yl-2-imidazolin $\left.\mathrm{HCl}\right]$ (Amersham) were done to identify, characterize and quantify the $\alpha_{2}-$ adrenoceptor in prepubertal and adult 7-daydihydrotestosterone-treated, normal and castrate guinea pigs. The ligand RX821002 is an $\alpha_{2}$-adrenoceptor antagonist which exhibits relatively high affinity for all the $\alpha_{2}-$ adrenoceptor subtypes (O'Rourke et al., 1994). RX821002 is the 2-methoxy analog of idazoxan. In rabbit and human frontal cortex, idazoxan binds with comparable affinity to $\alpha_{2}$-adrenoceptors and phentolamine-displacable nonstereoselective sites (Convents et al., 1989). In these same tissues, the 2-methoxy analog of idazoxan, $\left[{ }^{3} \mathrm{H}\right] \mathrm{RX} 821002$, was shown to have a 10-fold higher affinity for the $\alpha_{2}$-adrenoceptor $\left(K_{d}=2.8 \mathrm{nM}\right)$ than $\left[{ }^{3} \mathrm{H}\right]$ idazoxan $\left(\mathrm{K}_{\mathrm{d}}=\right.$ 
$24 \mathrm{nM}$ ) and equal affinity with $\left[{ }^{3} \mathrm{H}\right]$ rauwolscine (Vauquelin et al., 1990).

Seminal vesicles were freshly harvested, and the adventitia and epithelia were removed. Seminal vesicle smooth muscles were then chopped on a McIlwain tissue chopper to 0.5 micron $^{2}$ followed by teflon glass homogenization on ice in a 0.32 M sucrose solution containing $5 \mathrm{mM}$ Tris buffer at pH 7.4. A Brinkman polytron was then used to further homgenize the sample.

Homogenates were centrifuged at 1000 x $g$ for 10

minutes. The supernatants were saved and the pellets were rehomogenized and re-spun as previously described. The supernatants were then pooled, centrifuged at 48,000 x $\mathrm{g}$ for 20 minutes, and the resultant supernatant was discarded. The synaptic membrane pellet was then reconstituted in $25 \mathrm{mM}$ sodium phosphate buffer by using the Brinkman polytron (Deupree et al., 1996).

Bradford protein determinations were done on this reconstitution.

Kinetic studies were done to establish protein dependence and equilibration with time of incubation using $0.4 \mathrm{nM}\left[{ }^{3} \mathrm{H}\right] \mathrm{RX} 821002$, the lowest ligand concentration employed in saturation analysis. The analyses for protein dependence and equilibration time were quantified for total 
rather that saturable binding to ensure valid [ $\left.{ }^{3} \mathrm{H}\right] \mathrm{RX} 821002$ binding conditions for all potential components of binding.

For $\alpha_{2}$-adrenoceptor saturation binding experiments, 0.40 to $9.0 \mathrm{nM}$ of $\left[{ }^{3} \mathrm{H}\right] \mathrm{RX821002}$ were added to membrane suspensions and sodium phosphate buffer was added for a final total volume of $200 \mu l$. Reactions were allowed to equilibrate for 20 minutes at room temperature. Saturable binding was determined with a parallel set of reactions that also contained $10 \mu \mathrm{M}$ rauwolscine. Rauwolscine was initially employed because the non-tritiated RX821002 was commercially unavailable at the time. $10 \mu \mathrm{M}$ of rauwolscine represented the minimum concentration of rauwolscine necessary to produce greater than 90\% inhibition of $5 \mathrm{nM}$ $\left[{ }^{3} \mathrm{H}\right] \mathrm{RX821002}$ binding. Subsequently, non-radioactive RX821002 became commercially available. When tested, RX821002 at $1 \times 10^{-7} \mathrm{M}$ generated the same degree of maximum inhibition as $10 \mu \mathrm{M}$ rauwolscine at $5 \mathrm{nM}\left[{ }^{3} \mathrm{H}\right] \mathrm{RX} 821002$ binding

To assess ligand binding specificity, competition experiments were done using 5nM [ $\left.{ }^{3} \mathrm{H}\right] \mathrm{RX} 821002$ and varying concentrations of prazosin (Sigma), phentolamine(Sigma), clonidine, 5HT, rauwolsince (RBI), and 2-methoxyidazoxan (Sigma). Assays were given 20 minute equilibration time. 
Membrane suspensions were then filtered through sodium phosphate presoaked Whatman GF/B glass fiber filter papers with a 10-well minifold (Fisher). Filters were rinsed with sodium phosphate buffer and the trapped radioactivity was counted by liquid scintillation (ScintiSafe by Fisher) photometry.

Scatchard-Rosenthal plots were used to determine $\mathrm{K}_{\mathrm{d}}$ and $B_{\max }$ values. $\quad \mathrm{IC}_{50}$ values were converted to $\mathrm{K}_{i}$ values using the Cheng and Prusoff equation:

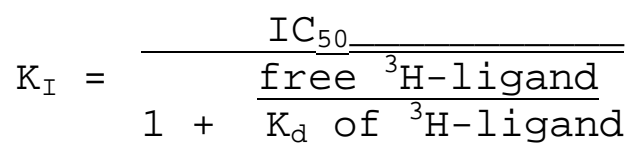

J. PKC Analyses

Tissues were homogenized (Brinkman Polytron setting 3, 30 seconds, three times with 30 second intervals) in $20 \mathrm{mM}$ MOPS (pH 7.4) containing, $2 \mathrm{mM}$ DTT, $1 \mathrm{mM}$ EDTA, 1 mM EGTA, $100 \mu \mathrm{g} / \mathrm{ml}$ leupeptin, $10 \mu \mathrm{g} / \mathrm{ml}$ aprotinin, $10 \mu \mathrm{g} / \mathrm{ml}$ chymostatin A, $10 \mu \mathrm{g} / \mathrm{ml}$ antipain and $1 \mathrm{mM}$ phenylmethanesulfonyl fluoride (PMSF). Homogenates were then centrifuged at $10,000 \times \mathrm{g}$ for 10 minutes to sediment nuclei and unbroken cells. This pellet was then 
resuspended, rehomogenized in the above buffer, and recentrifuged. The supernatants of the original spin and of the subsequent spin were combined and centrifuged at $100,000 \times \mathrm{g}$ for 60 minutes to generate the EGTA soluble fraction.

To assay the protein kinase, the EGTA-soluble fraction was column fractionated on DEAE-cellulose. Assays were performed at $30^{\circ} \mathrm{C}$ using a reaction mixture of $100 \mu \mathrm{l}$ containing $40 \mathrm{mM}$ MOPS (pH 7.2), $5 \mathrm{mM} \mathrm{MgSO}_{4}, 1 \mathrm{mM} \mathrm{DTT}, 20 \mu \mathrm{M}$ $\alpha\left[{ }^{32} \mathrm{P}\right] \operatorname{ATP}(0.5 \mu \mathrm{Ci})$, and $600 \mu \mathrm{g}$ protamine. Cyclic AMPdependent type I and type II kinases were assayed by reaction with and without $10 \mu \mathrm{M}$ cAMP, using $200 \mu \mathrm{g}$ of histone $\mathrm{f}_{2} \mathrm{~b}$ as a substrate. After a 5 minute incubation at $30^{\circ} \mathrm{C}$, duplicate $40 \mu \mathrm{l}$ aliquots were spotted onto $2.3 \mathrm{~cm}$ squares of $\mathrm{P}-81$ phosphocellulose paper and immersed in 1\% sodium pyrophosphate, followed by three 15 minutes washes in the same fluid, a 95\% ethanol rinse and a 3:1 v/v 95\% ethanol:ether rinse. Disks were air-dried then counted in a liquid scintillation spectrophotometer (Durham et al., 1986) .

To further isolate particular PKC isozymes, peak enzymatically active fractions from the DEAE column were pooled and loaded in Minifold I (Schleicher \& Schuell) 
wells. Total proteins from these individual fractions were identical between groups based on Bradford protein analysis of the individual fractions and the pooled sample. The Minifold contained Immobilon P (PVDF) (Millipore) membrane wetted underneath with one sheet of Gel Blot (GBO02) (Schleicher \& Schuell). $500 \mu l$ samples with protein ranging from 1.5 to $25 \mu \mathrm{g}$ were applied. The membrane was prepared following Tropix, Inc. Western-Light Chemiluminescent Detection System Protocol. Primary mouse monoclonal antiPKC antibodies (Transduction Labs) were applied to the membrane in a concentration of $2 \mu \mathrm{g} / \mathrm{ml}$ in a 90 minute incubation. Unbound primary antibody was rinsed off before a 90 minute incubation in secondary Donkey anti-mouse IgG, alkaline phosphate-conjugated antibody in a 1 : 5000 dilution with buffer containing $0.2 \%$ I-Block (Tropix), $0.1 \%$ Tween-20 and $1 / 10^{\text {th }}$ volume PBS. Unbound antibody was again rinsed off and Ultra-Pure CSPD chemiluminescent substrate (Tropix) was applied.

Chemiluminescence was recorded on Kodak X-OMAT film and analyzed and quantified by optimus densitometer. Antibodies were used to detect PKC isozymes $\alpha, \beta, \delta, \varepsilon, \gamma$, $\theta$, and $\xi$. Isozymes $\alpha, \varepsilon, \gamma, \theta$, and $\xi$ were detectable in appreciable quantities. The $\beta$ and $\delta$ isozymes were either 
undetected or detected only in trace amount unquantifiable by densitometry. The $\varepsilon, \theta$, and $\xi$ isozymes demonstrated wide intra-assay variation and were not subsequesntly pursued. Only the $\alpha$ and $\gamma$ isozymes exhibited a stoichiometric relationship between protein concentration and chemiluminescence and thus were the 2 isozymes quantified in this study. In preparation for $\mathrm{PKC} \alpha$ isozyme quantification by dot blots, a protein dependence study was done using seminal vesicle smooth muscle from prepubertal and adult castrates and PKC $\alpha$. Although not stoichiometrically linear, relative density did increase with increased protein applied in a linear fashion. For prepubertal castrates, the amount of protein (x) was related to chemiluminescent density (y) such that $y=0.022 x+0.671$ with correlation $r^{2}=0.80 . \quad$ In adult castrates, $y=0.019 x+0.228, r^{2}=0.97$. This showed that chemiluminescent density would be dependent upon the amount of protein applied. 
K. Statistical Analyses

Statistical analyses, generally one-way analysis of variance, Students t-test or Tukey-Kramer's test were employed in this work. Statistical significance was defined at $\mathrm{p} \leq 0.05$. Graphs were done using JMP Statistical Software, Microsoft Excel 97, or GraphPad.

\section{Results}

A. Specific Aim 1: Androgen in vivo induced increased norepinephrine release in the seminal vesicle smooth muscle of prepubertal castrates.

As shown in previous studies of rat vas deferens (Tarlov and Langer, 1971; Graefe et al., 1972; Cubeddu et al., 1974), the predominant metabolite of norepinephrine (NE) in the guinea pig seminal vesicle smooth muscle was found to be 3,4-dihydroxyphenylglycol (DHPG) (Johnson, 1996). By using $\left[{ }^{3} \mathrm{H}\right]$ norepinephrine, it was found that more than $70 \%$ of the spontaneous outflow of $\mathrm{NE}$ in rat vas 
deferens was deaminated to DHPG, with the next highest metabolite via catachol-o-methyltransferase, accounting for 14\% (Graefe et al., 1972). DHPG was positively identified by comparison of retention times with known DHPG standard on HPLC.

The use of endogenous DHPG/NE ratio has been used as an indicator if in vivo NE release. Prepubertal guinea pigs treated in vivo for 7 days with $10 \mathrm{mg} / \mathrm{kg}$ dihydrotestosterone (DHT) showed a tripling of endogenous DHPG/NE over oil-treated prepubertal controls in seminal vesicle smooth muscle homogenates (fig. 1). 
Figure 1: Effects of DHT on DHPG/NE in seminal vesicle smooth muscle

DHPG/NE

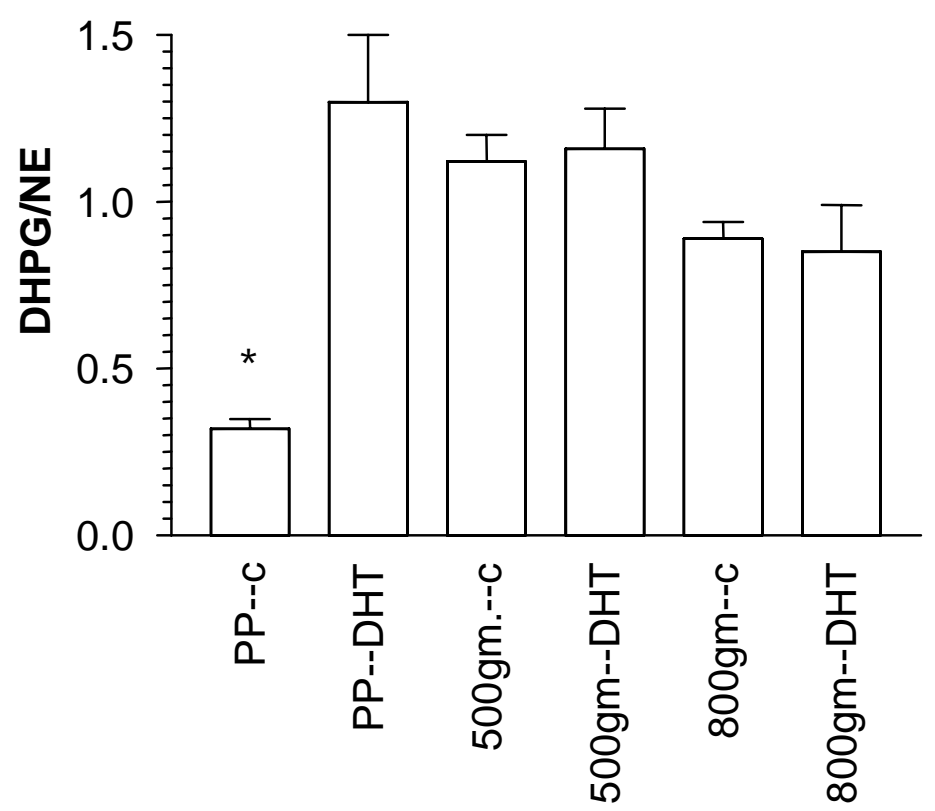

Figure 1: Norepinephrine release in prepubertal (PP) seminal vesicle smooth muscle, as measured by DHPG/NE, increased three-fold with $10 \mathrm{mg} / \mathrm{kg}$ DHT replacement as compared to prepubertal castrate (c) control. DHT-treated prepubertal ratios were similar to adult levels which were resistant to androgen-induced change. In prepubertal animals, castration was done prepubertally at 6-7 days of age. Adults were castrated at approximately 500 grams or at 800 grams. Prepubertal groups had $n=8-15$, weighing approx. 250 gms. Adult groups had $n=4-8$.

${ }^{*} \mathrm{p} \leq 0.05$ compared to all other groups.

Norepinephrine release in adult guinea pigs showed no change with DHT treatment and were similar to levels measured in prepubertal castrates treated with DHT for 7 days. This indicated that once norepinephrine release was 
elevated by androgen, it remained elevated into adulthood when it was no longer dependent upon androgens.

The effect of other sex steroids on norepinephrine release was also examined.

Figure 2: The Effect of Various Sex Steroids on Norepinephrine Release in Seminal Vesicle Smooth Muscle

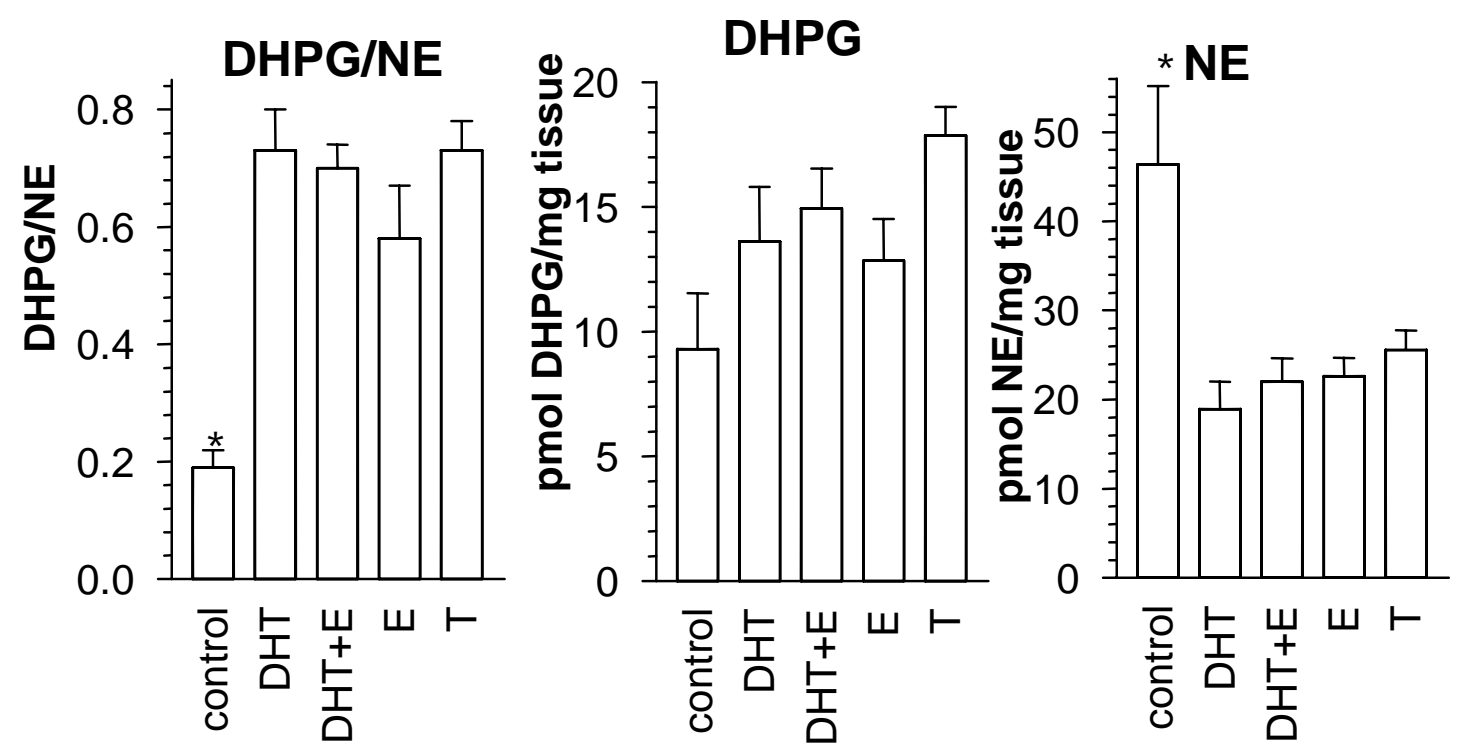

Figure 2: Prepubertal guinea pigs were castrated at 6-7 days of age. $10 \mathrm{mg} / \mathrm{kg}$ of dihydrotestosterone (DHT) and testosterone $(\mathrm{T}), 0.01 \mathrm{mg} / \mathrm{kg}$ estradiol benzoate (E), or oil (control) were given daily for 7 days. $n=6-15$ ${ }^{*} \mathrm{p} \leq 0.05$

Previous evidence demonstrated that the actions of testosterone on certain central nervous system neurons 
depended upon its aromatization by $5 \alpha$-reductase and the combined effects of the resultant dihydrotestosterone and estradiol (Christensen and Clemens, 1975). Estradiol was also known to stimulate increased seminal vesicle smoooth muscle DNA (Mariotti and Mawhinney, 1981). Therefore, estradiol was examined with the hypothesis that it may interact with dihydrotestosterone in norepinephrine release. While norepinephrine release was increased in response to estradiol, there was no significant interaction with dihydrotestosterone (fig. 2). The effects of testosterone were duplicated by dihydrotestosterone alone in prepubertal castrate animals. This was consistent with other parameters examined in seminal vesicle smooth muscle (Neubauer and Mawhinney, 1981). Dihydrotestosterone alone was thus the androgen employed as it would eliminate the question of estradiol involvement in any androgenic effect. 
Figure 3: Effects of DHT on DHPG and NE concentrations in prepubertal and adult seminal vesicle smooth muscle

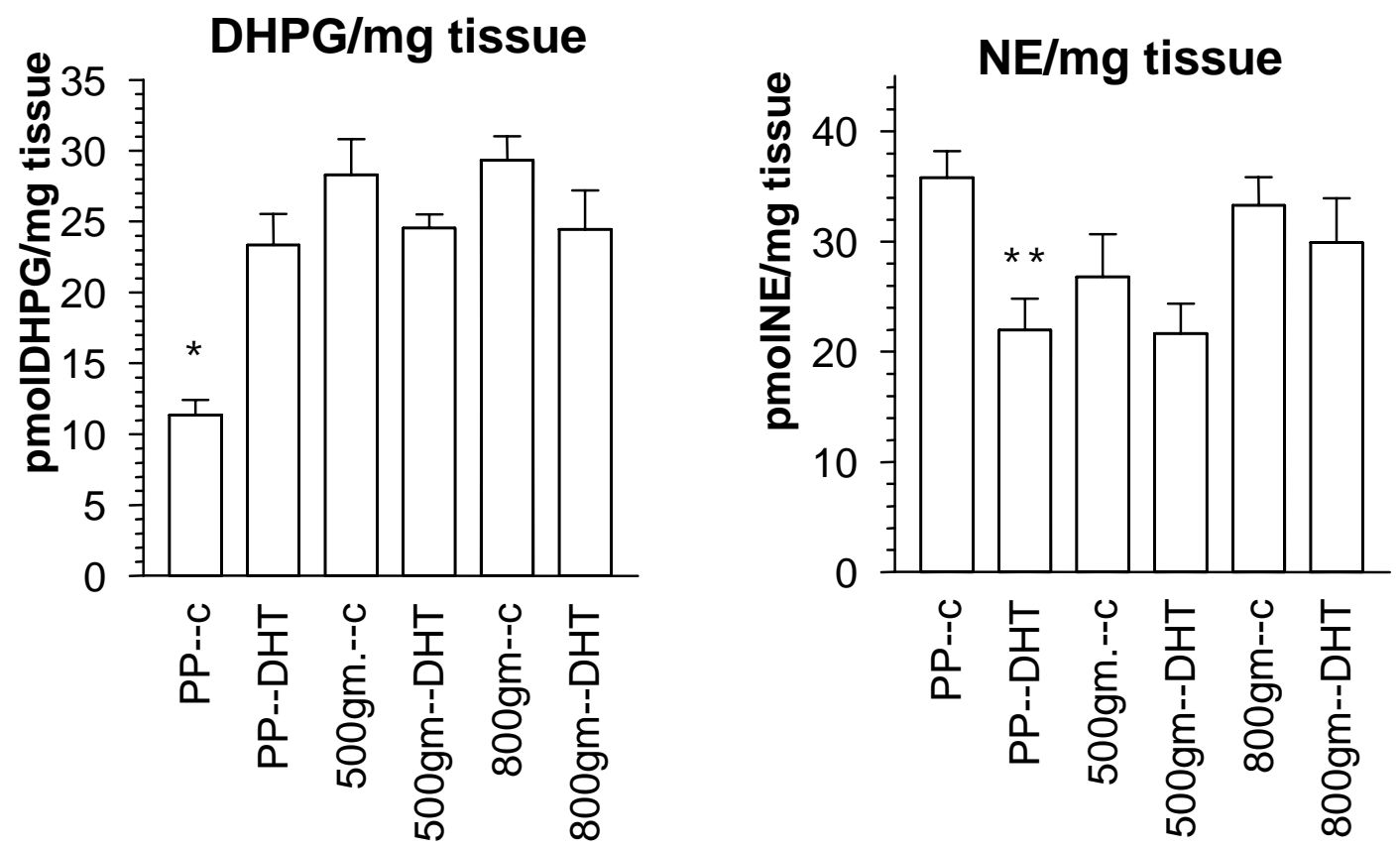

Figure 3: The absolute numbers here were used to calculate the ratios in Fig.1. In prepubertal castrates, norepinephrine (NE) was released and no longer contained within the smooth muscle, resulting in a drop in $\mathrm{NE}$ concentration. However, due to the increased NE release, the concentration of metabolite DHPG increased within the tissue.

$\star \mathrm{p}<0.05$

$\star \star \overline{\mathrm{p}}<0.05$ compared tp PP-C

Evaluating the individual components of the DHPG/NE ratio (fig. 1) revealed that dihydrotestosterone (DHT) had opposite effects on the concentrations of DHPG and norepinephrine (fig. 3). This pattern of change was expected since the release of norepinephrine would cause more deaminated product (DHPG) to be formed while the 
stored amount of parent norepinephrine may be diminished. Once again, DHT-treated prepubertal tissues showed similar concentrations of DHPG and $\mathrm{NE}$ as measured in adult castrate and adult DHT-treated castrate tissues, indicating NE release was sustained at relatively high levels and became androgen-resistant in adults.

Simultaneous experiments were also done to examine the question of whether severing the preganglionic nerve supply to the guinea pig seminal vesicle antagonized the DHTinduced norepinephrine release during the proliferative phase of growth. Decentralization of the hypogastric nerve was performed and confirmed by the lack of seminal vesicle contraction in response to directly applied electrical stimulation of the hypogastric proximal to the severed nerve in situ. 
Figure 4: Hypogastric nerve decentralization did not effect $\mathrm{DHPG} / \mathrm{NE}$, DHPG or $\mathrm{NE}$

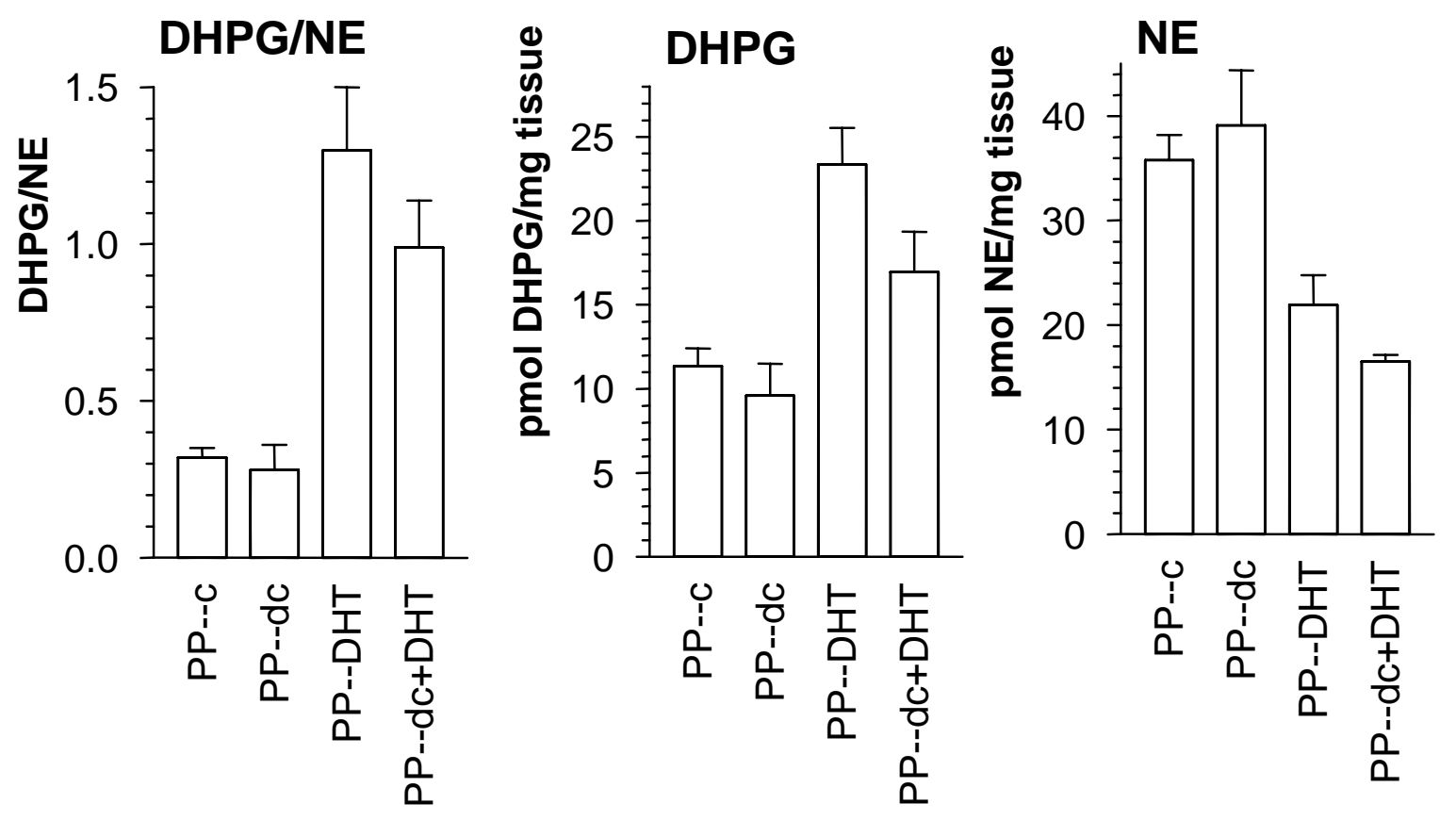

Figure 4: Castration (C) and decentralization (d) were done during the same surgery on days $6-7$ of age. $n=8-15$. There were no significant differences due to decentralization.

Decentralization did not inhibit norepinephrine release as measured by DHPG/NE ratio in prepubertal guinea pigs (fig. 4). This suggested that basal norepinephrine release was also not effected by decentralization and further indicated that androgen-induced neurotransmission was localized to the post-ganglionic fiber.

A time course of the DHPG/NE ratios in prepubertal castrates, completed prior to the research presented here (E. A. Johnson, 1996), showed that significant increases 
begin on the third day of DHT treatment and peaks at day 5 of treatment. The ratio continued to be elevated to the seventh and last day of treatment. The increases in these studies showed the same magnitude as recorded in this present investigation (fig. 5).

Figure 5: Time course of measured NE release in seminal vesicle smooth muscle homogenates from prepubertal castrates treated with DHT

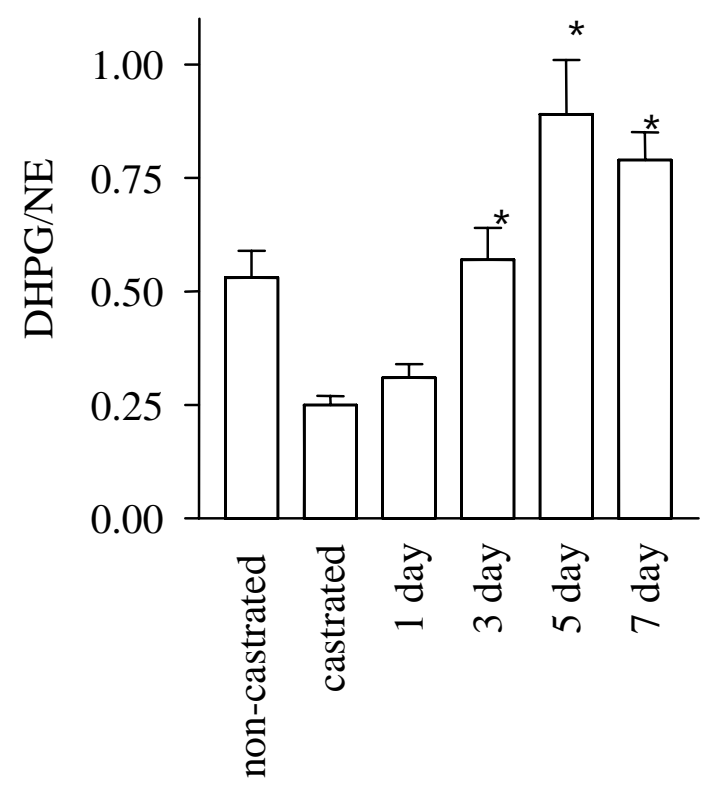

Figure 5: Norepinephrine release (DHPG/NE) increased significantly on day 3, peaking by day 5. (Data by E. A. Johnson, 1996).

${ }^{\star} \mathrm{p} \leq 0.05$ compared to castrate control.

These ex vivo measurements of norepinephrine release from the homogenates were then compared and confirmed with studies in which norepinephrine release was directly 
measured from the incubation media from minces of in vivo androgen-treated, prepubertal castrate seminal vesicle smooth muscle. Direct measurements of norepinephrine from the minces also eliminated any questions regarding systemic norepinephrine. Ascorbic acid, desipramine and yohimbine were added to the buffer to prevent oxidation, reuptake and feedback inhibition of released norepinephrine respectively.

Basal release, rather than electrically or potassium stimulated release, was of interest in an attempt to relate the findings to proliferation and differentiation. Maximal nerve activity from electrical or potassium stimulation was not pursued since it would more closely resemble the nerve activity seen post-pubertally during ejaculation. To ensure release, rather than leakage due to trauma, was being measured, three 15-minute washes were done prior to collection.

A preliminary study using adult normal seminal vesicle smooth muscle was done to show that norepinephrine released into the $2 \mathrm{ml}$ of media was proportionate to the amount of smooth muscle. Using $134 \mathrm{mg}$ and $226 \mathrm{mg}$ of smooth muscle, the $\mathrm{NE}$ released into the media were 39.48 and 78.42 pmoles respectively, indicating 0.29 and 0.35 pmole of $\mathrm{NE}$ released per mg tissue. 
Figure 6: The effect of DHT on baseline norepinephrine release as measured directly in prepubertal castrate minced seminal vesicle smooth muscle

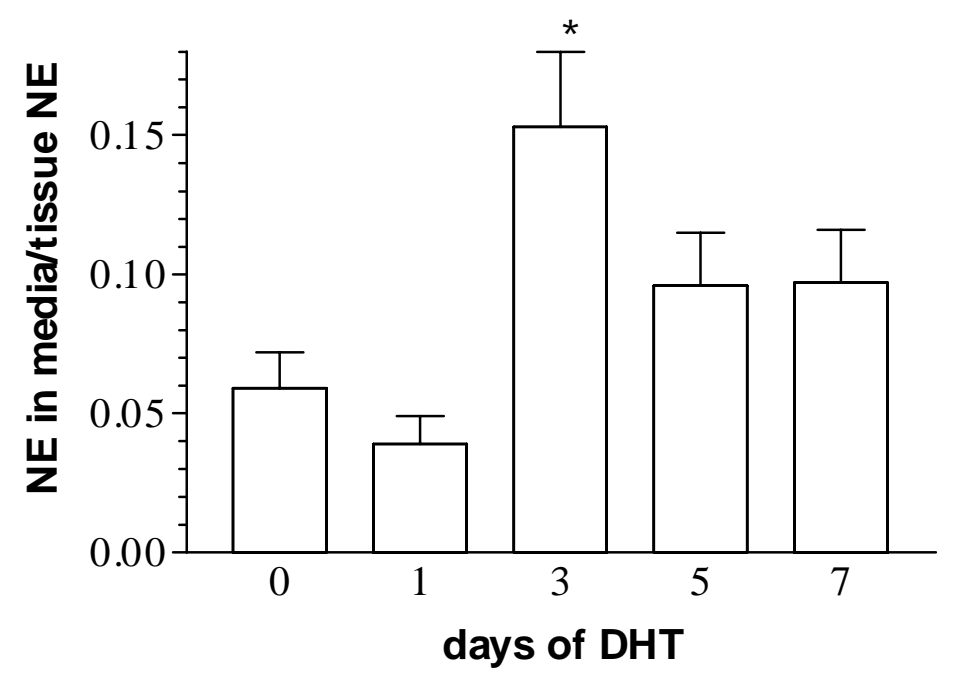

Figure 6: Prepubertal castrate guinea pigs (approx. 250 gms) were treated in vivo then seminal vesicle smooth muscle was harvest and minced. Minces underwent 3-15 minute washes, then the Krebs-Henseleit buffer was collected as the baseline after a 12 minute, post-wash interval. Norepinephrine was quantified by HPLC. Release was expressed as norepinephrine released into the media per norpinepinephrine within the tissue. $n=3$. ${ }^{*} \mathrm{p} \leq 0.05$ compared to all other groups.

Norepinephrine release in the minces increased with DHT-treatment showing a similar time-course as demonstrated above in figure 5. Androgen treatment caused release to increase significantly by day 3. Release remained high on days 5 and 7 although it was not significantly different from control. The percentage of initial norpepinephrine within the tissue which was released into the media during 
the point of collection was as follows: control=5.9\%, 1-day $\mathrm{DHT}=4.0 \%, 3-\mathrm{day}=15.2 \%, 5-\mathrm{day}=11.8 \%$, and $7-\mathrm{day}=11.4$. Figure 5 showed peak release on day 3 and ex vivo data showed increased release on day 5. This may be due to ex vivo and in vitro differences in metabolic activity, pathways and uptake.

B. Specific Aim 2: Norepinephrine mediated androgeninduced proliferation of seminal vesicle smooth muscle in Vivo.

1. Reserpine at the minimum dose to maximally deplete norepinephrine in vivo selectively antagonized seminal vesicle smooth muscle proliferation and PKC down-regulation in androgen-treated animals.

Previous studies have shown that 7 day treatment with $10 \mathrm{mg} / \mathrm{kg}$ dihydrotestosterone in prepubertal guinea pigs caused proliferation of the seminal vesicle smooth muscle as measured by DNA content (Mariotti et al., 1992). The results presented above, indicated that norepinephrine release was increased with androgen treatment in prepubertal guinea pigs concurring with a similar time course of increased DNA synthesis. In adults, NE release 
was androgen-resistant under conditions in which cell number was also androgen-resistant (Mariotti et al., 1992). To address the question of whether NE mediated the androgen-induced proliferation of seminal vesicle smooth muscle, in vivo experiments were done using the drug reserpine which depletes norepinephrine by disrupting storage and uptake into the granule (Bertler et al., 1961). Because norepinephrine is co-transmitted with adenosine triphosphate (ATP) (Burnstock et al., 1972), there was some concern that ATP may be effected by reserpine. However, studies showed that reserpine at maximum norepinephrinedepleting dosages did not affect ATP (Kirkpatrick and Burnstock, 1987).

Preliminary studies showed that a single dose of reserpine at $0.30 \mathrm{mg} / \mathrm{kg}$ depleted seminal vesicle smooth muscle norepinephrine to levels undetectable by HPLC for 48 hours in $100 \%$ of animals. By 72 hours, norepinephrine levels began to rise. However, the crucial study was to determine the regimen of reserpine treatment in androgentreated and control animals to deplete norepinephrine during an entire 5-day course of treatment.

Reserpine dose-response studies were done in androgentreated and control groups to determine the minimum dose of reserpine necessary to maximally deplete norepinephrine to 
undetectable levels as quantified by HPLC in seminal vesicle smooth muscles of $100 \%$ of the animals. Time studies were also done to determine the appropriate reserpine dose necessary to deplete norepinephrine during the entire treatment regimen.

Table 1: 24 hour Reserpine Dose Response in Prepubertal Oil-treated Castrate Controls

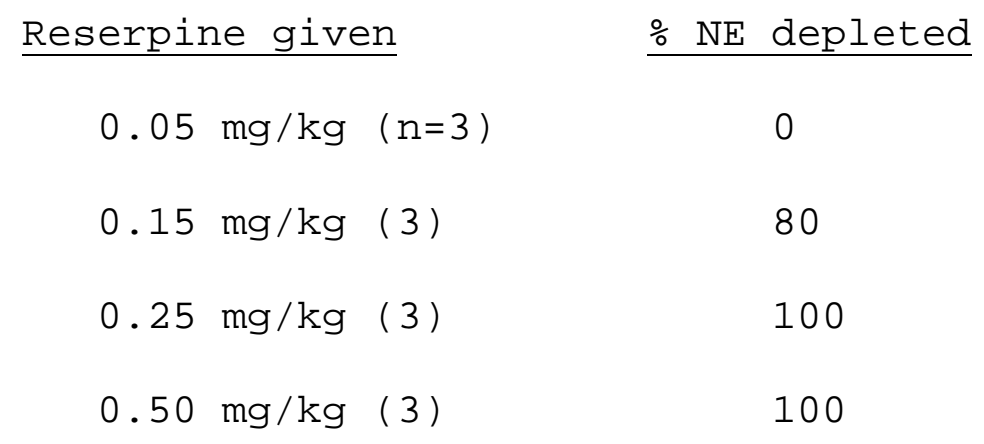

Table 1: HPLC analysis indicated that $0.25 \mathrm{mg} / \mathrm{kg}$ reserpine i.p. was necessary to deplete $\mathrm{NE}$ to undetectable levels in seminal vesicle smooth muscle in all prepubertal castrate control animals. This $0.25 \mathrm{mg} / \mathrm{kg}$ dose was also used to pre-treat DHT-treated animals 24 hours prior to the first DHT administration.

Time course studies were done during which HPLC analysis was done after 48 hours, 72 hours, 4 days and 5 days of daily reserpine treatment. These studies showed that $0.25 \mathrm{mg} / \mathrm{kg}$ reserpine, i.p., given daily, depleted norepinephrine to levels undetectable by HPLC in seminal vesicle smooth muscle in $100 \%$ of oil-treated castrate 
control animals for the entire 5 day oil-treatment regimen (not shown). This regimen had no significant effect on castrate seminal vesicle smooth muscle DNA (SVSM-DNA) (fig. 7) .

Figure 7: The Effect of 5-day, $0.25 \mathrm{mg} / \mathrm{kg}$ Reserpine Treatment on Seminal Vesicle Smooth Muscle (SVSM)-DNA in prepubertal castrates

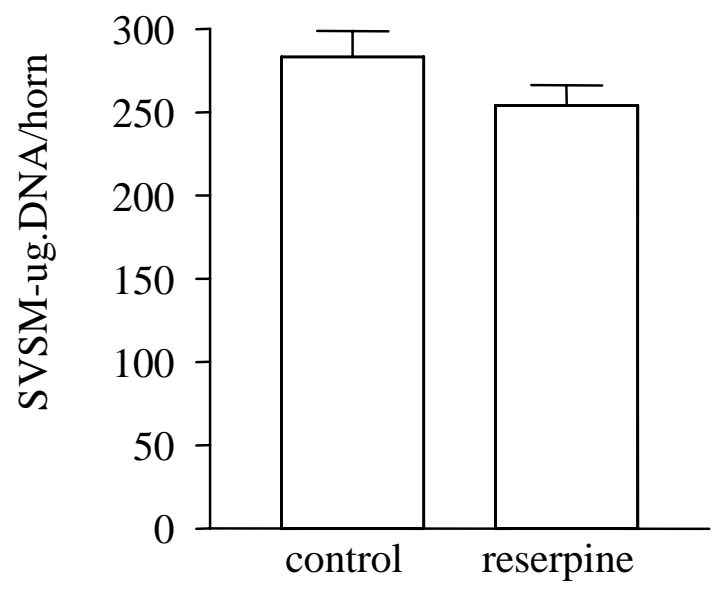

Figure 7: $0.25 \mathrm{mg} / \mathrm{kg}$ reserpine, i.p. daily for 5 days did not significantly reduce DNA $(\mu \mathrm{g})$ content in seminal vesicle smooth muscle in prepubertal castrates.

Animals treated with $10 \mathrm{mg} / \mathrm{kg}$ dihydrotestosterone (DHT) were found to require a higher dose of reserpine to deplete norepinephrine for the entire 5 days of DHT treatment regimen. When initially given the same $0.25 \mathrm{mg} / \mathrm{kg} /$ day dose, it was noticed that DHT-treated animals experienced almost no mortality as well as morbidity such 
as lethargy, diarrhea and weight loss, compared to reserpine-only groups. Dose response studies were repeated for guinea pigs treated with androgen for 1,3 and 5 days. It was determined that after a pretreatment $0.25 \mathrm{mg} / \mathrm{kg}$ reserpine dose, $0.75 \mathrm{mg} / \mathrm{kg}$ of reserpine given daily intraperitoneally was necessary to deplete norepinephrine in 5 day, DHT-treated guinea pigs. Hence, oil-treated controls were also pretreated with $0.25 \mathrm{mg} / \mathrm{kg}$ reserpine. The reason for the discrepancy in reserpine doses in DHT versus oil-treated controls was not explored. The important issue was to determine the minimum dose of reserpine necessary to deplete seminal vesicle smooth muscle norepinephrine to levels undetectable by HPLC in $100 \%$ of animals within the treatment groups. 
Figure 8: Effect of Norepinephrine-Depletion on AndrogenInduced Seminal Vesicle Proliferation

tissue weight

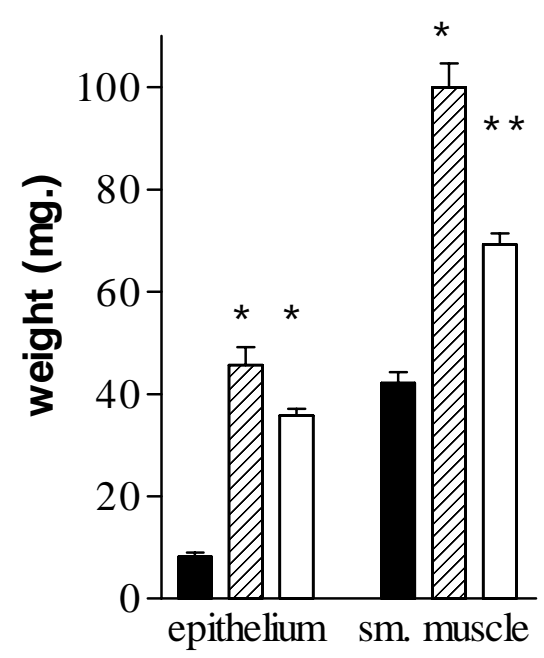

DNA/horn

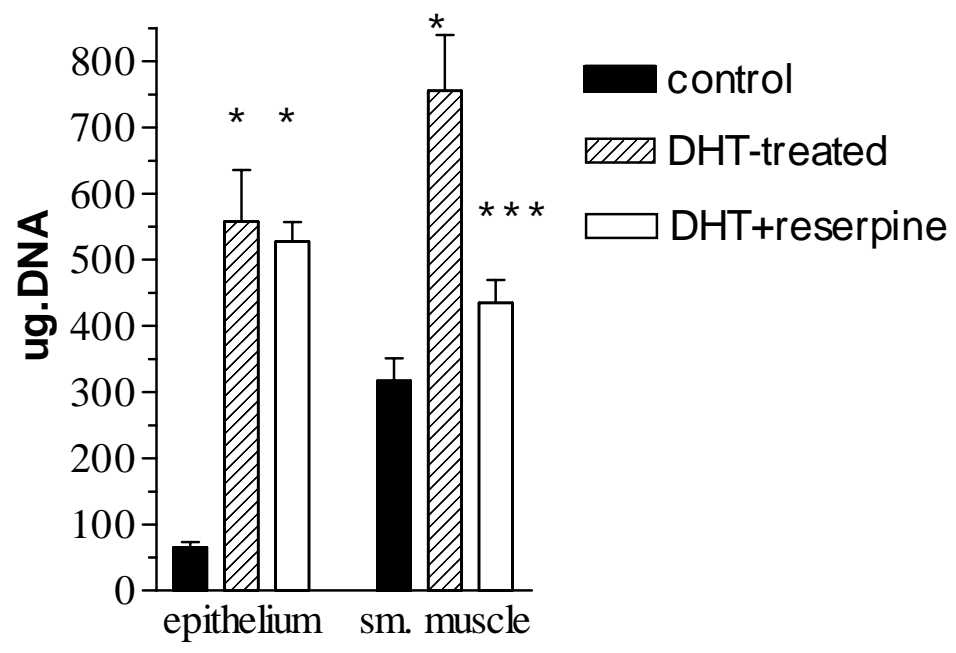

Figure 8: Animals were castrated and decentralized at 6 days of age. After a 10 day post-castration recovery period, animals were pretreated with $0.25 \mathrm{mg} / \mathrm{kg}$ reserpine, i.p., or with vehicle. 24 hours after the pretreatment, 10 $\mathrm{mg} / \mathrm{kg}$ dihydrotestosterone (DHT) or oil treatment, and 0.75 $\mathrm{mg} / \mathrm{kg}$ reserpine or vehicle was given daily for 5 days. Epithelium, which is cholinergically innervated, was not effected by $\mathrm{NE}$ depletion. Control $\mathrm{n}=5$. DHT $\mathrm{n}=7$. DHT+reserpine $\mathrm{n}=14$. ${ }^{\star} \mathrm{p} \leq 0.05$ compared to control. ${ }^{*} \mathrm{p} \leq 0.05$ compared to control and DHT-treated. $\star \star * \mathrm{p} \leq 0.05$ compared to DHT-treated.

The data show that norpinephrine depletion by reserpine had no significant effect on androgen-induced epithelial growth as measured by wet weight and DNA. The unperturbed epithelium also served as a control for any non-specific and anti-androgenic effects of reserpine. 
Because the epithelium is primarily cholinergically innervated, agents acting selectively upon adrenergic innervation would not be expected to affect the epithelium. It has been confirmed in mouse brain that reserpine in vivo did not affect acetylcholine levels (Palfai et al., 1986). Norepinephrine-depletion did affect the adrenergically innervated smooth muscle compartment. Norepinephrinedepletion reduced the androgen-induced increase in wet weight by $31 \%$ and in DNA content by $42 \%$ without causing a change in cell size as measured by RNA/DNA ratio 10.0014 t 0.0003 for DHT versus $0.0018 \pm 0.0003$ for DHT+reserpine). In androgen-treated guinea pigs, reserpine did cause a significantly small decrease in total body weight of the guinea pig when weighed on day of sacrifice. Androgentreated prepubertal castrates weighed $278.20 \pm 5.65 \mathrm{gms}$. on day of sacrifice compared to guinea pigs treated additionally with reserpine which weighed $232.12 \pm 10.93$ gms. This $16.6 \%$ difference in total body weight was not enough to account for the $31 \%$ wet weight decrease in seminal vesicle smooth muscle or the $42 \%$ decrease in DNA seen in reserpine-treated animals (fig. 8).

An experiment using prepubertal guinea pigs having undergone castration alone was done to determine whether the decentralization, as done in the prepubertal castrates 
in the experiment above, had any effect on seminal vesicle smooth muscle response to DHT+reserpine (fig. 9).

Figure 9: Decentralization had no significant effect on castrate, prepubertal guinea pig seminal vesicle smooth muscle

tissue weight

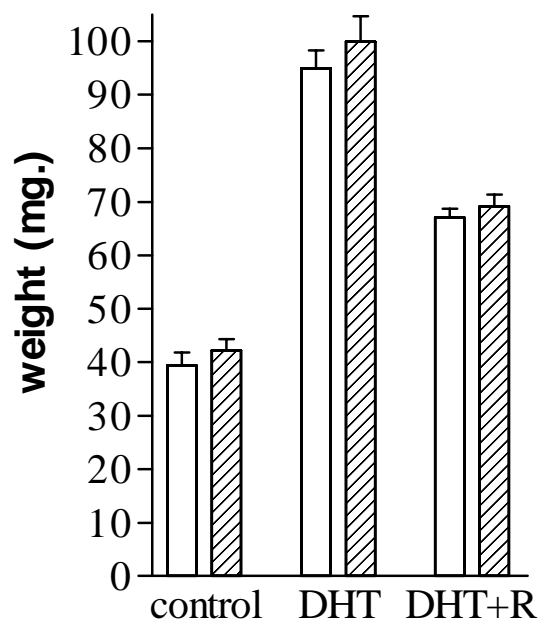

DNA/horn

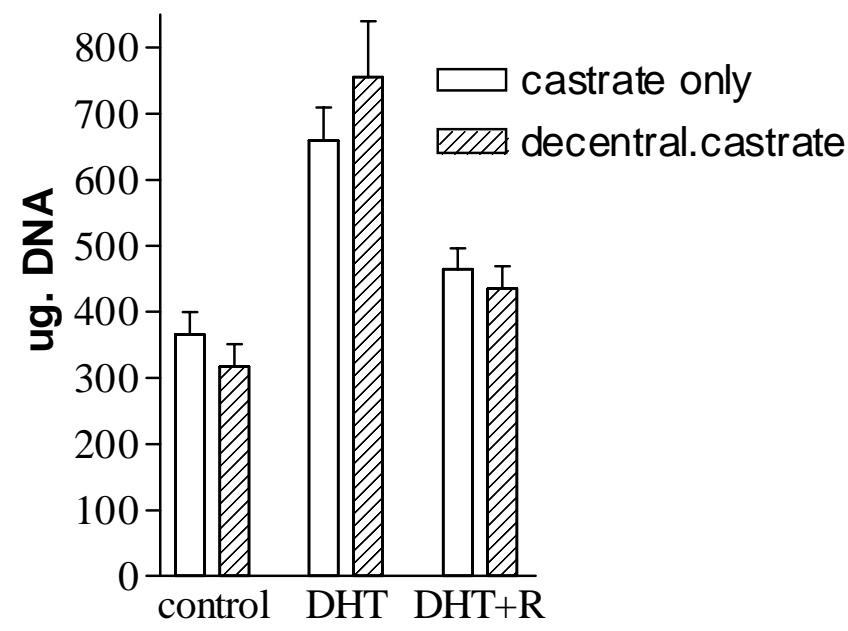

Figure 9: Decentralization had no significant effect on prepubertal castrate, seminal vesicle smooth muscle compared to castration alone. Decentralized data were reproduced from figure 6 . For castrate-only animals, n=14 for controls, 10 for DHT-treated groups, and 19 for DHT+Reserpine.

Because decentralization did not effect norepinephrine release (fig. 1), it was anticipated and recorded that decentralization did not effect the smooth muscle response to androgen and reserpine. 
The down-regulation of protein kinase $C(P K C)$ and changes in cAMP in response to norepinephrine-depletion by reserpine were also examined. It has been shown that a reduction of total $\mathrm{PKC}$ activity occurred in response to androgen-induced proliferation of prepubertal guinea pig seminal vesicle smooth muscle and was androgen-resistant in association with the terminal differentiation seen in adults (Mariotti et al., 1992). Changes in PKC were compared to changes in CAMP-dependent protein kinases which remained androgen-sensitive in both prepubertal and adult animals (fig. 10). 
Figure 10: The time course of androgen's effect on PKC and the interaction of reserpine in prepubertal castrate seminal vesicle smooth muscle

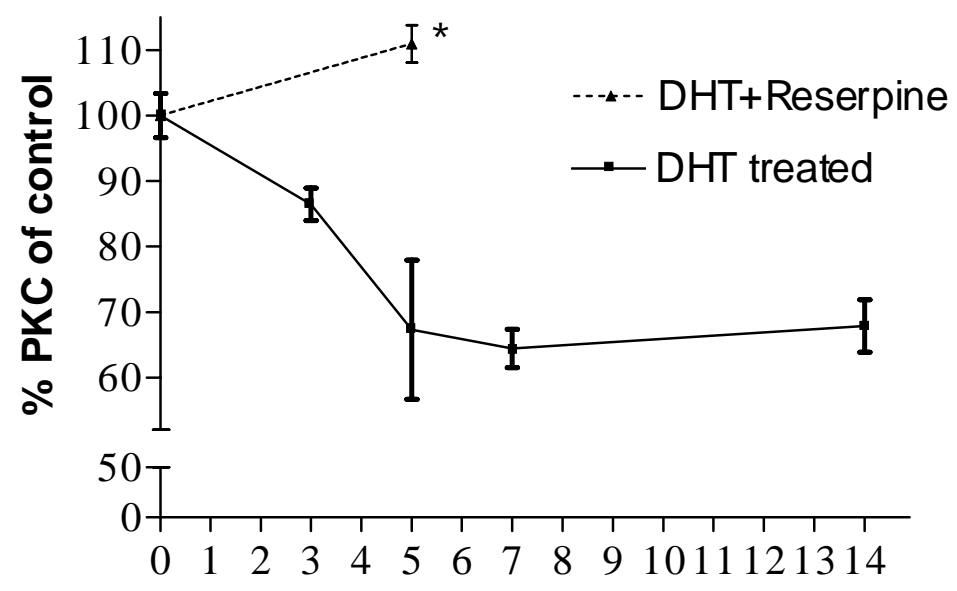

days of DHT treatment

Figure 10: Soluble PKC activity decreased with androgen treatment. Norepinephrine-depletion by reserpine antagonized this effect. Animals treated with reserpine were treated for only 5 days due to the deleterious effects of reserpine. $\mathrm{n}=3$ with each $\mathrm{n}$ representing a pool of at least 6 prepubertal animals weighing approx. 250 gms. Control activity $=473+19 \mathrm{pmol} /\left[{ }^{32} \mathrm{P}\right]$ transferred/fraction/5 mg soluble protein applied to the DEAE column.

${ }^{*} \mathrm{p} \leq 0.05$ compared to DHT-treated.

Experiments done here confirmed the down-regulation of PKC with androgen-treatment. Norepinephrine-depletion by reserpine did prevent the down-regulation of $\mathrm{PKC}$ in androgen-treated animals, such that the level of activity was comparable to control animals that were not exposed to androgen and showed no proliferation. In contrast, cyclicAMP dependent type II kinase was unchanged by norepinephrine-depletion (239.1 \pm 24.1 for DHT only versus 
$267.3 \pm 32.3$ for $\mathrm{DHT}+$ reserpine (units in pmol/ [ $\left.{ }^{32} \mathrm{P}\right]$

transferred/fraction/mg soluble protein applied to the DEAE column))

Figure 11: Relative amounts of $\mathrm{PKC} \alpha$ as measured by chemiluminesce

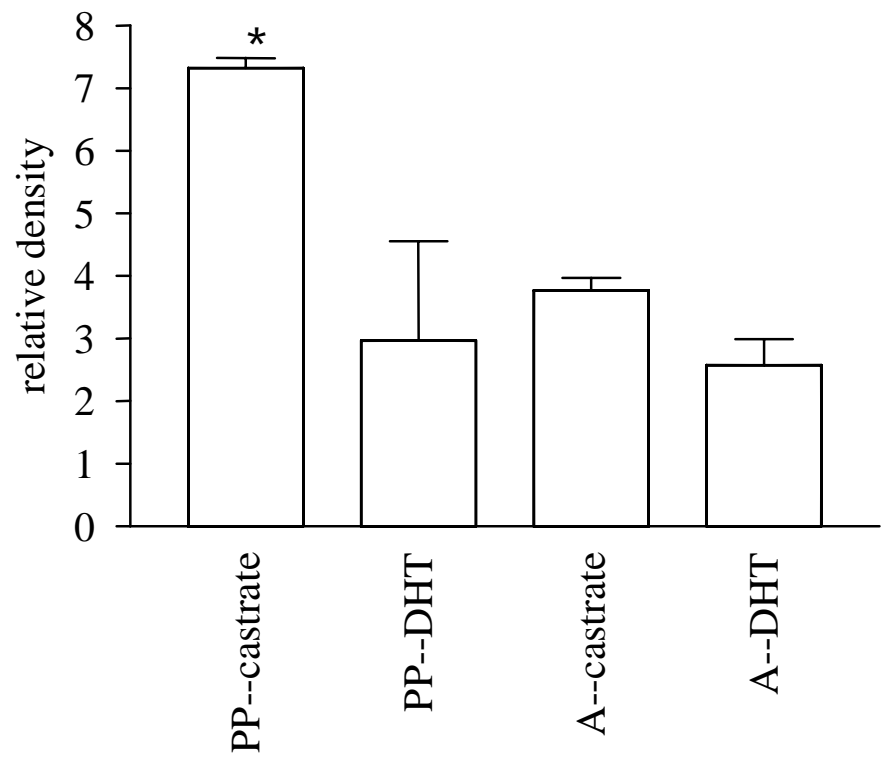

Figure 11: PKC $\alpha$ levels were down-regulated in prepubertal animals with 7-day androgen treatment, yet were unchanged in adults. Chemiluminescence was quantified by densitometer. $\mathrm{n}=3$. $12 \mu \mathrm{g}$ of protein was used per well and film was exposed for lhour. $P K C \gamma$, which did not change with DHT-treatment, was used as a control. PP=prepubertal (approx. $250 \mathrm{gms}$ ). A=Adult (800-900 gms). ${ }^{*} \mathrm{p} \leq 0.05$ compared to all other groups.

A brief examination of the immunoreactive $\operatorname{PKC} \alpha$ and $\gamma$ isozymes revealed that $\mathrm{PKC} \alpha$ activity in prepubertal castrates directly followed the down-regulation of total 
PKC (fig. 10) by 7-day androgen treatment. PKC $\gamma$ was uneffected by androgen treatment. It was previously shown that PKC enzymatic activity in adult castrate seminal vesicle smooth muscle was unresponsive to androgen treatment (Mariotti et al., 1992), as is shown in figure 11. However, in adulthood, total PKC enzymatic activity returned to prepubertal castrate control levels (Mariotti et al., 1992), which was not represented in the immunoreactive PKC $\alpha$ fraction. A preliminary experiment to determine the effect of 5-day reserpine treatment on androgen-induced changes in PKC $\alpha$ was inconclusive which may be due to differences in length of androgen administration. No further study was conducted on PKC isozymes. 


\section{B. Specific Aim 2:}

2. Norepinephrine stimulated proliferation in vitro in seminal vesicle-derived smooth muscle cells via the $\alpha_{1}$-adrenoceptor.

The effect of fetal bovine serum (FBS) concentration on adult guinea pig seminal vesicle smooth muscle cell cultures was studied. Cells were initially plated at $1 \mathrm{x}$ $10^{4}$ cells per flask and cultured for six days with 5\%, $7.5 \%$, $10 \%$, or $20 \%$ FBS. The concentration of FBS did effect cell number with increasing FBS yielding more cells. 
Figure 12: The concentration of fetal bovine serum (FBS) effected cell number in seminal vesicle smooth muscle cultures

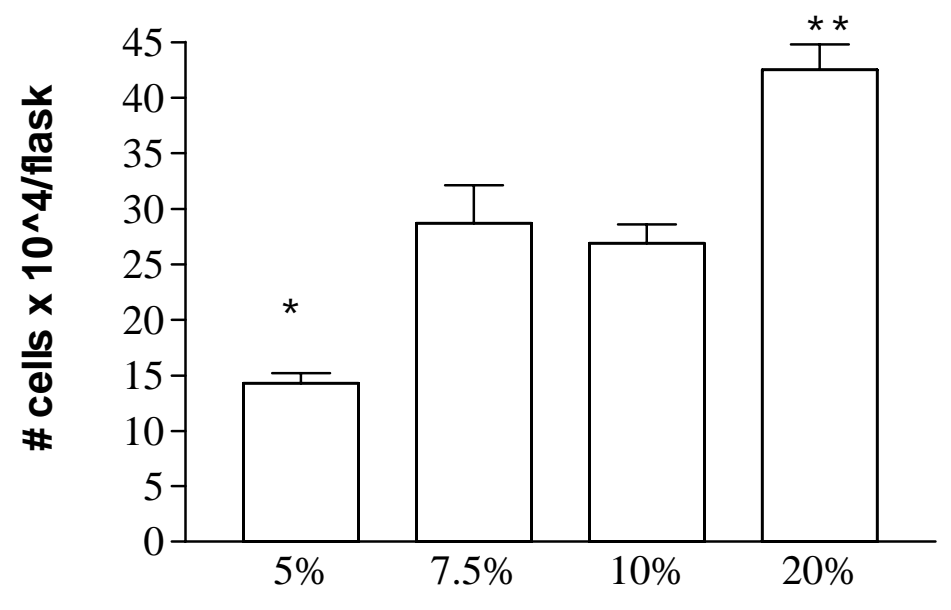

FBS

Figure 12: Adult normal guinea pig seminal vesicle smooth muscle cells were plated at 1 x $10^{4}$ cells per flask. Varying concentrations of FBS were added to the media and cells were cultured for 6 days. $n=8$.

* and **: $\mathrm{p} \leq 0.05$ compared to all other groups.

For studying the role of norepinephrine in vitro, 5\% fetal bovine serum was used. Five percent was chosen since it allowed for increased cell number and was not maximal. A maximal rate of increase in cell number due to serum concentration was to be avoided as it may have masked any changes due to adrenergic agents

In vitro cell culture studies support the role of norepinephrine in male accessory sex organ smooth muscle proliferation. Primary cultures were made from adult 
guinea pig seminal vesicle smooth muscles. Cells were then passed 5 times before plating 6 -well culture dishes at $1 \times 10^{4}$ cells per well and $6 \times 10^{4}$ cells per well.

Figure 13: The effect of plating density (1 vs. $6 \times 10^{4}$ cells/well) on $10 \mu \mathrm{M}$ phenylephrine stimulation of seminal vesicle cell culture

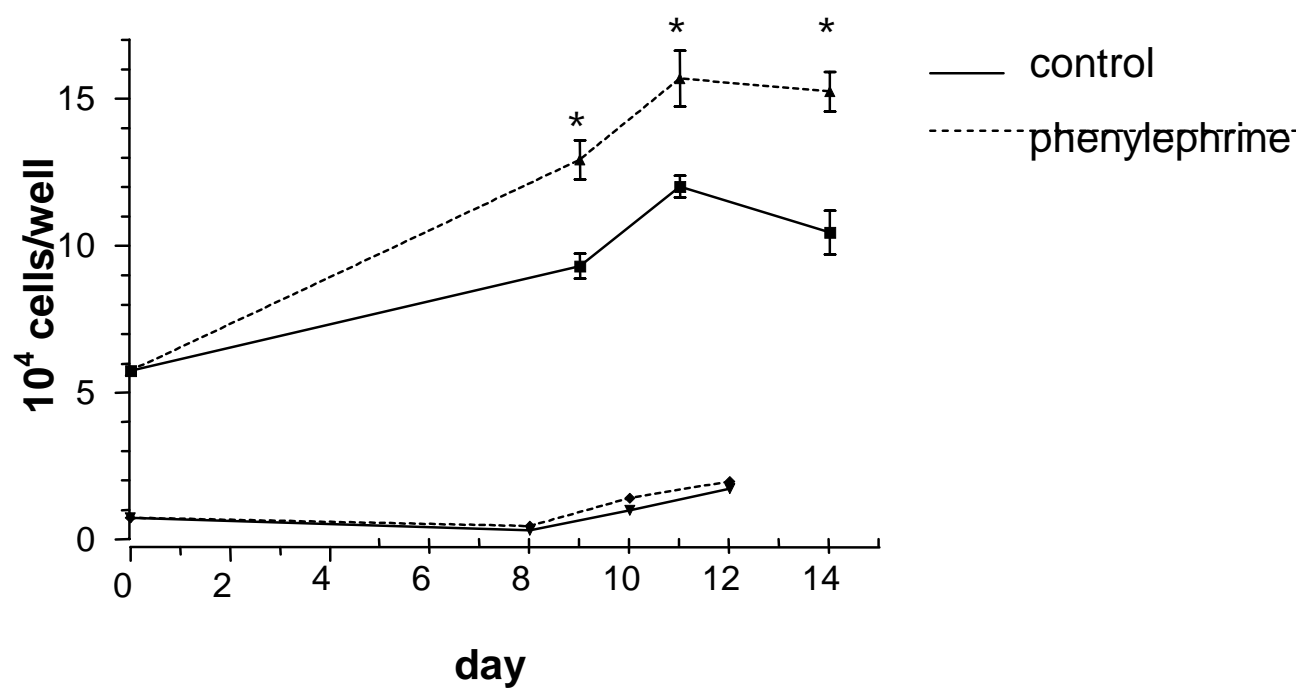

Figure 13: At low density plating, cells number showed no change from control when stimulated by $10 \mu \mathrm{M}$ phenylephrine ( $\mathrm{n}=6$ for all groups and days.) $10 \mu \mathrm{M}$ phenylephrine significantly enhanced cell number at high plating density. 6-well culture plates were used and media and adrenergic agents were changed daily.

${ }^{*} \mathrm{p} \leq 0.05$ compared to control.

Cells initially plated at the higher density of $6 \times 10^{4}$ were counted on days 9, 11, and day 14 after treatment with $10 \mu \mathrm{M}$ phenylephrine, an $\alpha_{1}$-adrenoceptor agonist, and 
compared to controls counted on the same days.

Phenylephrine stimulation increased cell number $44.2 \%$ on day $9,31.6 \%$ on day 11 and $44.6 \%$ on day 14.

Cells plated at the lower density of $1 \times 10^{4}$ cells per well showed no increase in cell number by day 8 and no difference between control and phenylephrine on day 8 as well as subsequent days. Some of the cells initially plated at the lower density were maintained to day 35, with daily media changes as was done in the earlier counts. On day 35, phenylephrine-treated cells showed a significant, almost 2-fold increase over control cells. Control cell number remained constant from day 12 using this low serum concentration. Although not further pursued here, it is possible that growth factors secreted from the cells themselves play a role in the rate of increase of cell number. 
Figure 14: Cell number increases in low density $\left(\begin{array}{l}1 \times 10^{4} \\ \hline\end{array}\right.$ cells/well) plated wells

\section{plated at $1 \times 10^{4}$ cells/well}

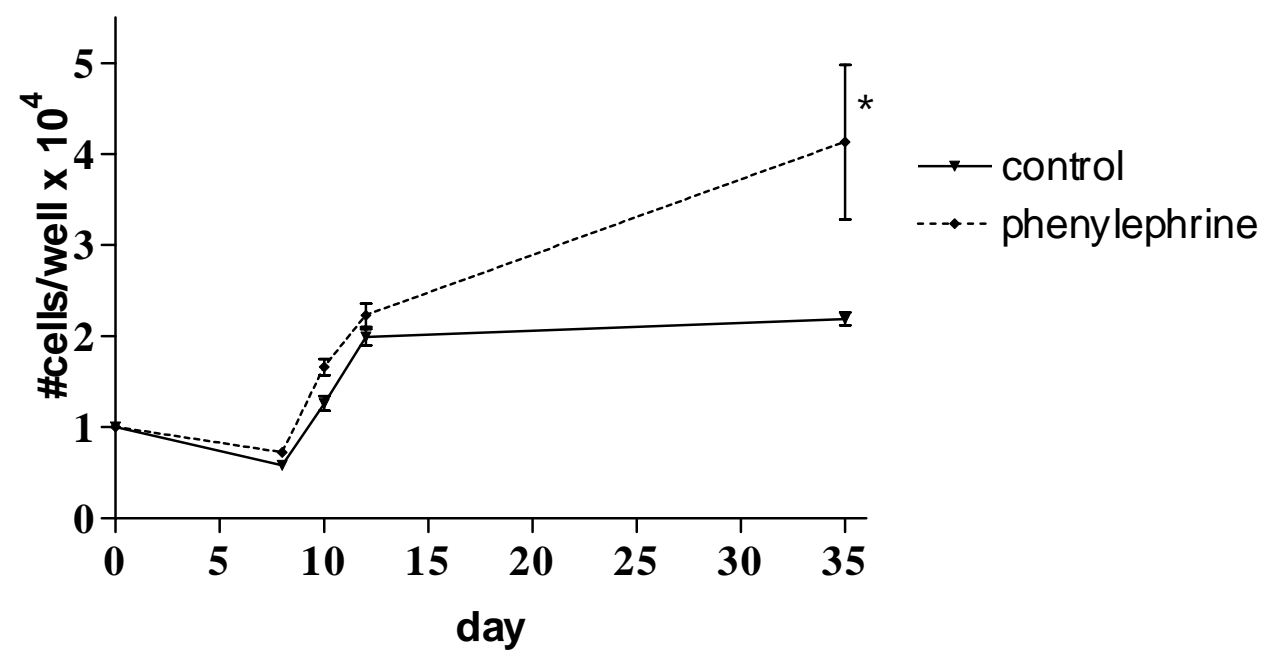

Figure 14: No difference was observed in phenylephrinetreated cells compared to control 8, 10 and 12 days postplating. With long-term maintenance (35 days), a significant difference was seen. 6-well culture plates were used. $\mathrm{n}=6$.

$* \mathrm{p} \leq 0.05$ compared to control. 
Figure 15: The Effect of Various Adrenergic Agents on 14day Seminal Vesicle Smooth Muscle Cell Culture

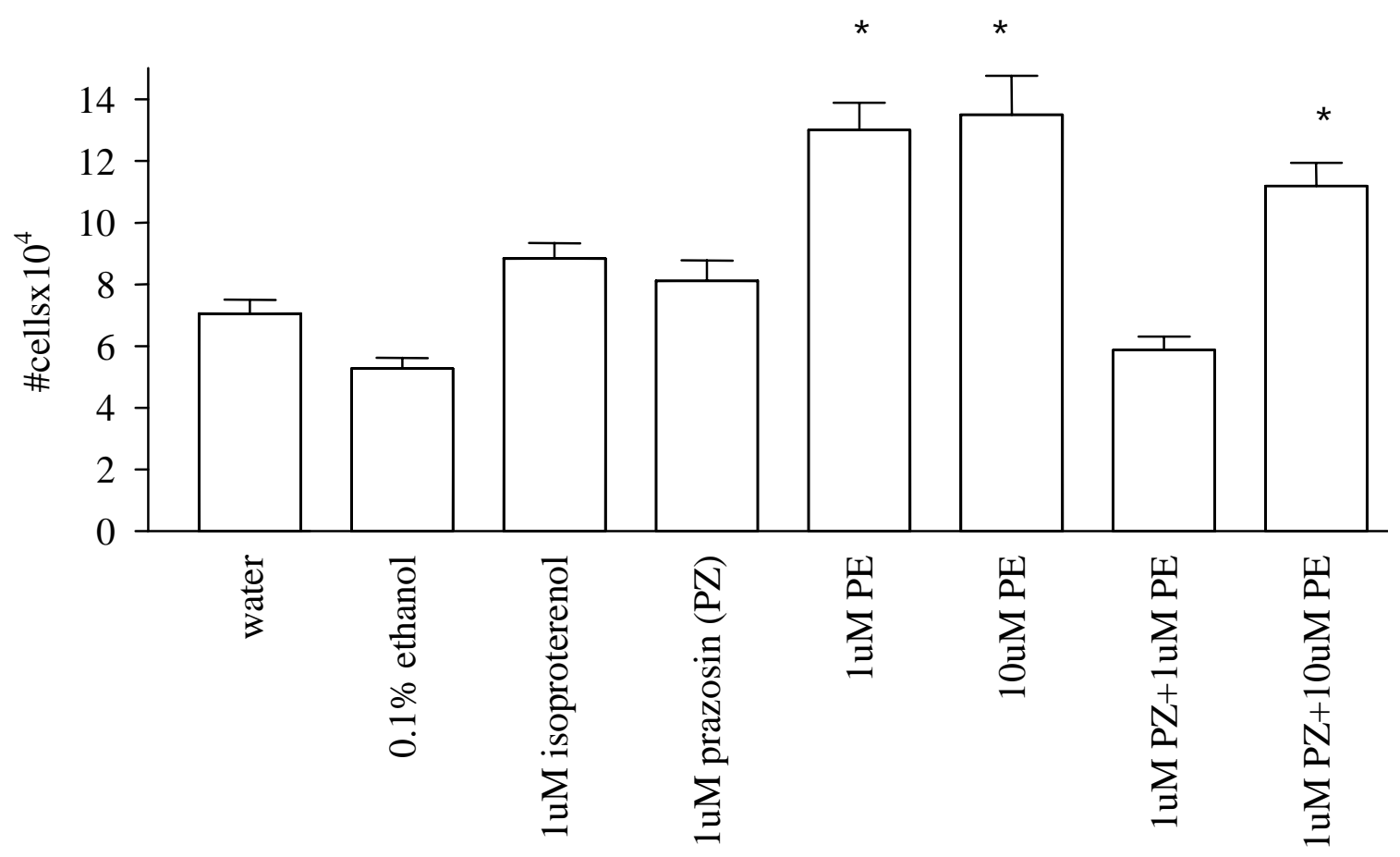

Figure 15: Increased cell number was due to $\alpha_{1}$-adrenoceptor stimulation which was blocked by prazosin, but overcome with increased phenylephrine concentration. Water was the vehicle for isoproterenol. $0.1 \%$ ethanol was the vehicle for the other agents. Cells were initially plated at $6 \mathrm{x}$ $10^{4}$ cells/well ( 6 well plates) and maintained for 14 days. Media and adrenergic agents were changed daily. $n=3$. ${ }^{*} \mathrm{p} \leq 0.05$ compared to other groups.

The use of adrenergic antagonists indicated that the increase in cell number was due to an $\alpha_{1}$-adrenoceptormediated effect. Cells exposed to $1 \mu \mathrm{M}$ isoproterenol, a $\beta$ adrenoceptor agonist, had no effect on cell number compared to its water control. Therefore, it suggested that the $\beta$ - 
adrenoceptor was not involved in the increase in cell

number. Furthermore, the effect of $1 \mu \mathrm{M}$ phenylephrine was blocked by $1 \mu \mathrm{M}$ prazosin, an $\alpha_{1}$-adrenoceptor antagonist. However, the antagonism caused by $1 \mu \mathrm{M}$ prazosin could be overcome by increasing the phenylephrine concentration to $10 \mu \mathrm{M}$. These data indicated that the $\alpha_{1}$-adrenoceptor mediated the phenylephrine-induced increase in cell number.

\section{B. Specific Aim 2:}

2. Norepinephrine did not function anti-apoptotically in seminal vesicle smooth muscle cells in prepubertal castrates treated with androgen.

Previous data have shown that adult guinea pig seminal vesicle smooth muscle exists in a terminally differentiated state in vivo that is resistant to changes in DNA in response to androgen ablation or repletion (Mariotti et al., 1992). Two findings shown above raised the possibility that elevated NE release prevented castrationinduced regression of smooth muscle cell number in adults through an anti-apoptotic mechanism. NE release in adult 
castrates was 1) as high as in androgen-treated prepubertal castrates (fig. 1) and 2) unchanged by androgen treatment (fig. 1). Therefore, adult guinea pigs were orchiectomized and treated with reserpine to determine whether norepinephrine depletion would effect a net reduction in total DNA and involve an apoptotic mechanism.

Figure 16: Norepinephrine depletion did not effect DNA in adult seminal vesicle smooth muscle

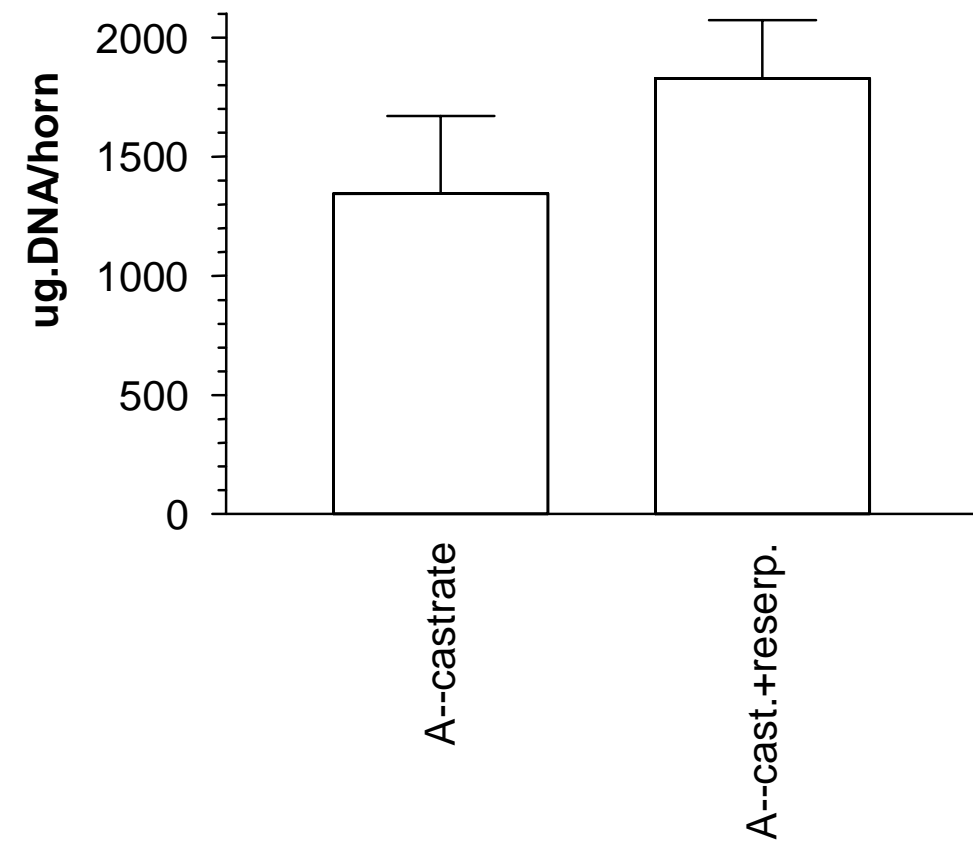

Figure 16: Depletion of norepinephrine by reserpine had no significant effect on $\mu \mathrm{g}$. DNA compared to weight-matched controls. $\mathrm{n}=4-10$ per group. 
In adult castrates, DNA was not effected by reserpine treatment, precluding the proposed subsequent analysis of apoptosis. The potential role of apoptosis was further pursued in androgen and reserpine-treated prepubertal castates which exhibited a $42.4 \%$ reduction in cell number relative to their androgen-treated control (fig. 8).

However, gel electrophoresis of nuclear extracts revealed that neither group exhibited apoptosis. That is, the characteristic apoptotic laddering from DNA oligonucleosomes was not seen in either group. Generalized heavy smearing indicating larger scale DNA degradation was also not seen, ruling out necrosis. 
Figure 17: No apoptosis was detected in norepinephrine depleted prepubertal castrates treated with androgen

$\begin{array}{llllllllllllll}1 & 2 & 3 & 4 & 5 & 6 & 7 & 8 & 9 & 10 & 11 & 12 & 13 & 14\end{array}$

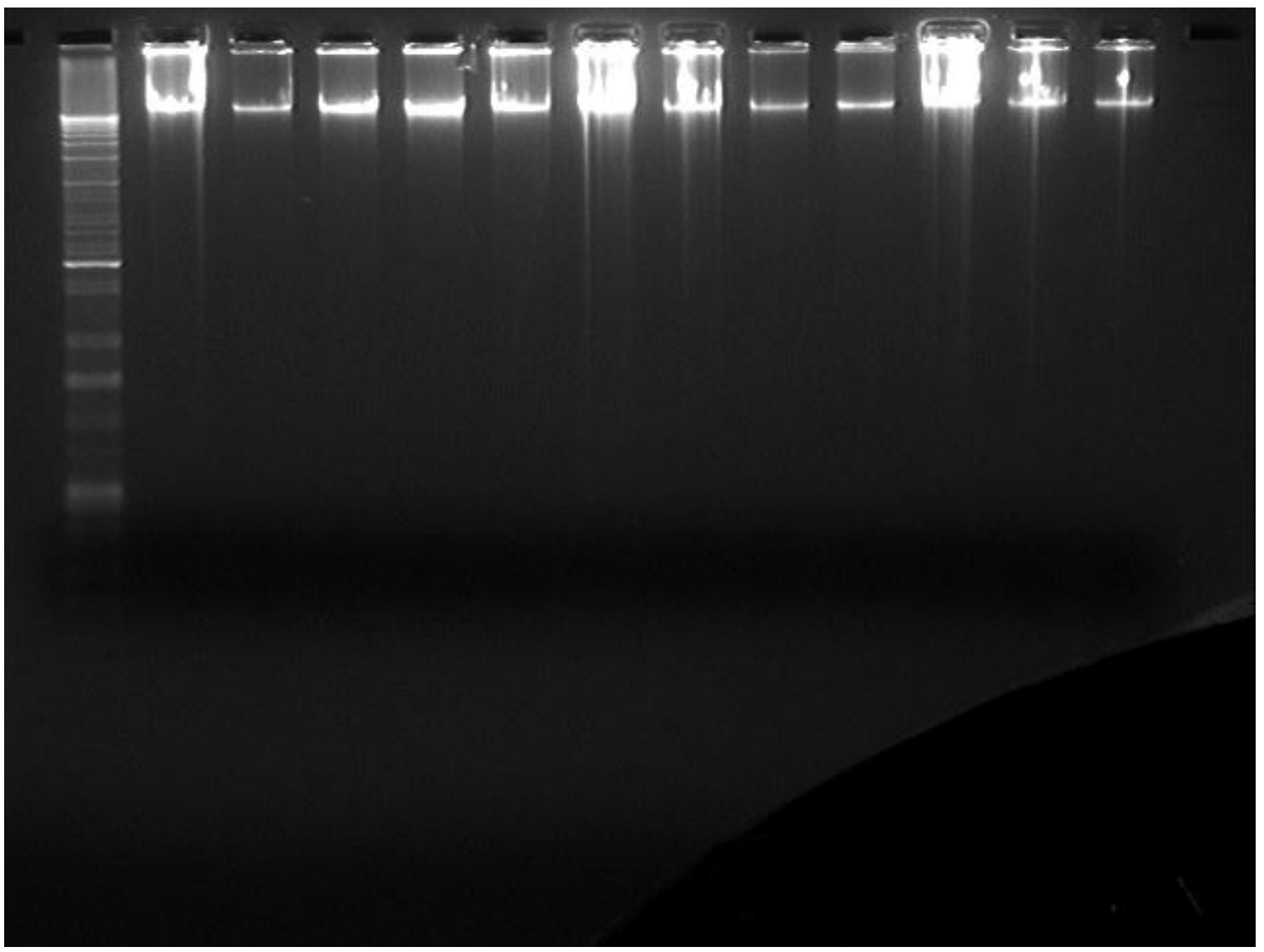

Figure 17: Lane 1 is a positive control (Kb Ladder). Lanes 2-6, and lane 13 are prepubertal castrates treated with 10 $\mathrm{mg} / \mathrm{kg}$ DHT alone. Lanes 7-12 are prepubertal castrates treated with both DHT and $0.75 \mathrm{mg} / \mathrm{kg}$ reserpine. Lane $14 \mathrm{is}$ an empty template, negative control.

It can be concluded that during five days of androgen treatment, concurrent reserpine treatement did not induce apoptosis at that point in time, despite the inhibition of androgen-induced changes in cell number. 
C. Specific Aim 3: Androgen decreased the number of norepinephrine-feedback-mediating, $\alpha_{2}$-adrenoceptors in seminal vesicle smooth muscle.

Norepinephrine was shown, in Specific Aim 2 above, to mediate smooth muscle growth in prepubertal castrates treated with DHT. A potential mechanism for increased norepinephrine release involving decreased pre-synaptic feedback by the $\alpha_{2}$-adrenoceptor was then examined. Other potential mechanisms were not pursued.

As a prelude to study of the presynaptic $\alpha_{2}-$ adrenoceptor, experiments were done to determine whether functional post-junctional $\alpha_{2}$-adrenoceptors were present. Post-junctional $\alpha_{2}$-adrenoceptors can mediate contraction and have been identified in dog vascular smooth muscle postsynaptically (Langer et al., 1980). The presence of such receptors would preclude the use of the proposed electrical field stimulation experiments in isolated organ baths to study the presynaptic feedback of endogenous norepinephrine. By using BHT-933, a post-junctional $\alpha_{2}-$ adrenoceptor agonist (Timmermans and van Zwieten, 1980), the presence of post-junctional $\alpha_{2}$-adrenoceptors was studied, using contractile response as an end-point. 
Figure 18: BHT-933 was unable to elicit post-junctional $\alpha_{2}-$ adrenoceptor-mediated contractions in adult normal guinea pig seminal vesicle smooth muscle

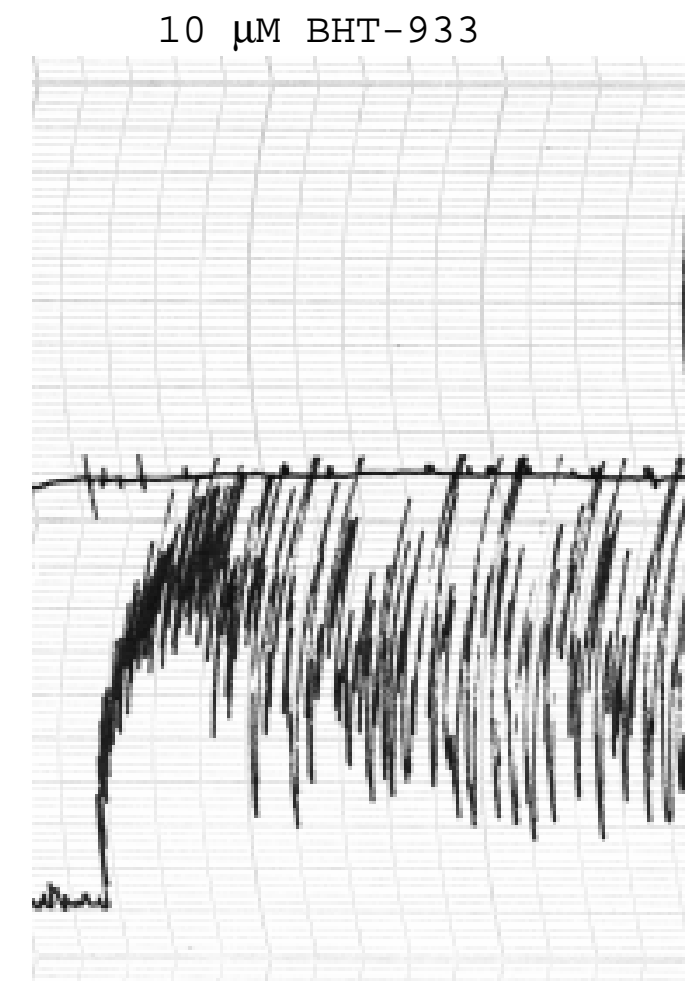

$10 \mu \mathrm{M}$ methoxamine

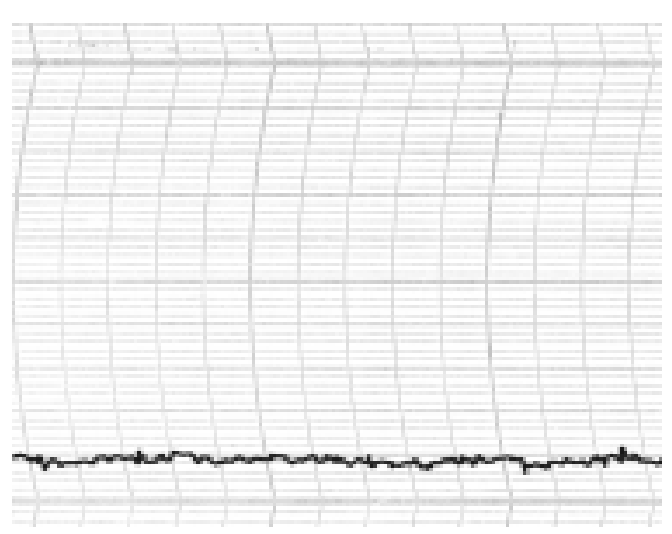

$10 \mu \mathrm{M}$ methoxamine after $30 \mathrm{~min}$.incubation with $10^{-7} \mathrm{M}$ prazosin

Figure 18: $10 \mu \mathrm{M}$ BHT-933 did not elicit a post-junctional $\alpha_{2}$-adrenoceptor mediated response. $10 \mu \mathrm{M}$ methoxamine, an $\alpha_{1}$-adrenoceptor agonist, \pm prazosin was used as a positive control in eliciting contraction. $n=4$. 
BHT-933 was unable to elicit a contractile response in seminal vesicle smooth muscle (fig. 18), even at a supramaximal concentrations of $10 \mu \mathrm{M}$ (Nielson et al., 1989; Timmermans and van Zwieten, 1980), suggesting the absence of functional post-junctional $\alpha_{2}$-adrenoceptors for this parameter. The smooth muscle tissues were then tested to confirm viability with $10 \mu \mathrm{M}$ methoxamine as a positive control, which did elicit contractions. These contractions were completely blocked by prazosin (fig. 18) .

Electrical field stimulation (EFS) studies of seminal vesicle smooth muscle contraction in the presence and absence of $1 \mu \mathrm{M}$ rauwolscine, an $\alpha_{2}$-adrenoceptor antagonist were performed. It was expected that rauwolscine would block presynaptic $\alpha_{2}$-adrenoceptor-mediated norepinephrine feedback, and thus enhance EFS-induced contractions. The working hypothesis was that in prepubertal castrate animals, androgen treatment, which caused an increase in $\mathrm{NE}$ release (fig. 1), would result in significant reductions in rauwolscine-enhanced EFS contractions relative to the prepubertal castrate control. 
Figure 19: An example of electrically field stimulated contractile tracings from isolated seminal vesicle smooth muscle tissues
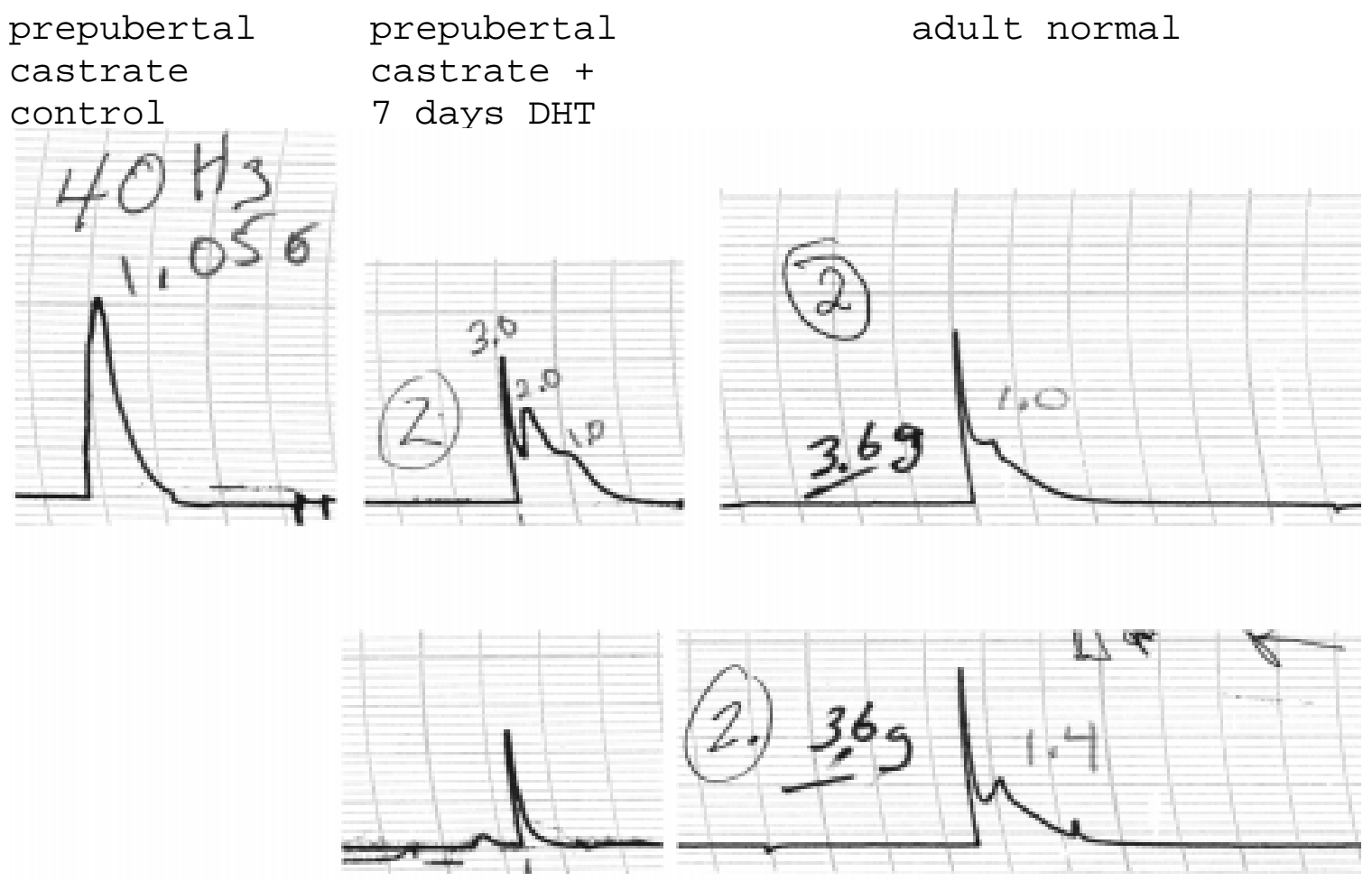

prepubertal

adult normal castrate + 7days DHT after 1 hr. incub. after $30 \mathrm{~min}$. in $1 \mu \mathrm{M}$ rauwolscine in $1 \mu \mathrm{M}$ prazosin

Figure 19: Only qualitative comparisons could be made due to differences in transducer sensitivities and tissue behavior. Tissues were stimulated at 2, 5, 10, 20, 30 and $40 \mathrm{~Hz}$ for 30 seconds with each pulse being of $0.5 \mathrm{msec}$ duration. Tracings from a $40 \mathrm{~Hz}$ stimulation are shown above. Prepubertal castrates showed only one contractile peak that occurred at the moment of stimulation and was not abolished by prazosin. The other groups had a biphasic or multiphasic response. In these groups, prazosin abolished all peaks except the initial peak. All peaks increased with increasing $\mathrm{Hz}$. Prepubertal guinea pigs weighed approx. 250 gms. Adults weighed 500-550 gms. Each group had an $n=6-8$. 
While all groups showed increasing contractile response to increasing frequency of stimulation, intergroup comparisons could not be made because the contractile responses were qualitatively different. Prepubertal castrate controls exhibited only a single contraction in both the control and rauwolscine-treated tissues that occurred immediately to stimulation. This response was not inhibited by prazosin. Adult normals, castrates, and androgen-treated castrates showed a biphasic response, and prepubertal castrates treated with dihydrotestosterone showed multiple contractile peaks. In all groups, prazosin abolished all contractile responses except the initial, very rapid upsweep of the tracing. This initial contraction has been described as being ATP-mediated in the guinea pig vas deferens (Burnstock et al., 1972; Westfall and Stitzel, 1978), and appears to be present in prepubertal castrates as well as all of the other experimental treatment groups.

In the groups whose tracings did show adrenergic, contractile peaks, $1 \mu \mathrm{M}$ rauwolscine caused enhancement to varying degrees, indicating that the pre-synaptic $\alpha_{2}-$ adrenoceptor was functional. The notable absence of the functional $\alpha_{1}$-adrenoceptor-mediated contractile response in 
prepubertal castrates prevented further use of this particular experimental design to assess changes in presynaptic $\alpha_{2}$-adrenoceptor mediated effects on $\mathrm{NE}$ release. The presence of a functional $\alpha_{1}$-adrenoceptor-mediated contractile response in prepubertal castrates after androgen-treatment, however, suggested that androgen may be important in the development of the $\alpha_{1}$-adrenoceptor. This follows evidence suggested in earlier studies that the development of $\alpha_{1}$-adrenoceptor-mediated contraction in rat vas deferens coincided with the onset of puberty and endogenous androgen production (MacDonald and McGrath, $1984)$

The effect of $\alpha_{2}$-adrenoceptor antagonism by rauwolscine on EFS overflow of norepinephrine was not studied. Preliminary studies using supramaximal stimulation (40 V, $40 \mathrm{~Hz}, 30$ seconds) in the presence of $1 \mu \mathrm{M}$ rauwolscine in 10 ml organ baths did not yield detectable norepinephrine concentrations without additional extraction techniques. Ligand binding experiments were then performed using $\left[{ }^{3} \mathrm{H}\right] \mathrm{RX} 821002$ to identify and quantify $\alpha_{2}$-adrenoceptors in seminal vesicle from normal adult males (500-550 gms). Studies to determine binding rate and protein dependence 
used $0.4 \mathrm{nM}$ of tritiated ligand, the lowest concentration to be employed in subsequent saturation analyses.

Figure 20: $\left[{ }^{3} \mathrm{H}\right] \mathrm{RX} 821002$ binding rate and protein dependence of $\left[{ }^{3} \mathrm{H}\right] \mathrm{RX} 821002-\mathrm{binding}$ in adult normal guinea pig seminal vesicle smooth muscle

\section{Binding rate}

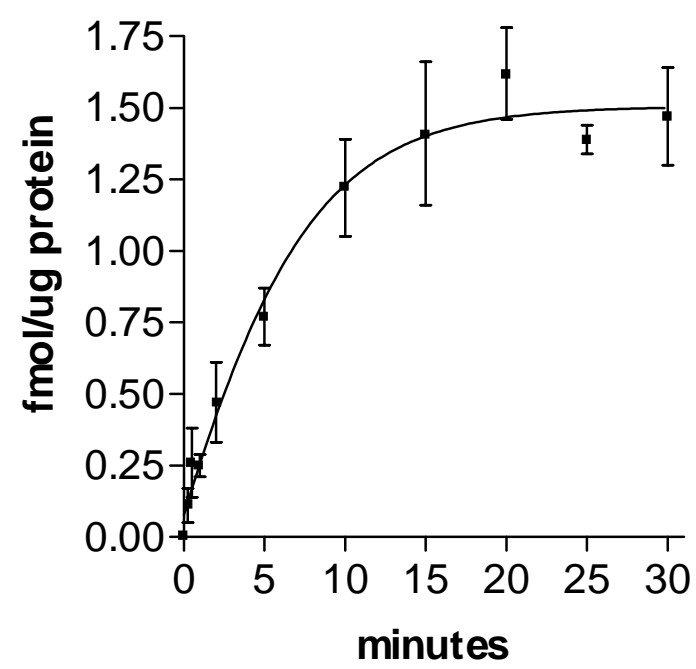

protein dep.

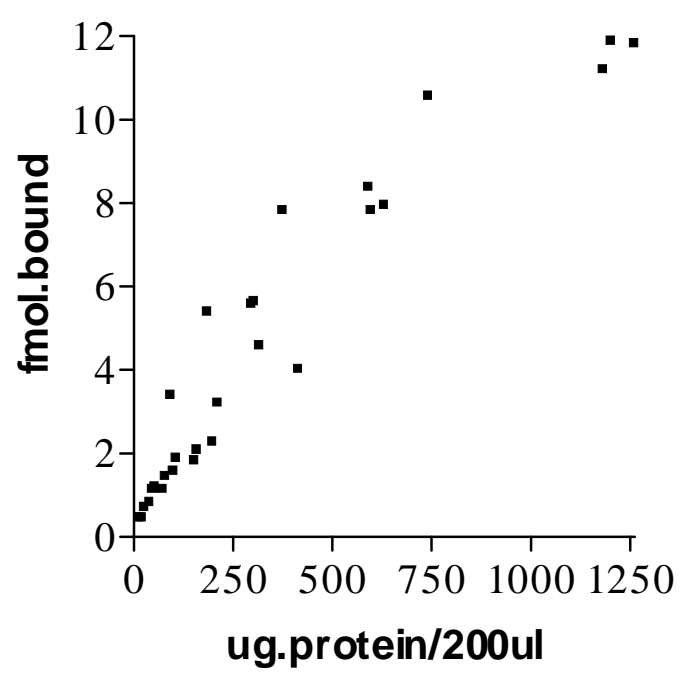

Figure 20: Binding reached equilibrium by 15 minutes, and was linearly protein dependent between 12 and $1260 \mu \mathrm{g}$ of protein/200 $\mu \mathrm{l}$ when using $0.4 \mathrm{nM}\left[{ }^{3} \mathrm{H}\right] \mathrm{RX} 821002$ in adult normal guinea pigs weighing 500-550 gms. $\mathrm{n}=4$.

Using $0.4 \mathrm{nM}\left[{ }^{3} \mathrm{H}\right] \mathrm{RX} 821002$, data plotted using the GraphPad computer program, showed that a 15 minute incubation provided for binding equilibrium. All subsequent experiments were done using 20 minute incubations. Protein dependence experiments also showed that the femtomoles of $\alpha_{2}$-adrenoceptors bound were linearly 
dependent upon the amount of protein present between 12 and $1260 \mu \mathrm{g}$ in the $200 \mu \mathrm{l}$ reaction mixture.

Binding affinity as well as the number of sites were determined using $\left[{ }^{3} \mathrm{H}\right] \mathrm{RX} 821002$ concentrations ranging from 0.40 to $9.0 \mathrm{nM} \pm 10^{-4} \mathrm{M}$ non-radioactive rauwolscine. Results were calculated using both saturation binding curves by GraphPad statistical program and its linear transformation to a Scatchard-Rosenthal plot. 
Figure 21: Saturation binding curves and Scatchard-

Rosenthal plots for the $\alpha_{2}$-adrenoceptor using [ $\left.{ }^{3} \mathrm{H}\right] \mathrm{RX} 821002$

in normal adult guinea pig seminal vesicle smooth muscle

sat. binding

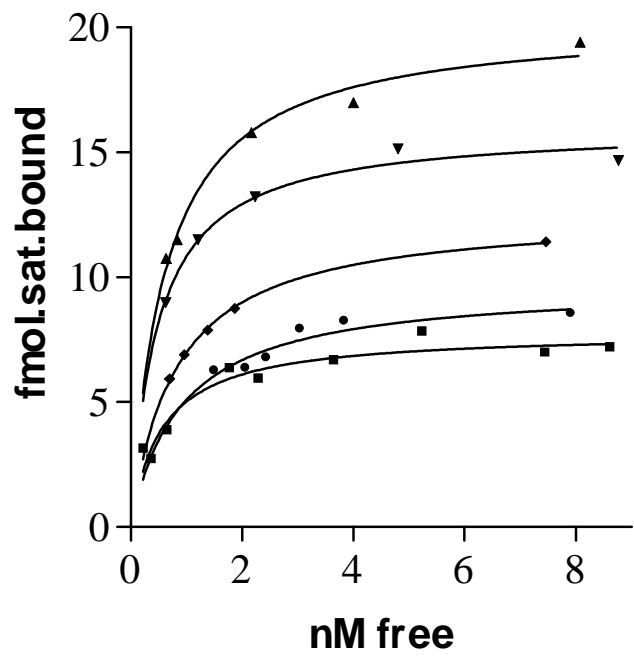

Scatchard-Rosenthal Plot

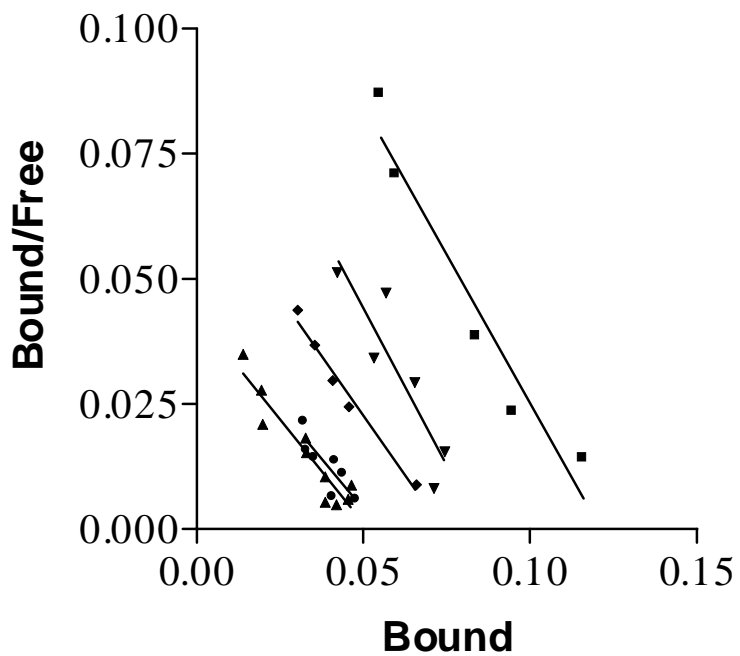

Figure 21: [ $\left.{ }^{3} \mathrm{H}\right] \mathrm{RX} 821002$ concentrations were used ranging from 0.40 to $9.0 \mathrm{nM} \pm 10^{-4} \mathrm{M}$ non-radioactive rauwolscine. $K_{d}=0.67 \pm 0.08 \mathrm{nM}$ according to the saturation binding curve and $0.65 \pm 0.08 \mathrm{nM}$ by Scatchard-Rosenthal linearization. The curves depicted reflect different amounts of protein used on each experimental day. When corrected for protein, $\mathrm{B}_{\max }=11.78 \pm 1.62 \mathrm{fmol} / \mathrm{mg}$. Adult normal guinea pigs weighing 500-550 gms were used.

The saturation binding curve showed $a K_{d}=0.67 \pm 0.08$

nM. The Scatchard-Rosenthal plot gave a $K_{d}=0.65 \pm 0.08$

nM. When corrections for the varying protein amounts used on the experimental days were made, the number of $\alpha_{2}-$ adrenoceptor binding sites $\left(B_{\max }\right)$ was determined to be 11.78 $\pm 1.62 \mathrm{fmol} / \mathrm{mg}$ membrane protein. 
$\mathrm{K}_{\mathrm{d}}$ comparisons can only be made to other tissues and species since there were no other known studies using RX821002 in guinea pig seminal vesicle smooth muscle or any other smooth muscle specimen. From research employing rat cortex, spleen and kidney, and guinea pig kidney (Erdbrugger, 1995), the $K_{d}$ values were $0.6 \pm 0.0,0.4 \pm 0.1$, $1.5 \pm 0.8$, and $4.3 \mathrm{nM}$ respectively. The $0.67 \mathrm{nM} \mathrm{K}_{\mathrm{d}}$ determined in guinea pig seminal vesicle smooth muscle is within the reported range.

Competition assays using 5 nM $\left[{ }^{3} \mathrm{H}\right] \mathrm{RX} 821002$, a saturating concentration, were done to characterize the receptor subtype present. 
Table 2: Comparison of IC50's and affinity $\left(\mathrm{K}_{\mathrm{i}}\right)$ drugs for the $\alpha_{2}$-adrenoceptor, using $5 \mathrm{nM}\left[{ }^{3} \mathrm{H}\right] \mathrm{RX} 821002$ in adult normal guinea pig seminal vesicle smooth muscle

Drug

RX821002

Phentolamine

Clonidine

Rauwolscine

Prazosin
IC50

$0.67 \mathrm{nM}\left(\mathrm{K}_{\mathrm{d}}\right.$ from saturation experiments)
$26.00 \mathrm{nM}$

$36.63 \mathrm{nM}$

$49.63 \mathrm{nM}$

$4136 \mathrm{nM}$

Table 2: IC50's were determined from hand-drawn, log-logit inhibition plots, and were confirmed by curves drawn by GraphPad computer program. $\mathrm{K}_{\mathrm{i}}^{\prime} \mathrm{s}$ were calculated using the IC50's derived by the handdrawn curves and the Cheng and Prusoff equation, and were also confirmed by GraphPad. Adult normal guinea pigs weighing 500-550 gms were used. $\mathrm{n}=4$.

The rank order of potency for the drugs employed above is similar to the rank order of drugs quantified in other tissues with $\alpha_{2 D}$-adrenoceptors (Table 3). Qualitatively, the $\alpha_{2 D}$-adrenoceptor differs from subtypes $A, B$, and $C$ in that phentolamine was a more potent antagonist than rauwolscine (Table 3 , below). 
Table 3: Ratio of $K_{i}$ of competetitor to respective $K_{d}$ of RX821002 in experiments done in guinea pig seminal vesicle smooth muscle compared to other tissues with $\alpha_{2 \mathrm{D}}-$ adrenoceptors

\begin{tabular}{|c|c|c|c|c|c|c|c|}
\hline \multirow[b]{2}{*}{ Drug } & \multirow{2}{*}{$\begin{array}{l}\text { seminal vesicle } \\
\text { smooth muscle }\end{array}$} & \multicolumn{2}{|c|}{ bovine } & & \multicolumn{3}{|c|}{ human clones } \\
\hline & & $\operatorname{iris}^{\mathrm{a}}$ & pineal $^{\mathrm{b}}$ & cloned $2 \mathrm{D}^{\mathrm{b}}$ & $2 \mathrm{~A}$ & $2 \mathrm{~B}$ & $2 \mathrm{C}$ \\
\hline phentolamine & 38.8 & 48.3 & 9.4 & 9.1 & 14.1 & 6.47 & 35.1 \\
\hline rauwolscine & 74.1 & 85.8 & 28.8 & 35.2 & 1.1 & 0.35 & 0.35 \\
\hline prazosin & 6173 & 26241 & 4151 & 1648 & 1041 & 29.5 & 29.7 \\
\hline
\end{tabular}

Table 3: a. data from Bylund (1997)

b. data from O'Roarke (1994) and Simmonneaux(1991)

c. data from Bylund (1992) and O'Roarke (1994)

5-hydroxytrypamine (5HT) was used to determine if

$\left[{ }^{3} \mathrm{H}\right] \mathrm{RX} 821002$ had any interaction with serotonin receptors.

5HT at concentrations as high as $1 \mu \mathrm{M}$ had no effect on

binding. Since RX821002 has been shown to bind to nonadrenergic imidazoline receptors in rabbit kidney basolateral membranes (Coupry et al., 1987), clonidine was used to rule out the binding of imidazoline sites. The notable finding was that the Ki ratio of phentolamine to clonidine was much lower in $\alpha_{2}$-adrenoceptor sites than imidazoline sites in human brain cortex (1.52 versus 17.01) (Miralles et al., 1993). In the seminal vesicle smooth muscle the clonidine to phentolamine $\mathrm{K}_{\mathrm{i}}$ ratio was 1.38 , indicating that relative to imidazoline sites, [ $\left.{ }^{3} \mathrm{H}\right] \mathrm{RX} 821002$ preferentially bound to the $\alpha_{2}$, subtype $D$, adrenoceptor. 


\begin{abstract}
Using a single 5 nM saturating concentration of $\left[{ }^{3} \mathrm{H}\right] \mathrm{RX} 821002$, experiments utilized seminal vesicle smooth muscle preparations derived from the four treatment groups to assess potential changes in the maximal number of binding sites relative to known changes or lack thereof in $\mathrm{NE}$ release.
\end{abstract}

Figure 22: Number of $\alpha_{2 D}$-adrenoceptor binding sites $\left(B_{\max }\right)$ in seminal vesicle smooth muscle among various treatment groups.

\title{
Bmax
}

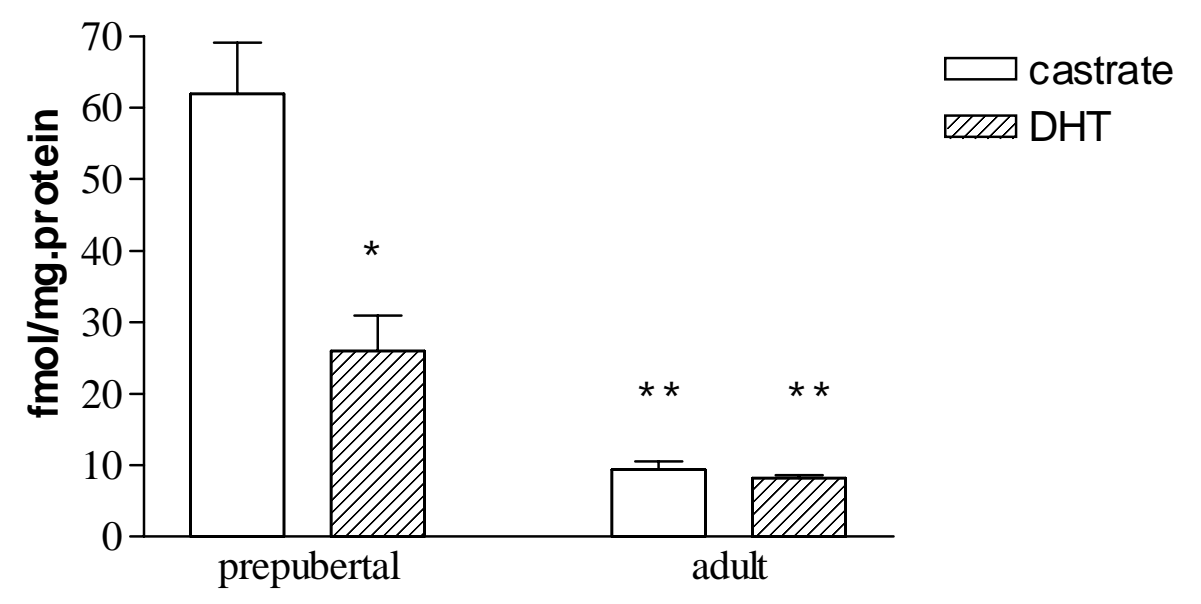

Figure 22: The number of $\alpha_{2 D}$-adrenoceptor binding sites was reduced with androgen exposure in prepubertal seminal vesicle smooth muscle and was unchanged by androgen in adult tissues. The number in parentheses is the ratio of $\alpha_{2}$-adrenoceptor $B_{\max }$ to norepinephrine released (DHPG/NE) Prepubertal guinea pigs weighed approx. 250 gms. Adults weighed 500-550 gms. Four separate experiments were done using multiple animals in each group.

${ }^{*} \mathrm{p} \leq 0.05$ compared to prepubertal castrate control.

${ }^{*} \mathrm{p} \leq 0.05$ compared to prepubertal castrate control and prepubertal DHT-treated. 
The lack of contraction by BHT-933 (fig. 18) could be assumed to be indicative of an absence of post-synaptic, contractile-mediating $\alpha_{2}$-adrenoceptors. Therefore, it could be implied that any quantification of $\alpha_{2}$-adrenoceptors by RX821002 may be more closely correlated with norepinephrine-feedback-mediating $\alpha_{2}$-adrenoceptors. It appeared that androgen down-regulated the number of $\alpha_{2}-$ adrenoceptors during the proliferative, prepubertal phase in which norepinephrine release is induced by androgen. In adulthood, the number of norepinephrine-feedback-mediating $\alpha_{2}$-adrenoceptors remained low and androgen-resistant while norepinephrine release was sustained at high levels equivalent to androgen-treated prepubertal castrates. This androgen-induced decrease in the norepinephrine-feedbackmediating, $\alpha_{2}$-adrenoceptor may be mechanistic for the increase in norepinephrine release observed in response to androgens in the prepubertal seminal vesicle (fig. 1). 


\section{Discussion}

The goal of this research was to understand the role of norepinephrine in the growth of male accessory sex organ smooth muscle. The results showed that androgen-induced post-ganglionic norepinephrine release (fig. 1) in seminal vesicle smooth muscle (fig. 3) and was involved in the regulation of proliferation (fig. 8). This increased norepinephrine release was accompanied by down-regulation of the $\alpha_{2}$-adrenoceptor population (fig. 22). This discussion will more closely explore these findings, suggest future directions stemming from this data, and examine the potential therapeutic significance.

In prepubertal castrates treated with androgen, smooth muscle DNA increased 138\% over control while epithelial DNA increased 759\% (fig. 8). The androgen-induced increase in NE release follows the time course of DNA synthesis (Mariotti et al., 1992) and first significant increase in total DNA. Depletion of norepinephrine by $\leq 99 \%$ of control by reserpine reduced the smooth muscle increase to 37\% over control without disrupting the androgen-induced proliferation of the cholinergically innervated epithelium. This suggests that norepinephrine mediates the androgeninduced proliferative response in smooth muscle. However, 
it did not indicate whether this effect was due to enhanced proliferation or decreased apoptosis.

It was hypothesized that the inability of castration to reduce cell number in adult smooth muscle (Mariotti et al., 1992) may have been due to the unexpected finding of the sustained, androgen-resistant elevation in norepinephrine release (fig. 1). If norepinephrine were anti-apoptotic, reserpine-treatment would enhance apoptosis and decrease DNA. However, depletion of norepinephrine in adult castrates by reserpine did not decrease cell number relative to controls (fig. 16). In androgen-treated prepubertal castrates, treated concurrently with reserpine, there was a decrease in DNA compared to androgen-treated controls (fig. 17). However, agarose gel electrophoresis failed to detect any apoptotic laddering. Because apoptotic products are quickly phagocytized (Lockshin and Beaulaton, 1974), it is possible that apoptosis had occurred at an earlier time point and thus was undetected on the fifth day of treatment. Gel electrophoresis is also limited in detecting small numbers of apoptotic nuclei. If apoptosis were to be further examined, double staining to detect both in situ end labeling (ISEL) and chromatin condensation should be employed (Tatton et al., 1998). The onset of androgen-induced DNA synthesis is at day 3 of treatment and 
increases in graded fashion to peak on day 7. Androgeninduced increases in total DNA were first detected on day 5 (based on analyses from days 3, 5, and 7 of androgen treatment) (Mariotti et. al, 1992). Therefore, the effect of reserpine on androgen-induced increases in cell number probably reflects an anti-proliferative effect. Further pursuit of this could explore cell cycle dependent markers of proliferation such as Ki-67, PCNA or MIB-1 (Schipper et al., 1998) in response to androgen \pm reserpine treatment. Although there is sustained elevation of norepinephrine release (fig. 1), seminal vesicle smooth muscle from orchiectomized adults failed to exhibit any change in DNA in response to androgen repletion (Mariotti et al., 1992). This androgen-resistant elevation of norepinephrine release in adulthood (fig. 1) combined with the relatively high PKC activity (Mariotti et al., 1992), that is also androgen-resistant, indicate that increased norepinephrine release became uncoupled from the mitogenic response at or before the level of stable activation of PKC. Specifically, with the onset of androgen-exposure in prepubertal castrates, seminal vesicle smooth muscle norepinephrine release was upregulated and maintained into adulthood when it was androgen-resistant (fig. 1). PKC was stablely activated then down regulated in androgen-treated 
prepubertal castrates. However, in adulthood, PKC returns to the elevated, prepubertal castrate control levels in association with differentiation to an amitotic state (Mariotti et al., 1992). This uncoupling of increased norepinephrine release from PKC activation and subsequent depletion appears to be a critical event in the resistance to proliferation demonstrated in adult smooth muscle. Future investigation focusing on the mechanism of PKC resistance to $\alpha_{1}$-adrenoceptor stimulation should provide pertinent information about the normal terminal differentiation process of this androgen sensitive smooth muscle.

Prepubertally, before uncoupling of norepinephrine and PKC occurs, norepinephrine depletion by reserpine can prevent the androgen-induced down-regulation of $\mathrm{PKC}$ (fig. 10). Androgen down-regulated $\mathrm{PKC} \alpha$ in prepubertal castrates (fig. 11), but in adulthood, the $\alpha$-isozyme did not return to prepubertal castrate control levels as has been demonstrated with PKC (Mariotti et al., 1992). However, it is possible that this discrepancy is due to differences in quantification methods. Immunochemilumiscence was employed to determine isozyme quantities while enzymatic activity was employed to quantify PKC. 
The androgen-dependent down-regulation of $\alpha_{2}-$ adrenoceptors (fig.22) may be a potential mechanism for increased norepinephrine release. However, whether these analyses actually represent pre-synaptic $\alpha_{2}$-adrenoceptors that mediate the feedback inhibition of norepinephrine release, remains to be determined. Studies of BHT-933 effects failed to identify post-junctional $\alpha_{2}$-adrenoceptor mediated smooth muscle contraction (fig. 18), but the failure to detect these post-junctional receptors does not rule out extraneuronal binding sites. Future studies should be pursued to determine whether a cause and effect relationship exists between the increased norepinephrine release and decreased $\alpha_{2}$-adrenoceptor population during growth of smooth muscle cells. Ex vivo electrical field stimulation studies to measure increased norepinephrine release under conditions in which $\alpha_{2}$-adrenoceptor agonist and antagonist effects can be quantified should provide more relevant insight into the role of the pre-synaptic receptor and norepinephrine release. Pursuit of these experiments may require the use of reuptake inhibitors and an organ bath designed with minimal volume to allow for norepinephrine measurement with graded electrical field stimulation rather than supramaximal and prolonged 
stimulation commonly employed for these types of experiments (LaPierre et al., 1993; Ventura et al., 1998).

A major area for future examination is the potential role of the extracellular matrix in proliferation. The cell culture experiments performed here suggest extracellular factors may be involved. In vivo adult smooth muscle does not proliferate in response to androgen and the elevated endogenous release of norepinephrine. Yet, adult seminal vesicle smooth muscle cells proliferated in culture and were sensitive to the mitogenic effects of phenylephrine (fig. 13, 14, and 15). Cell number also increased at varying rates that appear to be dependent upon the plating density and confluence (fig. 13 and 14).

This change to a proliferative state in culture may be due to a decrease in anti-proliferative extracellular matrix heparan sulfate proteoglycans. Neonatal or neointimal matrices have been shown to stimulate vascular smooth muscle cell growth more efficiently than matrix from adult cells (Hein et al., 1996). This growth was further increased by the enzymatic digestion of extracellular matrix heparan sulfate (Hein et al., 1996). Heparan sulfate proteoglycans have the potential to function as growth inhibitors (Castellot et al., 1981; Bingley et al., 1998) in vascular smooth muscle cell cultures and can 
prevent neointimal formation in vivo (Bingley et al., 1998). An eight-fold greater anti-proliferative potency was measured for cell surface heparan sulfate proteoglycans extracted during confluence as compared to the exponential growth or postconfluent phases (Fritze et al., 1985). While the anti-proliferative effect of heparan sulfate has not been clearly elucidated, heparin, a molecule closely related to heparan sulfate, can inhibit PKC activity in intact cells (Feige et al., 1989). It has also been shown in mixed micellar assays that heparan sulfate is a weak inhibitor of PKC (Herbert and Maffrand, 1991). These observations raise the possibility that the resistance in vivo to proliferation in adult seminal vesicle smooth muscle, which involves PKC resistance to $\alpha_{1}$-adrenoceptor stimulation, may be linked to the expression of cell surface anti-proliferative heparan sulfate proteoglycans. Lastly, the possible therapeutic significance of this work should be recognized. Depletion of norepinephrine by reserpine in vivo in prepubertal castrates selectively perturbed the androgen-induced increase in smooth muscle mass and DNA (fig. 8). This, along with other evidence accrued in this work, indicates that norepinephrine does indeed play an obligatory role in androgen-induced proliferation. Importantly, only the smooth muscle was 
inhibited. The epithelium was not effected by reserpine. This is the first demonstration of selective antagonism of androgen-induced increases in DNA in accessory sex organ smooth muscle. While systemic reserpine treatment could not be used therapeutically for BPH due to multiple systemic adverse effects, the principle has been established that it is pharmacologically feasible to inhibit androgen-induced growth of seminal vesicle smooth muscle without perturbing the epithelium. Future studies should be performed to determine whether the inhibition of the proliferative response by short-term reserpine treatment in the presence of sustained androgenic stimulation is irreversible. Selective inhibition of the mitogenic response without antagonism of the differentiating effects of androgen may result in irreversible and premature cessation of smooth muscle growth. This experiment could be particularly enlightening regarding the future development of short term therapies in young adults that could prevent symptomatic BPH in men 60 years of age and older.

In addition, if $\alpha_{2}$-adrenoceptor agonists decrease norepinephrine release and inhibit androgen-induced smooth muscle proliferation, attempts could be made to pharmacologically upregulate the expression of the pre- 
synaptic, norepinephrine-feedback-mediating $\alpha_{2}$-adrenoceptor. Understanding the sequencing of the promoter region of the $\alpha_{2}$-adrenoceptor gene could lead to the rational development of ligands to possibly maintain irreversible expression at high levels. Theoretically, such compounds may include neurosteroids that could selectively upregulate presynaptic $\alpha_{2}$-adrenoceptor expression without stimulating androgen receptor mediated male accessory sex organ smooth muscle growth. For example, progesterone has been found to be derived from rat glial cells in culture (Jung-Testas et al., 1989) and functions to modulate GABAergic transmission in the central nervous system (Mahesh et al., 1996). Hammond (1978) has identified progesterone in the human prostate at concentrations $(0.39 \pm 0.07 \mathrm{ng} / \mathrm{g}$ tissue) in the same range as the biologically active androgens, testosterone $(0.25 \pm 0.04 \mathrm{ng} / \mathrm{g}$ tissue) and dihydrotestosterone (1.22 $\pm 0.14 \mathrm{ng} / \mathrm{g}$ tissue). However, no biological role of this steroid in male accessory sex organ has been elucidated to date. The idea that endogenous steroids with neurospecific effects may exist within male accessory sex organ is intriguing and worthy of experimental pursuit. 


\section{References}

Allo SN, Carl LL, Morgan HE: Acceleration of growth of cultured cardiomyocytes and translocation of protein kinase C. Amer. Journ. Physiol. 263: C319-C325. 1992 .

Al-Zuhair AG, Gosling JA, Dixon JS: Observations on the structure and autonomic innervation of the guinea pig seminal vesicle and ductus deferens. J. Anat. 120: 81-93. 1975.

Al-Zuhair AG, Gosling JA, Dixon JS: Light and electron microscopic studies on the intrinsic inneration of the guinea pig seminal vesicle following selective axotomy. J. Anat. 124: 615-25. 1977 .

Andersson KE, Lepor $\mathrm{H}$, Wyllie MG: Prostatic $\alpha_{1}-$ adrenoceptors and uroselectivity. Prostate 30: 20215. 1997

Arrighi HM et al: Natural history of benign prostatic hypertrophy and risk of prostatectomy: The Baltimore Longitudinal Study of Aging .

Urol [Suppl] 38:4, 1991 .

Asaoka Y, Nakamura SI, Yoshida K., Nishizuka Y: Protein kinase $C$, calcium and phospholipid degradation. Trends Biochem. Sci. 17: 414-417. 1992.

Belis JA, Blume CD, Mawhinney MG: Androgen and estrogen binding in male guinea pig accessory sex organs. Endocrinology 101: 726-40. 1976.

Bertler A, Hillarp NA and Rosengren E: Effect of reserpine on the sotrage of new-formed catecholamines in the adrenal medulla. Acta Physiol. Scand. 52: 44-8. 1961.

Bingley JA, Hayward IP, Campbell JH, Campbell GR: Arterial heparan sulfate proteoglycans inhibit vascular smooth muscle cell proliferation and phenotype change in vitro and neointimal formation in vivo. J. Vasc. Surg. 28: 308-18. 1998 . 
Bouvier LF and DeVita CJ: The Baby Boom: Entering Midlife Population Bulletin Vol 46, No. 3 (Washington, D.C.: Population Reference Bureau Inc.) 1991.

Bradford MM: A rapid and sensitive method for the quantitation of microgram quantities of protein utilizing the principle of protein-dye binding. Anal.Biochem. 72: 248-254. 1976.

Brooks G, Wilson R, Dooley $T$, Goss M, Hart I: Protein kinase $\mathrm{C}$ down-regulation and non-transient activation correlates with melanocyte growth. Cancer Res. 51: 3281. 1991.

Brown DA, Docherty JR, French AM, MacDonald A, McGrathn JC, Scott NC: Separation of adrenergic and non-adrenergic contractions to field stimulation in the rat vas deferens. Br. J. Pharmac. 79: 379-393. 1983.

Bruchovsky $N$ and Wilson JD: The conversion of testosterone to $5 \alpha$-androstan-17 $\beta$-ol-3-on3 by rat prostate in vivo and in vitro. J. Biol. Chem. 243: 2012. 1968.

Brunk CF, Jones KC, James TW: Assay for nanogram quantities of DNA in cellular homogenates. Anal. Biochem. 92: 497-500. 1979 .

Burke WJ, Kristal BS, Yu BP, Li SW, Lin TS: Norepinephrine transmitter metabolite generates free radicals and activates mitochondrial permeability transition: a mechanism for DOPEGAL-induced apoptosis. Brain Res. 787: $328-32$. 1998 .

Burke WJ, Schmitt CA, Miller C., Li SW: Norepinephrine transmitter metabolite induces apoptosis in differentiated rat pheochromocytoma cells. Brain Res. 760: 290-3. 1997.

Burnstock G, Dumsday B, and Smythe A: Atropine resistant excitation of the urinary bladder: the possibility of transmission via nerves releasing a purine nucleotide. Br. J. Pharmacol. 44: 451-61. 1972. 
Bustamante D, Lara H, Belmar $\mathrm{J}$ : Changes of norepinephrine levels, tyrosine hydroxylase and dopamine-betahydroxylase activities after castration and testosterone treatment in vas deferens of adult rats. Biol. Reprod. 40: 541-548. 1989.

Bylund DB: Subtypes of the $\alpha_{1}$ - and $\alpha_{2}$-adrenergic receptors. FASEB J. 6: 832-9. 1992 .

Bylund DB, Regan JW, Faber JE, Hieble JP, Triggle CR, Ruffolo RR: Vascular $\alpha$-adrenoceptors: from the gene to the human. Can. J. Physiol. Pharmacol. 73: 533543. 1995 .

Castellot JJ Jr., Addonizio ML, Rosenberg R, Karnovsky MJ: Cultured endothelial cells produce a heparinlike inhibitor of smooth muscle cell growth. J. Cell Biol. 90: $372-79.1981$.

Christensen LW and Clemens LG: Intrahypothalamic implants of testosterone or estradiol and resumption of masculine sexula behavior in longterm castrated male rats. Endocrinology, 95: 984. 1974.

Chung LW, Matsuura J, Runner MN: Tissue interactions and prostatic growth. I. Induction of adult mouse prostatic hyperplasia by fetal urogenital sinus implants. Biol Reprod. 31: 155-63. 1984.

Communal C, Singh $K$, Pimentel DR, Colucci WS: Norepinephrine stimulates apoptosis in adult rat ventricular myocytes by activation of the ssadrenergic pathway. Circulation 98: 1329-34. 1998.

Convents A, Convents D, DeBacker JP, DeKeyser J, and Vauquelin G: High affinity binding of $\left[{ }^{3} \mathrm{H}\right]-r a u w o l s c i n e$ and $\left[{ }^{3} \mathrm{H}\right]-\mathrm{RX} 781094$ to $\alpha_{2}$-adrenergic receptors and nonstereoselective sites in human and rabbit cortex membranes. Biochem. Pharmac. 38: 455-63. 1989.

Coupry I, Podevin RA, Dausse JP, Parini A: Evidence for imidazoline binding sites in basolateral membranes from rabbit kidney. Biochem. Biophys. Res. Commun. 147: 1055-60. 1987 . 
Cunha GR: The role of androgens in the epitheliomesenchymal interactions involved in prostatic morphogenesis in embryonic mice. Anat Rec 175:87-96, 1973.

Cruise JL, Knechtle SJ, Bollinger RR, Kuhn C, Michalopoulos GK: $\quad \alpha_{1}$-adrenergic effects and liver regeneration. Hepatology 7: 1189-94. 1987.

Cubeddu LX, Barnes E, Weiner N: Release of norepinephrine and dopamine- $\beta$-hydroxylase by nerve stimulation: I. Role of neuronal and extraneuronal uptake and of alpha presynaptic receptors. J. Pharm. Exp. Therap. 190: $431-50.1974$.

Cubeddu LX, Weiner N: Release of norepinephrine and dopamine- $\beta$-hydroxylase nerve stimulation: V. Enhanced release associated with a granular effect of a benzoquinolizine derivative with reserpine-like properties. J. Pharm. Exp. Therap. 193: 757-74. 1975.

Debiec-Rychter M, Asgari $K$, Jones RF, Grignon DJ, Haas GP, Wang CY: Xenografts of human benign prostatic hyperplasia tissues in the nude mouse.

In vivo 8: 449-50. 1994.

Decock JBJ, Gillespie-Brown J, Parker PJ, Sugden PH, Fuller SJ: Classical, novel and atypical isoforms of PKC stimulate $\mathrm{ANF}$ - and $\mathrm{TRE} / \mathrm{AP}-1$-regulated-promoter activity in ventricular cardiomyocytes. FEBS Letters. 356: 275-278. 1994 .

DeKlerk DP, Coffey DS: Qualitative determination of prostatic epithelial and stromal hyperplasia by a new technique: biomorphometrics.

Invest. Urol. 16: 240-5. 1978.

Deming CL and Wolf JS: The anatomical origin of benign prostatic enlargement. J. Urol. 42: 566. 1939.

Deupree JD, Hinton KA, Cerutis R, Bylund DB: Buffers differentially alter the binding of $\left[{ }^{3} \mathrm{H}\right]$ rauwolscine and $\left[{ }^{3} \mathrm{H}\right] \mathrm{RX} 821002$ to the alpha-2 adrenergic receptor subtypes. J. Pharm. Exp. Therap. 278: 1215-27. 1996. 
Durham JP, Butcher FR, Teoh TS, Miller R, Mawhinney MG: Characterization and androgenic regulation of soluble protein kinases and protein phosphorylation in rat ventral prostate gland. Arch. Biochem Biophys. 244 : 692-700. 1986 .

Durham J, Galanti N, Pevis N: The purification and characterization of plasma membranes and the subcellular distribution of adenylate cyclase in mouse parotid gland. Biochem. Biophys. Acta 394: 388-40. 1975.

Ekman P: BPH epidemiology and risk factors. Prostate [Suppl] 2:23-31, 1989 .

English HF, Drago JR, Santen RJ: Cellular response to androgen depletion and repletion in the rat ventral prostate: autoradiography and morphometric analysis. Prostate 7: 41-51. 1985.

Erdbrugger $W$, Raulf $M$, Otto $T$, Michel MC: Does $\left[{ }^{3} \mathrm{H}\right] 2-$ methoxy-idazoxan ( $R X$ 821002) detect more alhpa-2adrenoceptor agonist high-affinity sites than $\left[{ }^{3} \mathrm{H}\right]$ rauwolscine? A comparison of nine tissues and cell lines. J. Pharm. And Exp. Therap. 273: 1287-94. 1995.

Erlinge D, Yoo H, Edvinson L, Reis DJ, Wahlestedt C: Mitogenic effects of ATP on vascular smooth muscle cells versus other growth factors and sympathetic cotransmitters. Amer. J. Physiol. 265: 1089-97. 1993.

Farnsworth WE and Brwon JR: Testosterone metabolism in the prostate. Nat. Cancer Inst. Monogr. 12: 323. 1963.

Feige JJ, Bradley JD, Frybyrg K, Farris J, Cousens LC, Barr PJ, Baird A: The differential effects of heparin, fibronectin, and laminin on the phosphorylation of basic fibroblast growth factor by protein kinase $C$ and the catalytic subunit of protein kinase A. J. Cell Biol. 109: 3105-14. 1989.

Fingerhut B and Veenema R: Histology and radioautography of induced benign enlargement of the mouse prostate. Invest. Urol. 4: 112-24. 1966. 
Fingerle J, Sanders KH, Fotev Z: Alpha 1-receptor antagonists urapidil and prazosin inhibit neointima formation in rat carotid artery induced by balloon catheter injury. Basic Research in Cardiology. 86: Supplement 1: 75-81. 1991.

Franks L: Benign prostatic hyperplasia: gross and microscopic anatomy in benign prostatic hyperplasia. Grayhack, et. al., DHEW publication \#(NIH)76-1113, 63 . 1975.

Fritze LMS, Reilly CF, Rosenberg RD: An antiproliferative heparan sulfate species produced by postconfluent smooth muscle cells. J. Cell Biol. 100: 1941-9. 1985.

Geller J: Effect of finasteride, a $5 \alpha$-reductase inhibitor on prostate tissue androgens and prostate-specific antigen. J. Clin. Endo. Metab. 71: 1552-55. 1990.

Geller J, Kirschenbaum A, Lepor H, Levine AC: Therapeutic controversies: clinical treatment of benign prostatic hyperplasia. J Clin Endocrinol Metabol 80:745-56, 1995.

Gerbrosky N, Cole D, Stetter-Neel C, Durham J, Mawhinney M: m-Calpain activation/depletion is associated with androgen-induced reduction of protein kinase $\mathrm{C}$ and proliferation of male accessory sex organ smooth muscle cells. J. Urology 157: 662-8. 1997.

Getzenberg RH, Pienta KJ, Huang EY, Murphy BC, Coffey DS: Modifications of the intermediate filament and nuclear matrix networks by the extracellular matrix. Biochem. Biophys. Res. Commun. 179: 340-4. 1991.

Giachetti A, Shore PA: The reserpine receptor. Life Sciences 23: 89-92. 1978.

Glynn RJ, Campion EW, Bouchard GR, Silbert JE: The development of benign prostatic hyperplasia among volunteers in the Normative Aging Study. Am J Epidemiol 121:78-90, 1985 . 
Goncalves J, Dreissen B, von Kugelgen I, and Starke K: Comparison of corelease of noradrenaline and ATP evoked by hypogastric nerve stimulation and field stimulation in guinea pig vas deferens. Naunyn-Schmeid. Arch. Pharmacol. 352: 229-35. 1995.

Graefe KH, Stefano FJE, Langer SZ: Preferential metabolism of $(-)-{ }^{3} \mathrm{H}$-norepinephrine through the deaminated glycol in the rat vas deferens.

Biochem. Pharm. 22: 1147-60. 1973.

Graversen PH, Gasser TC, Wasson JH, Hinman F, Bruskewitz $\mathrm{RC}$ : Controversies about indications for transurethral resection of the prostate. J Urol 141: 475-481, 1989.

Haller H, Lindschau C, Quass P, Distler A, Luft FC: Differentiation of vascular smooth muscle cells and the regulation of protein kinase $\mathrm{C}-\alpha$. Circulation Research. 76: 21-29. 1995.

Hammond GL: Endogenous steroid levels in the human prostate from birth to old age: a comparison of normal and diseased tissues. J. Endocrin. 78: 7-19. 1978.

Hannun YA, Loomis CR, Merrill AH, Bell RM: Sphingosine inhibition of protein kiase $\mathrm{C}$ activity and of phorbol dibutyrate binding in vitro and in human platelets. J. Biol. Chem. 261:12604-9. 1986.

Hansen K, Monteiro-Riviere N, Smart RC: Differential downregulation of epidermal protein kinase C by 12-0tetradecanoylphorbol-13-acetate and diacylglycerol: association with epidermal hyperplasia and tumore promotion. Cancer Res. 50: 5740. 1990.

Hauss WH, Bauch HJ, Schulte H: Adrenaline and noradrenaline as possible chemical mediators in the pathogenesis of arteriosclerosis. Annals NY Academy of Sciences. 598: 91-101. 1990.

Hein M, Fischer J, Kim DK, Hein L, Pratt RE: Vascular smooth muscle cell phenotype influences glycosaminoglycan composition and growth effects of extracellular matrix. J. Vasc. Res. 33: 433-41. 1996. 
Henrich CJ, Simpson PC: Differential acute and chronic response of protein kinase $\mathrm{C}$ in cultured neonatal rat heart myocytes to alpha 1-adrenergic and phorbol ester stimulation. Journ. Mol. and Cell. Cardiology. 20: 1081-1085. 1988 .

Herbert JM and Maffrand JP: Effect of pentosan polysulfate, standard heparin and related compunds on protein kinase C activity. Biochim. Biophys. Acta. 1091: 432-41. 1991 .

Hu Z, Azhar S, Hoffman BB: Prolonged activation of $\alpha_{1}$ adrenoceptors induces down-regulation of protein kinase $\mathrm{C}$ in vascular smooth muscle. Journ. of Cardiovasc. Pharmacology. 20: 982-989. 1992 .

Huggins C: Prostatic secretion. Harvey Lectures 42: 148 . $1946-7$.

Huggins $C$ and Stevens R: The effects of castration on benign hypertrophy of the prostate in man. J. Urol. 43: 705-14. 1940 .

Isaacs JT, Coffey DS: Etiology and disease process of benign prostatic hyperplasia. Prostate [Suppl]2:3350,1989 .

Johnson EA, Centenera V, Cole D, Kim J, Durham J, Azzaro A, Fedan J, Mawhinney M: Androgen-induced norepinephrine release is coupled to protein kinase $C$ (PKC) and postnatal growth and differentiation of male accessory sex organ smooth muscle (Abstract). J. Urol. [Suppl] 155: 463A. 1996.

Jonler M, Riehmann M, Bruskewitz RC: Benign prostatic hyperplasia: current pharmacological treatment. Drugs $47: 66-81,1994$.

Josefsson E, Bergquist J, Ekman R, Tarkowski A: Catecholamines are synthesized by mouse lymphocytes and regulate function of these cells by induction of apoptosis. Immunology 88: 140-6. 1996.

Jost A: Problems of fetal endocrinology: the gonadal and hypophyseal hormones. Recent Prog. Horm. Res. 8: 379413. 1953. 
Jung-Testas I, Hu ZY, Baulieu EE, Robel P: Neurosteroids: Biosynthesis of pregnenolone and progesterone in primary cultures of rat glial cells. Endocrinology 125: 2038. 1989.

Kikuchi H, Imajoe-Ohmi S: Antibodies specific for proteolyzed forms of protein kinase C alpha. Biochem. Biophys. Acta. 1269: 253-259. 1995.

Kirkpatrick K, Burnstock G: Sympathetic nerve-mediated release of ATP from the guinea-pig vas deferens is unaffected by reserpine. Eur J Pharmacol 138: 207-14. 1987.

Kishimoto A, Takai Y, Mori T, Kikkawa U, and Nishizuka Y: Activation of calcium and phospholipd-dependent protein kinase by diacylglycerol, its possible relation to phsphatidylinositol turnover. J. Biol. Chem. 255: 2273-6. 1980 .

Kohnen PW, Drach GW: Patterns of inflammation in prostatic hyperplasia: a histologic and bacteriologic study. J Urol 121:755-60, 1979 .

Kolesnick RN: 1,2-diacylglycerols but not phorbol esters stimulate sphingomyelin hydrolysis in GH3 pituitary cells. J. Biol. Chem. 262: 16759-62. 1987.

Kraft AS and Anderson WB: Phorbol esters increase the amount of $\mathrm{Ca}^{2+}$, phospholipid-dependent protein kinase associated with plasma membrane. Nature 301: 621-3. 1983.

Krieg M, Dennis M, Voight KD: Comparison between binding of 19-nortestosterone, 5alpha-dihydrotestosterone and testosterone in rat prostate and bulbocavernosus/levator ani muscle. J. Endocrinol. 70: $379-87.1976$.

Langer SZ, Enero MA: The potentiation of responses to adrenergic nerve stimulation in the presence of cocaine: Its relationship to the metabolic fate of released norepinephrine. J. Pharm. Exp. Therap. 191: 431-43. 1974 . 
Langer SZ, Massingham R, Shepperson NB: Presence of postsynaptic $\alpha_{2}$-adrenoceptors of predominantly extrasynaptic location in the vascular smooth muscle of the dog hind limb. Clin. Sci. 59: 225-8. 1980.

LaPierre N, Wilson J, Bourreau JP, Tougas G, Kwan CY, Daniel EE: Norepinephrine release in rat vas deferens: Effect of rauwolscine and BHT 920. Life Sciences 53: 19-24. 1993.

Larsson B, Hogestatt ED, Mattiasson A, Andersson KE: Differential effects of nifedipine, verapamil, and diltiazem on noradrenaline-induced contractions, adrenergic transmitter release, and alpha-adrenoceptor binding in the female rabbit urethra.

Naunyn Schmiedebergs Arch Pharmacol. 326: 14-21. 1984.

Lepor H, Williford WO, Barry MJ, Brawer MK, Dixon CM, Gormley G, Haakenson C, Machi M, Narayan P, Padley RJ: The efficacy of terazosin, finasteride, or obth in benign prostatic hyperplasia. New Engl. J. Med. 335: 533-9. 1996.

Levey HA and Szego, C.M.: Metabolic characteristics of the guinea pig seminal vesicle. Am. J. Physiol. 182: 507512. 1955 .

Liao $S$ and Fang $S$ : Receptor-proteins for androgens and the mode of action of androgens on gene transcription in ventral prostate. Vitam. Horm. 27: 17-90. 1970.

Lindzey J, Kumar MV, Grossman M, Young C, Tindall DJ: Molecular mechanisms of androgen action. Vitam Horm $49: 383-432,1994$.

Lockshin RA, Beaulaton J: Programmed cell death. Cytochemical evidence for lysosomes during the normal breakdown of the intersegmental muscles. J. Ultrastruct. Res. 46: 43-62. 1974.

Lubahn DB, Joseph DR, Sullivan PM: Cloning of human androgen receptor complementary DNA and localization to the $\mathrm{X}$ chromosome. Science 240: 327-330, 1988 .

Lytton B, Emery JM, Harvard BM: The incidence of benign prostatic obstruction. J Urol 99:639-45, 1968. 
MacDonald A, McGrath JC: Post-natal development of functional neurotransmission in rat vas deferens. Brit. J. Pharmac. 82: 25-34. 1984 .

MacDonald A, McGrath JC: The distribution of adrenoceptors and other drug receptors between the two ends of the rat vas deferens as revealed by selective agonists and antagonist. Br. J. Pharmac. 71: 445-458. 1980.

Mahesh VB, Brann DW, Hendry LB: Diverse modes of action of progesterone and its metabolites. J. Ster. Biochem. Mol. Biol. 56: 209-19. 1996.

Maini A, Archer C, Wang CY, Haas GP: Comparative pathology of benign prostatic hyperplasia and prostate cancer. In Vivo. 11: 293-300. 1997.

Marino TA, Walter RA, D'Ambra $K$, Mercer WE: Effects of catecholamines on fetal rat cardiocytes in vitro. Amer. Journ. of Anatomy. 186: 127-132. 1989.

Mariotti A and Mawhinney M: Hormonal control of accessory sex organ fibromuscular stroma. Prostate 2: 397-408. 1981 .

Mariotti A, Durham J, Mawhinney M: Protein kinases and the androgen-induced proliferation of accessory sex organ smooth muscle. Biol. of Reproduction. 46: 551560. 1992 .

Melcangi RC, Celotti F, Ballabio M, Poletti A and Martini L: Testosterone metabolism in peripheral nerves: Presence of the 5 alpha-reductase-3-alphahydroxysteroid-dehydrogenase enzymatic system in the sciatic nerve of adult and aged rats. J. Steroid Biochem. 35: 148. 1990.

Meldrum LA, Burnstock G: Evidence that ATP is involved as the co-transmitter in the hypogastric nerve supplying the seminal vesicle of the guinea-pig. Euro. J. Pharmac. 110: 363-366. 1985.

MCNeal JE: Origin and evolution of benign prostatic enlargement. Invest Urol 15:340-345. 1978 . 
Mimura Y, Kobayashi S, Notoya K, Okabe M, Kimura I, Horikoshi I, Kimura M: Activation by alpha 1adrenergic agonists of the progression phase in the proliferation of primary cultures of smooth muscle cells in mouse and rat aorta. Biol. Pharm. Bull. 18: 1373-1376. 1995.

Miralles A, Olmos G, Sastre M, Barturen F, Martin I, Garcia-Sevilla JA: Discrimination and pharmacological characterization of $\mathrm{I}_{2}$-imidazoline sites with $\left[{ }^{3} \mathrm{H}\right]$ idazoxan and alpha-2 adrenoceptors with $\left[{ }^{3} \mathrm{H}\right] \mathrm{RX821002}$ (2-methoxy idazoxan) in the human and rat brains. Journ. Pharmac. Exp. Therap. 264: 1187-97. 1993.

Mochly-Rosen D, Khaner H, Lopez J, Smith BL: Intracellular receptors for activated protein kinase C: Identification of a binding site for the enzyme. J. Biol. Chem. 266: 14866-8. 1991 .

Moore RA: Benign hypertrophy and carcinoma of the prostate: occurrence and experimental production in animals. Surgery 16: 152-67. 1944.

Nakaki $T$, Nakayama M, Yamamoto $S$, Kato R: Alpha 1adrenergic stimulation and beta 2-adrenergic inhibition of DNA synthesis in vascular smooth muscle cells. Mol. Pharm. 37: 30-36. 1990.

Neubauer BL, Biser P, Jones CD, Mariotti A, Hoover DM, Thornton $\mathrm{T}$, Thornton MO, Goode RL: Antagonism of androgen and estrogen effects in guinea pig seminal vesicle epithelium and fibromuscular stroma by keoxifene. Prostate 15: 273-86. 1989.

Neubauer BL, Mawhinney MG: The action of androgens and estrogens on guinea pig seminal vesicle epithelium and muscle. Endocrinology 108: 680-7. 1981.

Neubauer B, Blume C, Cricco R, Greiner J, Mawhinney M: Comparative effects and mechanisms of castration, estrogen, anti-androgen, and anti-estrogen-induced regression of accessory sex organ epithelium and muscle. Invest. Urol. 18: 229-34. 1981. 
Nielsen H, Thom SMCG, Hughes AD, Martin GN, Mulvany MJ, Sever PS: Postjunctional $\alpha_{2}$-adrenoceptors mediate vasoconstriction in human subcutaneous resistance vessels. Br. J. Pharmacol. 97: 829-34. 1989.

Nishi $N$, Oya $H$, Matsumoto $K$, Nakamura $T$, Miyanaka $H$, Wada F: Changes in gene expression of growth factors and their receptors during castration-induced involution and androgen-induced regrowth of rat prostates. Prostate 28: 139-152. 1996.

Oesterling JE: The Urolume ${ }^{\mathrm{TM}}$ endoprosthesis: a summary of the European and North American experience. Benign Prostatic Hyperplasia. 561-575. 1994.

Oesterling JE: Benign prostatic hyperplasia. N Engl J Med 332:99-109, 1995

O'Roarke MF, Blaxall HS, Iverson LJ, Bylund DB:

Characterization of $\left[{ }^{3} \mathrm{H}\right] \mathrm{RX} 821002$ binding to alpha-2 adrenergic receptor subtypes. J. Pharmacol. Exp. Therap. 268: 1362-1367. 1994 .

Palfai T, Wichlinski L, Brown HA, Brown OM: Effects of amnesic doses on reserpine of syrosingopine on mouse brain acetylcholine levels.

Pharmacol. Biochem. Behav. 24: 1457-9. 1986.

Pears CJ, Parker PJ: Domain interactions in protein kinase C. Journ. Cell Sci. 100: 683-686. 1991.

Pradhan BK and Chandra K: Morphogenesis of nodular hyperplasia in the prostate. J. Urol. 113: 210-213. 1975 .

Price D and Williams-Ashman HC: In Sex and Internal Secretion, (WC Young, ed.), $3^{\text {rd }}$ ed., Vol.1., pp. 366448. Williams \& Wilkins, Baltimore, MD. 1961.

Rago R, Mitchen J, Wilding G: DNA fluorometric assay in 96well tissue culture plates by freezing in distilled water. Analytical Biochem. 191: 31-34. 1990. 
Refsnes M, Thoresen GH, Sandnes D, Dajani OF, Dajani L, and Christofferson $\mathrm{T}$ : Catecholamines on DNA synthesis in primary rat hepatocyte cultures: role of alpha 1- and beta-adrenergic mechanisms.

Journ. of Cell. Physiol. 151: 164-171. 1992.

Reischauer S: Die entstenhung der sogenannten prostatahypertrophie. Virchows Arch, (Pathol. Anat. Physiol.) 256: 357-89. 1925.

Revelli A, Massobrio M, Tesarik J: Nongenomic actions of steroid hormones in reproductive tissues. Endo. Rev. 19: 3-17. 1998 .

Rohr HP, Bartsch G: Human benign prostatic hyperplasia: a stromal disease? New perspectives by quantitative morphology. Urology. 16: 625-633. 1980 .

Rouhi AM: Crystal structure sheds light on binding of tumor promotors to key enzyme.

C. and EN: 21-5. 1995.

Roy AK and Chatterjee B: Androgen action. Crit. Rev. Eukaryot. Gene Expr. 5: 157-76. 1995.

Sasaguri T, Kosaka C, Hirata M, Masuda J, Shimokado K, Fujishima $\mathrm{M}$, Ogata $\mathrm{J}$ : Protein kinase $\mathrm{C}$-mediated inhibition of vascular smooth muscle cell proliferation: the isoforms that may mediate $\mathrm{G}_{1} / \mathrm{S}$ inhibition. Experimental Cell Research. 208: 311320. 1993.

Schipper DL, Wagenmans MJM, Peters WHM, Wagener DJT: Significance of cell proliferation measurement in gastric cancer. Euro. J. Cancer 34: 781-90. 1998.

Simanis V, Nurse P: The cell cycle control gene cdc2t of fission yeast encodes a protein kinase potentially regulated by phosphorylation. Cell 45: 261-8. 1986.

Simmonneaux V, Ebadi M, Bylund DB: Identification and characterization of the alpha ${ }_{2 D}$-adrenergic receptors in bovine pineal gland.

Mol. Pharmacol, 40: 235-41. 1991. 
Sneddon P, Westfall DP, Fedan JS: Cotransmitters in the motor nerves of the guinea pig vas deferens: electrophysiological evidence. Science 218: 693-5. 1982.

Sutkowski DM, Kasjanski RE, Sensibar JA, Ney KG, Lim DJ, Kozlowski JM, Lee C, Grayhack JT: Effect of spermatocele fluid on growth of human prostatic cells in culture. J Androl 12:223-239, 1993.

Swedin G: Postnatal development of the mechanical response of the isolated vas deferens to nerve stimulation. Acta Physiol. Scand. 84: 217-223. 1972.

Talalay P, Williams-Ashman HG: Activation of hydrogen transfer between pyridine nucleotides by steroid hormones. Proc. Natl. Acad. Sci. 44: 15-26. 1958.

Tarlov SR, Langer SZ: The fate of ${ }^{3} \mathrm{H}$-norepinephrine released from isolated atria and vas deferens: Effect of field stimulation. J. Pharm. Exp. Therap. 179: 186-97. 1971.

Tatton NA, Maclean-Fraser A, Tatton WG, Prel DF, and Olanow CW: A fluorescent double-labeling method to detect and confirm apoptotic nuclei in Parkinson's disease. Ann. Neuro. 44: S142-S148., 1998.

Timmermans PBMWM, van Zwieten PA: Postsynaptic $\alpha_{1}-$ and $\alpha_{2}-$ adrenoceptors in the circulatory system of the pithed rat: selective stimulation of the $\alpha_{2}$-subtype by BHT 933. Eur. J. Pharmacol. 63: 199-202. 1980.

Vauquelin G, de Vos H, de Backer JP, Ebinger G: Identification of $\alpha_{2}$ adrenergic receptors in human frontal cortex membranes by binding of $\left[{ }^{3} \mathrm{H}\right] \mathrm{RX} 821002$, the 2-methoxy analog of $\left[{ }^{3} \mathrm{H}\right]$ idazoxan. Neurochem. Int. 17: $537-46.1990$.

Ventura S, Hoyle CV, Burnstock G: Sodium nitroprusside enhances contractions of the guinea-pig isolated vas deferens. J Pharm Pharmacol 50: 205-9. 1998.

Walsh PC: Experimental approaches to benign prostatic hypertrophy: animal models utilizing the dog, rat and mouse. DHEW Publ. NIH washington DC 76-1113, 215-22. 1976. 
Watson $\mathrm{MH}$, Venance SL, Pang SC, Mak AS: Smooth muscle cell proliferation: Expression and kinase activities of p34 ${ }^{\text {cdc2 }}$ and mitogen-activated protein kinase homologues. Circ. Res. 73: 109-17. 1993.

Wenderoth UK, George FW, and Wilson JD: The effect of a $5 \alpha-$ reductase inhibitor on androgenimediated growth of the dog prostate. Endocrinology 113: 569-73. 1983.

Westfall DP, McClure DC, Fleming WW: The effects of denervation, decentralization and cocaine on the response of the smooth muscle of the guinea pig vas deferens to various drugs.

Journ. Pharm. and Experimental Therapeutics. 181: 328-338. 1972 .

Westfall DP, Stitzel RE, Rowe JN: The postjunctional effects and neural release of purine compounds in the guinea pig vas deferens. Eur. J. Pharmacol, 50: 2738. 1978 .

White JW: The present position of surgery of the hypertrophied prostate. Ann Surg 18: 152, 1893.

Wu JP, Gu FL: The prostate 41-65 years post-castration: an analysis of 26 eunichs. Chin Med J [Engl] 100: 271$272,1987$.

Wyllie AH: Glucocorticoid-induced thymocyte apoptosis is associated with endogenous endonuclease activation. Nature 284: 555-6. 1980 .

Young S, Parker PJ, Ullrich A, Stabel S: Down-regulation of protein kinase $\mathrm{C}$ is due to an increased rate of degradation. Biochem. Journ. 244: 775-779. 1987.

Zhang YQ, Kanzaki M, Mashima H, Mine T, Kojima I: Norepinephrine reverses the effects of activin $A$ on DNA synthesis and apoptosis in cultured rat hepatocytes.

Hepatology 23: 288-293. 1996. 
Education:

\section{Curriculum Vitae}

Currently in a joint MD/PhD program. West Virginia University School of Medicine.

May 1999: PhD in Pharmacology

May 2001: MD expected.

1995: Awarded the Korean-American Medical Association Medical student Fellowship

Masters in Fine Arts (Creative Writing). Brown University, Providence, RI. May 1993.

Awarded a University Fellowship 1991.

Masters thesis: "N=1": A Yellow Girl in Appalachia. A collection of short stories and poetry. Awarded the Rose Lowe Rome Award for best manuscript, 1993.

Wesleyan University, Middletown, CT. BA in English, Magna cum laude, May 1991.

Honors thesis awarded Best Manuscript, 1991.

Phillips Exeter Academy (prep school), Exeter, NH. Graduated May 1987.

\section{Research:}

Studied the role of norepinephrine release in androgen-dependent accessory sex organ smooth muscle proliferation and differentiation using the guinea pig seminal vesicle as a model for human benign prostatic hypertrophy. Worked under the supervision of Michael Mawhinney, Ph.D., Professor of Pharmacology and Toxicology with an appointment in the Dept. of Urology, West Virginia University School of Medicine.

\section{Presentations :}

March 1996: Poster at the International Symposium on the Biology of the Prostate, Washington, D.C., sponsored by the NIH

May 1996: Poster at the American Urologic Association, Orlando, FL., sponsored by the AUA.

May 1996: Poster at the Pfizer Pharmaceuticals Research Evening, Orlando, FL, sponsored by Pfizer Pharmaceuticals.

March 1997: Poster at West Virginia University School of Medicine Research Day.

July 1997: Poster at the National Student MD/PhD conference, Aspen, CO.

March 1999: Presentation at West Virginia University School of Medicine Van Liere Convocation.

March 1999: Poster at West Virginia University School of Medicine Research Day. 


\section{Teaching Experience:}

Assistant Professor of Creative Writing. Brown University. September 1992-May 1993.

Had full responsibility of teaching from planning syllabi, conferences, and grade determination.

Lecturer for Nursing Pharmacology. West Virginia University School of Medicine. Spring 1997 and 1998. Lectures on Asthma Therapy and Fertility.

Teaching Assistant for Medical Pharmacology. West Virginia University School of Medicine. Spring 1996 and 1998. Led weekly Problem Based Learning sessions for 10-12 medical students.

\section{Extracurricular Activities :}

Mother of 1 and 2 year old daughters. Duties include everything possible 24 hours per day, seven days per week, 52 weeks per year.

Search Committee Member for the Chair of the Dept. of Pharmacology and Toxicology, West Virginia University, School of Medicine. December to July 1999.

Student MD/PhD representative. West Virginia University School of Medicine. July 1996-November 1997. Scheduled meetings and speakers as well as represented the students in administrative meetings.

Counselor. Rape and Domestic Violence Information Center, Morgantown, WV. July 1995-February 1997.

Duties included meeting victims at emergency rooms and police stations, as well as crisis intervention by telephone.

Volunteered 40 hours per month.

Editor-in-Chief. The Bedpan: Modern Movements in Medicine. West Virginia University School of Medicine monthly student newspaper. April 1994-April 1995. Supervised and delegated all tasks necessary to publish a newspaper from assigning articles to lay-out and finance.

Articles Editor. The Bedpan. August 1993-March 1994. Student Academic Committee. West Virginia University School of Medicine. September 1993-May 1995. Elected to 2 consecutive terms to represent medical students in academic issues ranging from curriculum to exam scheduling. 